\title{
ANTIBODIES AND AUTOIMMUNE DISEASES IN RELATION TO REPRODUCTIVE FAILURES
}

Mónika Kovács MD. PhD Thesis

2014. 


\title{
ANTIBODIES AND AUTOIMMUNE DISEASES IN RELATION TO REPRODUCTIVE FAILURES
}

\author{
Mónika Kovács MD. \\ PhD Thesis
}

\author{
Obstetrics and Gynecology Department \\ Albert Szent-Györgyi Clinical Center \\ University of Szeged, Faculty of Medicine
}

Supervisor: Prof. György Bártfai MD, PhD, DSc

Med. Habil. Beáta Gasztonyi MD, PhD

2014. 


\section{PUBLICATIONS RELATED TO THE SUBJECT OF THE THESIS}

\section{Papers}

I. Kovacs M., Farkas A., Gyorkos A., Hartwig M., Aleksza M., Tihanyi M., Nagy T., Gasztonyi B.: Antibodies and autoimmune diseases present in sterile and infertile females. Magyar Belorv. Arch., 61. (5), 395-399., 2008.

II. Kovacs M., Hartwig M., Aleksza M., Tihanyi M., Nagy T., Gasztonyi B.: Searching for autoimmune diseases in sterile/infertile couples. Magyar Reumatol., 50. (4), 196202., 2009.

III. Kovacs M., Szenes M., Horvath T., Vajda Gy., Gasztonyi B.: Celiac disease in the background of reproductive disorders. Magyar Belorv. Arch., 64. (4), 225-230., 2011.

IV. Kovacs M., Hartwig M., Aleksza M., Tihanyi M., Nagy T., Vajda Gy., Daru J., Gasztonyi B.: Antiphospholipid antibodies in relation to sterility/infertility. Human Immunology, 73., 726-731., 2012.

IF: $\mathbf{2 . 8 3 7}$

V. Kovacs M., Farkas A., Hartwig M., Aleksza M., Tihanyi M., Nagy T., Gasztonyi B.: Antibodies and autoimmune diseases in the background of sterility/infertility. Magyar Belorv. Arch., Suppl., 61. (3), 76-77., 2008.

VI. Kovacs M., Farkas A., Gyorkos A., Hartwig M., Aleksza M., Tihanyi M., Nagy T., Gasztonyi B.: Antiphospholipid syndrome in the background of sterility/infertility. Magyar Belorv. Arch., Suppl., 62. (1), 39., 2009.

VII. Kovacs M., Szenes M., Gasztonyi B.: Celiac disease in the background of reproductive disorders. Magyar Belorv. Arch., Suppl., 62. (2), 73., 2010.

VIII. Kovacs M., Vajda Gy., Gasztonyi B.: Pregnancy - Be in a delicate condition? Autoimmune diseases in relation to pregnancy. Magyar Belorv. Arch., Suppl., 64. (1), 45., 2011.

IX. Kovacs M., Szenes M., Horvath T., Vajda Gy., Gasztonyi B., Bartfai Gy.: Celiac disease as potential obstacle to childbearing. OJOG, 4., 2014., accepted 


\section{PUBLICATIONS NOT RELATED TO THE SUBJECT OF THE THESIS}

\section{Papers}

I. Kovacs M., Hafner J., Gabor V., Sipos J.: Successful treatment of Weber-Christian panniculitis with cyclosporin-A. Orv. Hetil., 145. (15), 827-831., 2004.

II. Jajic Z., Malaise M., Nekam K., Koo E., Danko K., Kovacs M., Scarpignato C.: Gastrointestinal safety of amtolmetin guacyl in comparison with celecoxib in patiens with rheumatoid arthritis. Clin. Exp. Rheumatol. 23. (6), 809-818., 2005.

IF: 2.4

III. Bolf Zs., Kovacs M., Lupkovics G.: Myocardial infarction in systemic lupus erythematosus. Lege Artis Medicinae, 21. (2), 143-146., 2011.

IV. Kovacs M., Hafner J.: Intravenous immunoglobulin treatment on our department. Magyar Belorv. Arch., Suppl., 53. (1), 53., 2000.

V. Kovacs M., Hafner J.: Intravenous immunoglobulin treatment on our department. Magyar Belorv. Arch., Suppl., 53. (3), 107., 2000.

VI. Kovacs M., Hafner J.: Weber-Christian syndrome. Magyar Reumatol., 42. (3), 172173., 2001.

VII. Kovacs M., Sipos J., Hafner J.: Retroperitoneal fibrosis. Magyar Belorv. Arch., Suppl., 55. (1), 63., 2002.

VIII. Kovacs M., Sipos J., Hafner J.: Retroperitoneal fibrosis. Magyar Belorv. Arch., Suppl., 55. (3), 86-87., 2002.

IX. Kovacs M., Hafner J., Sipos J., Gyorkos A.: Coexistence of Polymyositis and Polyarteritis nodosa. Magyar Belorv. Arch., Suppl., 56. (2), 71., 2003.

X. Kovacs M., Sipos J., Tarnok F.: Interesting case of Schwannoma with paraneoplastic myositis. Magyar Belorv. Arch., Suppl., 57. (1), 2004.

XI. Kovacs M., Szekeres I., Toth Z., Tarnok F.: Consequence of the piroxicam treatment: Toxic epidermal necrolysis (Lyell syndrome). AKI, 9. (3), 106., 2006.

XII. Kovacs M., Suto G., Czirjak L., Tarnok F.: Patient with Juvenile idiopathic arthritis suffered from Systemic lupus erythematosus in adulthood. Magyar Reumatol., 47. (3), 156., 2006.

XIII. Kovacs M., Szekeres I., Toth Z., Gasztonyi B.: Consequence of the piroxicam treatment: Toxic epidermal necrolysis (Lyell syndrome). Magyar Reumatol., 48. (2), 117-118., 2007. 
XIV. Kovacs M., Gasztonyi B.: Rheumatic fever and „rheumatic nephritis”. Magyar Belorv. Arch., Suppl., 60. (1), 38., 2007.

XV. Farkas A., Kovacs M., Gasztonyi B.: Differencial diagnostic problems of asymmetric oligoarthritis on the department of Internal Medicine - a concrete case. Magyar Belorv. Arch., Suppl., 60. (1), 27., 2007.

XVI. Farkas A., Kovacs M., Gasztonyi B.: Infection of Neisseria gonorrhea with oligoarthritis. Magyar Reumatol., 48. (3), 173., 2007.

XVII. Bodorkos I., Aleksza M., Horvath E., Dancza T., Farkas A., Gyorkos A., Kovacs M., Tiboly M., Toth P., Gasztonyi B.: Haemotherapy and its serological aspects of patients suffering from immunohaematological diseases. Blood Reviews, Suppl., 21, 119., 2007.

IF: $\mathbf{5 . 9 2 2}$

XVIII. Farkas A., Kovacs M., Gyorkos A., Milics M., Nagy Gy., Tarnok F.: Serious clinical manifestations of Systemic lupus erythematosus - case report. Magyar Belorv. Arch., Suppl., 61. (3), 2008.

XIX. Kovacs M., Fatalin K., Kiss K., Lazanyi-Bacso I., Somogyi R., Rashed A., Nik1 J., Mahr K., Hohl Gy., Nagy Gy., Szalczer L., Gasztonyi B.: Internal Medicine taking service with other medical discipline as the success of interdisciplinal approach in the cure. Magyar Belorv. Arch. Suppl., 66. (1), 41., 2013.

\section{Cummulative impact factor: 11.159}




\section{CONTENTS}

$\begin{array}{ll}\text { Abbreviations } & 7\end{array}$

Introduction

1. Antibodies and systemic autoimmune diseases - especially antiphospholipid syndrome - in relation to reproductive failures

2. Autoimmune thyroiditis and thyroid dysfunction in relation

to reproductive failures

3. Celiac disease in relation to reproductive failures

4. Anti-sperm antibody in relation to reproductive failures

Aims of the investigation

Patients and methods

I. Antiphospholipid antibodies and antiphospholipid syndrome in relation to reproductive failures

II. Antibodies of the systemic autoimmune diseases in relation to reproductive failures

III. Autoimmune thyroiditis and thyroid dysfunction in relation to reproductive failures

IV. Celiac disease in relation to reproductive failures

Discussion

New observation

Acknowledgments

Összefoglalás

References 


\section{ABBREVIATIONS}

AB: abortion

aCL: anticardiolipin antibody

ANA: antinuclear antibody

anti-dsDNA: anti-double-stranded DNA antibody

anti-Jo-1: anti-histidyl-tRNA synthetase antibody

anti-RNP: anti-ribonucleoprotein antibody

anti-Sm: antibody to Sm-proteins

anti-SS-A: antibody to 3-component non-histone proteins

anti-SS-B: antibody to phosphoprotein of RNA-polimerase III cofactor

anti-tTG: anti-tissue-transglutaminase antibody

anti-TPO: anti-thyroid peroxidase antibody

aANX: anti-Annexin V antibody

aPLs: antiphospholipid antibodies

aPS: anti-phosphatidyl serine antibody

aPE: anti-phosphatidyl ethanolamine antibody

aPT: anti-prothrombin antibody

aß2GPI: anti-beta-2 glycoprotein I antibody

APS: antiphospholipid syndrome

a-sperm: anti-sperm antibody

ASA: acetylsalicylic acid

ADHD: attention-deficit hyperactivity disorder

BMI: body-mass index

$\beta_{2}$ GPI: $\beta_{2}$ glycoprotein I

CAPS: catastrophic antiphospholipid syndrome

CD: celiac disease

$\mathrm{DAF} / \mathrm{CD} 55$ : complement regulatory proteins

ENA-Profile: antibodies against extractable nuclear antigens

ELISA: enzyme-linked immunosorbent assay

Fe: iron

FT3: free tri-jodide-thyronine

FT4: free thyroxin

GPL: IgG phospholipid level 
g: gramme

h: hour

HB-EGF: heparin-binding epidermal growth factor

hCG: human chorionic gonadotrophin

Hgb: hemoglobin

Htc: hematocrit

IF: immunofluorescent method

if: infertile

IgA: immunoglobulin A

IgE: immunoglobulin $\mathrm{E}$

IgG: immunoglobulin $\mathrm{G}$

IgM: immunoglobulin $\mathrm{M}$

insem: insemination

IU: international unit

IUGR: intrauterine growth retardation

IVF: in vitro fertilization

IVIG: intravenous immunoglobulin

Kg: kilogramme

LA: lupus anticoagulant

L: litre

LMWH: low molecular weight heparin

$\mathrm{mL}$ : millilitre

mg: milligramme

mU: milliunit

MPL: IgM phospholipid level

$\mu$ mol: micromol

$\mu \mathrm{g}$ : microgramme

ng: nanogramme

$\mathrm{N}$ : number of patients

PAP: placental anticoagulant proteins

PAPS: primary antiphospholipid syndrome

pg: pikogramme

pmol: pikomol

SAPS: secondary antiphospholipid syndrome 
SLE: systemic lupus erythematosus

sp: spontaneous

st: sterile

TSH: thyroid-stimulating hormone

UFH: unfractionated heparin

$\mathrm{U}$ : unit

W: week of gestation 


\section{INTRODUCTION}

Autoantibodies, autoimmune conditions are frequent causes underlying unsuccessful attempts for having a child. In a significant part of cases these are not recognised as the affected women have usually no other signs or symptoms suggesting an autoimmune disease.

A couple is considered sterile if there is a complete inability to conceive or produce an offspring. The infertility definied by the absence of conception after 24 months of regular, unprotected intercourse (1). Of couples in reproductive age, 8 to $10 \%$ are sterile and 15 to $20 \%$ are infertile. Various genetic, hormonal, gynaecological, andrological, and immunological factors may underlie both conditions, but in about 10 to $20 \%$ of cases there is no detectable cause (2). In sterile/infertile (st/if) female patients auto-antibodies may be present which often escape detection, as affected patients have no signs or symptoms suggesting an autoimmune disease. However, sterility/infertility in women of childbearing age can be considered, particularly in the presence of autoantibodies, as a sign of a potential autoimmune disease. By detecting and appropriately treating autoimmune diseases/antibodies as latent pathogenetic factors underlying gestational morbidity, a part of sterility/infertility has become extinguishable.

\section{Background}

\section{Antibodies and systemic autoimmune diseases - especially antiphospholipid syndrome - in relation to reproductive failures}

The antiphospholipid syndrome (APS) is a systemic autoimmune disease characterised by arterial and venous thrombosis, adverse outcomes in pregnancy, and raised titres of antiphospholipid antibodies (aPLs). The aPls are heterogenous group of autoantibodies that target phospholipid or phospholipid-binding proteins (3). Primary antiphospholipid syndrome (PAPS) is stated if there is no concurrent autoimmune disease, while the diagnosis of secondary antiphospholipid syndrome (SAPS) is established if it occurs concomitantly with another autoimmune condition such as systemic lupus erythematosus (SLE) (4). An acute variant of the syndrome - catastrophic antiphospholipid syndrome (CAPS) - results in widespread thrombotic microangiopathy and multiple organ failure (5). 
In 1999 published Sapporo preliminary classification criteria for APS were revised in Sydney in 2004 (published in 2006), for establishing the diagnosis of APS, concomitant presence of a clinical and a laboratory criterion is required $(5,6,7,8)$ (Table I).

The manifestations of this syndrome can include: venous thrombosis - deep vein thrombosis, pulmonary embolism, Budd-Chiari syndrome, renal vein thrombosis and ocular vein thrombosis; arterial thrombosis - stroke, transient ischemic attack, amaurosis, myocardial infarction and limb ischemia (9). However, livedo reticularis, cutaneous ulcers, Dego's disease, superficial thrombophlebitis, Raynaud syndrome, cardiac valve abnormality, cardiomyopathy, epilepsy, migraine, chorea, transverse myelopathy, cognitive impairment, aPL-associated nephropathy, pulmonary hypertension, Addison's disease, hypopituitarism, avascular necrosis of bone, thrombocytopenia can occur as the clinical symptom of APS (10). Apart from these symptoms some less frequent aPLs neither included into the diagnostic criteria such as immunoglobulin A anti-cardiolipin antibody (IgA aCL), anti-beta-2 glycoprotein 1 antibody (aß2GPI), anti-Annexin V antibody (aANX), anti-phosphatidyl serine antibody (aPS), anti-phosphatidyl ethanolamine antibody (aPE), and anti-prothrombin antibody (aPT) (6).

The aPLs - arise from immunoglobulin M (IgM) antibodies at low titres - are found in 1-5 \% of healthy subjects without thrombosis or adverse pregnancy outcome. Their prevalence increases with age and may be influenced by infections, malignancies, and the use of several drugs. For this reason, the definitive diagnosis of APS requires the presence clinical criteria with positive laboratory results at least two separate occasions 12 weeks apart because only persistent aPLs are clinically relevant (5).

In APS - as in a hypercoagulable state - the aPLs cause platelet activation, impairment of the endothelial system, facilitation of blood coagulation (3). Namely, after having bound to phospholipids and phospholipid-binding proteins, aPLs hinder the function of those in the regulation of haemostasis. Thus they can inhibit the functions of beta-2 glycoprotein I, protein $\mathrm{C}$, protein S, prothrombin, and Annexin V. In addition, aPLs also activate endothelial cells leading to an increased production of arachidonic acid metabolites, adhesion molecules and cytokines, resulting in an enhanced disposition for thromboembolism also by this way (11).

In pregnancy, placenta is the target organ of APS, where ischemic infarctions develop due to intimal proliferation, fibrinoid necrosis and intraluminal thrombosis of the spiral arteries $(12,13,14)$. 
Table I: Classification criteria for antiphospholipid syndrome (Sydney 2006)

Antiphospholipid syndrome is present if at least one of the clinical and one of the laboratory criteria that follow are met

\section{Clinical criteria}

\section{Vascular thrombosis}

One or more episodes of arterial, venous, or small vessel thrombosis in any tissue or organ. Thrombosis must be confirmed by objective validated criteria (unequivocal findings on appropriate imaging studies or histopathology). For histopathological confirmation, thrombosis should be present without evidence of inflammation in the vessel wall.

\section{Pregnancy morbidity}

a. One or more unexplained deaths of a morphologically normal fetus at or beyond the $10^{\text {th }}$ week of gestation, with normal fetal morphology documented by ultrasound or by direct examination of the fetus, or

b. One or more premature births of a morphologically normal neonate before the $34^{\text {th }}$ week of gestation because of eclampsia or severe preeclampsia defined according to standard definitions, or recognized features of placental insufficiency, or

c. Three or more unexplained consecutive spontaneous abortions before the $10^{\text {th }}$ week of gestation, with maternal anatomic or hormonal abnormalities and paternal and maternal chromosomal causes excluded.

\section{Laboratory criteria}

1. Lupus anticoagulant (LA) present in plasma, on two or more occasions at least 12 weeks apart, detected according to the guidelines of the Internal Society on Thrombosis and Haemostasis.

2. Anticardiolipin (aCL) antibody of $\operatorname{IgG}$ and/or IgM isotype in serum or plasma, present in medium or high titer ( $>40 \mathrm{GPL}$ or MPL, or $>$ the $99^{\text {th }}$ percentile), on two or more occasions, at least 12 weeks apart, measured by a standardized ELISA.

3. Anti-beta-2 glycoprotein I (aß2GPI) antibody of IgG and/or IgM isotype in serum or plasma (in titer $>$ the $99^{\text {th }}$ percentile), on two or more occasions, at least 12 weeks apart, measured by a standardized ELISA, according to recommended procedures. 
There are several known hypotheses relating to the pathogenic role of aPLs which elicit disordered placental function. On one hand, disequilibrium of arachidonic acid metabolites develops in the placenta: in the endothelial cells aPLs impede the production of prostacyclins which play an important role by helping vasodilatation and inhibiting platelet aggregation; and thus the result is accumulation of the procoagulant thromboxane A2. On the other hand, by binding to placental anticoagulant proteins (PAP), aPLs inhibit the function of natural anticoagulants $(15,16)$ (Figure 1).

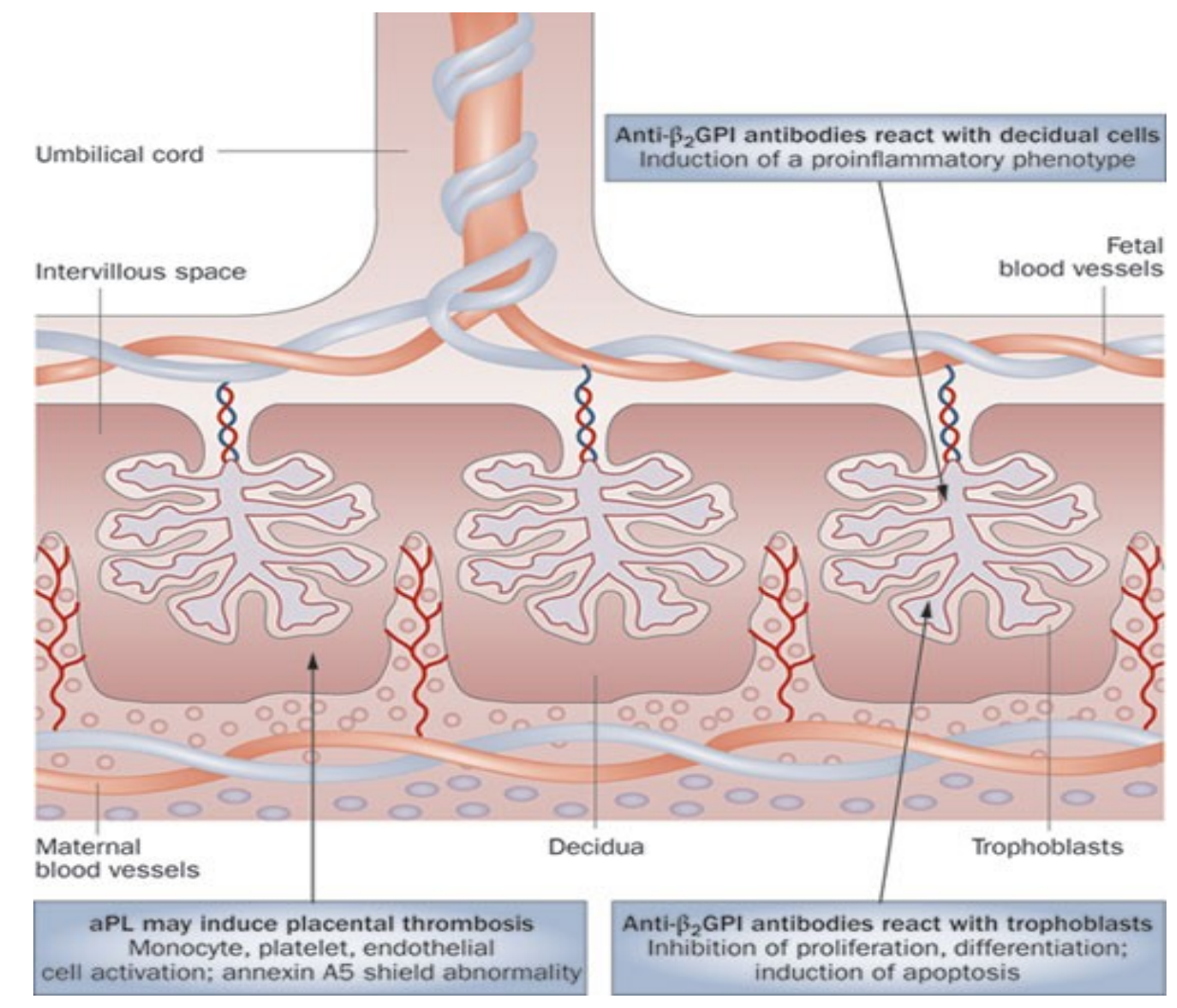

Figure 1: Several pathogenic mechanisms mediate aPL-associated fetal loss. Placental thrombosis might be induced by aPLs binding to monocytes, endothelial cells, platelets and plasma components of the coagulation cascade. Non-thrombotic mechanisms are thought to involve direct effects of $\mathrm{a} \beta_{2}$ GPI autoantibodies on the placenta: binding of aPL to $\beta_{2} \mathrm{GPI}$ expressed on trophoblast membranes might trigger membrane perturbation, resulting in modulation of several cell biological functions, decrease of trophoblast proliferation and growth, and eventually defective placentation; preliminary evidence suggests that aPLs might also affect the maternal side by reacting with endometrial cells in the decidua, inducing a proinflammatory phenotype that might interfere with physiological implantation. Abbreviations: aPLs: anti-phospholipid 
autoantibodies; $\beta_{2}$ GPI: $\beta_{2}$ glycoprotein I. P. L. Meroni, M. O. Borghi, E. Raschi, F. Tedesco: Pathogenesis of antiphospholipid syndrome: understanding the antibodies. Nature Reviews Rheumatology, 7., 330-339., 2011.

Immunoglobulin $\mathrm{G}(\mathrm{IgG})$ and immunoglobulin $\mathrm{A}(\mathrm{IgA})$ isotype antibodies against $\beta_{2}$ glycoprotein (which is produced in large amounts also by trophoblast cells from Week 7 of gestation) are considered much more specific to APS than aCL. Namely, aCL antibodies, when bound to phospholipids, overlay $\beta_{2}$ glycoproteins so that formation of aß2GPI becomes difficult. Nevertheless, serum levels of aß2GP1 may be significantly elevated in aCL-negative patients with APS. A close correlation has been demonstrated between the presence of a 32 GPI-IgM and the occurrence of abortions during an early phase of pregnancy $(17,18)$. Annexin $\mathrm{V}$ is one of the most significant placental anticoagulant proteins that can be detected in a reduced quantity from placentas of mothers with APS $(15,16)$. In addition, an important role is attributed to Annexin V in the course of undisturbed placentation as well. Therefore, antibodies produced against it lead to foetal loss partly by enhancing disposition for thrombosis in the placenta, partly by inducing apoptosis of trophoblast cells and reduction of their gonadotropin secretion. The risk of abortions during the late phase of pregnancy is particularly high in the presence of IgG isotype aANX antibodies $(17,18)$. In addition, in the first trimester of pregnancy, aPLs may induce disorders of placentation and embryonal implantation by directly inhibiting hormone production and invasion of trophoblasts (15). Especially antibodies produced against phosphatidyl serine mostly cause disorders of embryonic implantation as these antibodies induce apoptosis of trophoblast cells, inhibit cell proliferation and syncitium formation, decrease human chorionic gonadotropin production and result defective invasiveness (15) (Figure 2). The aPLs also induce abnormalities at the maternal side of the placenta which could be found on endometrial biopsies. Before conception impaired endometrial differentiation and lower expression of complement regulatory proteins $(\mathrm{DAF} / \mathrm{CD} 55)$ by the aPLs may compromise implantation and predispose to complement-mediated pregnancy failure. Meroni et al reported that placental tissues display reduced heparin-binding epidermal growth factor (HB-EGF) expression in APS and aPLs bind trophoblast monolayers and significantly reduce HB-EGF in vitro synthesis and secretion. HB-EGF plays an essential role in blastocyst implantation and is downregulated in preeclampsia and hypertensive pregnancy disorders associated with defective extravillous trophoblast invasion, 
furthermore heparin can inhibit trophoblast aPL-binding and restore HB-EGF expression in a dose-dependent manner (19) (Figure 2). On the whole, pregnancy complications in APS may be mediated by several different pathogenic events such as thrombotic mechanisms and defective placentation caused by aPLs. But many questions concerning APS in pregnancy are left unanswered.

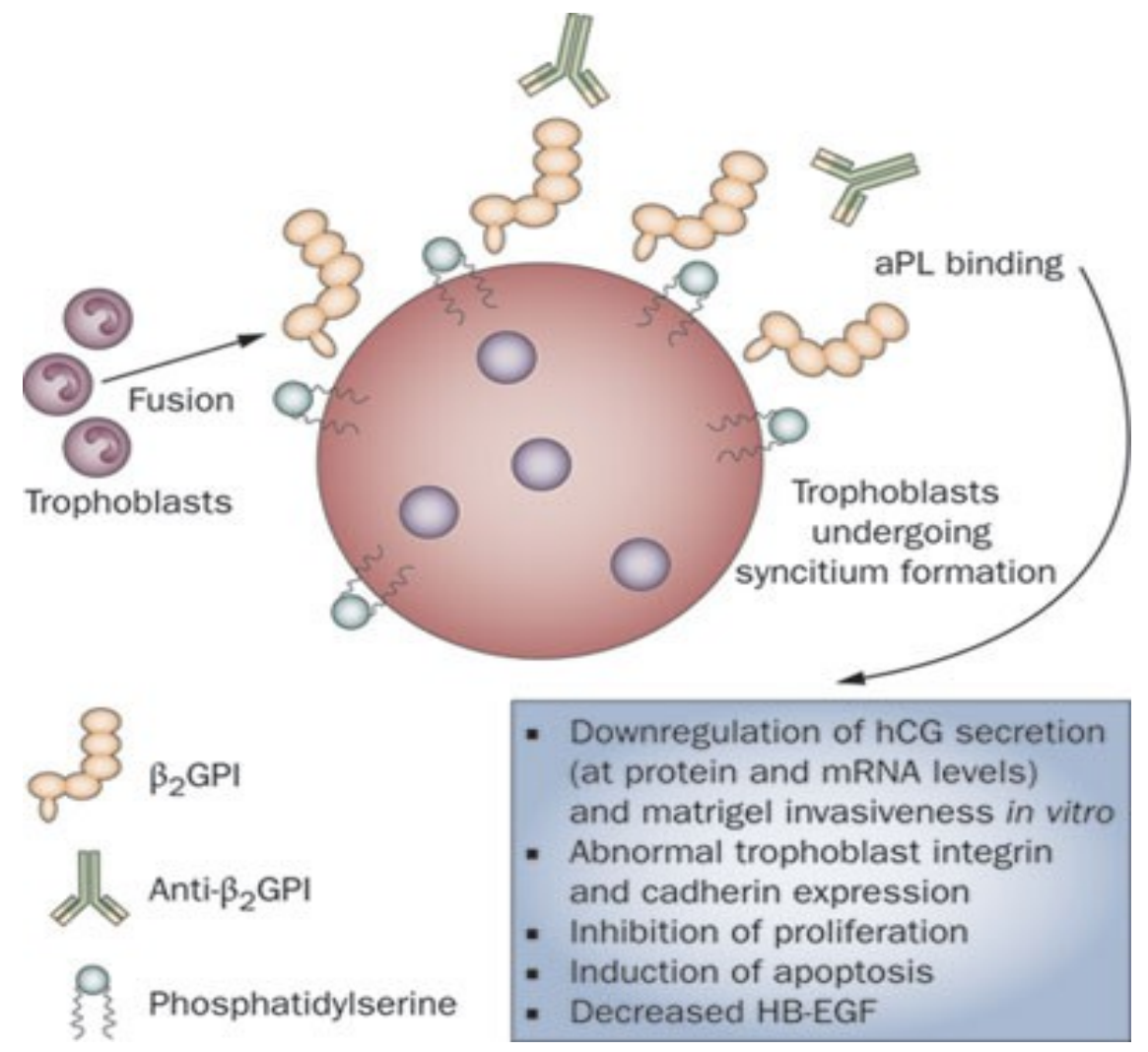

Figure 2: aPLs might affect trophoblast cells directly. Mononuclear trophoblasts fuse during syncitium formation, and phosphatidylserine molecules flip to the outer layer of the cell membrane. $\beta_{2}$ GPI can be expressed on the cell membrane of syncitiumtrophoblast, perhaps due to binding to phosphatidylserine, and be recognized by circulating $a \beta_{2}$ GPI antibodies. Once bound, the antibodies induce cell membrane perturbation resulting in modulation of several biological functions. Abbreviations: aPLs: anti-phospholipid autoantibodies; $\beta_{2} \mathrm{GPI}$ : $\beta_{2}$ glycoprotein I; hCG: human chorionic gonadotrophin; HB-EGF: heparin-binding EGF-like growth factor. P.L. Meroni, M.O. Borghi, E. Raschi, F. Tedesco: Pathogenesis of antiphospholipid syndrome: understanding the antibodies. Nature Reviews Rheumatology, 7., 330-339., 2011 . 
Of systemic autoimmune diseases, only the diagnostic criteria of APS include gestational morbidity (Table I). However, only spontaneous abortion and premature birth have been included into the clinical criteria, while manifestations of the condition which can be brought into connection with pregnancy are much more diversified. APS can cause placental abruption, preeclampsia (18\%), pregnancy-induced hypertension, foetal death $(7 \%)$, fetal growth restriction (31\%), premature labour (43\%), stillbirth, and eventually also sterility $(4,12,13,20,21)$. In various clinical studies, APS-related abortions occurred with an incidence of 15 to $90 \%$ (15). APS was the underlying cause in $36 \%$ and $16 \%$ of abortions/foetal deaths occurring in early and late pregnancy respectively. When aPLs can be detected in a woman with a negative history of thromboembolism, the risk of an aborted pregnancy is $16 \%$ (12). Additionally aPLs are reported to be present in $15 \%$ of women with recurrent first trimester loss (21). Furthermore, the incidence of aCL autoantibodies was found to be $17.3 \%$ when examined in infertile women only, in contrast to $4 \%$ in a control group with negative gestational history (12).

In order to confirm the latter, detection of further autoantibodies in sterile/infertile women should be sought for. Antinuclear antibody (ANA) occurs rather frequently, in approximately 8 to $50 \%$, it can be observed mostly in case of infertility, and usually it can be found together with other autoantibodies, more often with aCL and less frequently with anti-double-stranded DNA antibody (anti-dsDNA). Data of the literature show that anti-dsDNA may be present in $2 \%$ of women with habitual abortions (14). Of antibodies against extractable nuclear antigens (ENA-Profile), 3component antibody to non-histone proteins (anti-SS-A) (especially in association with elevated serum immunoglobulin E levels) as well as antibodies against ribonucleoproteins (anti-RNP), when present in high titres, may lead to abortion (14, 22). As APS, that belongs to acquired thrombophilias, is usually demonstrated in patients with repeated events of thromboembolism which cannot be explained by other causes, these patients require life-long anticoagulation $(2,3)$. As for the therapy of APS demonstrated to underlie pregnancy morbidity without thromboembolism, however, no consensus has been attained. It matters a lot treatment of pregnants who haven't got any antibodies and/or their clinical picture is not fulfil the criteria of APS (23).

When administered in low doses (75 to $100 \mathrm{mg} /$ day) acetylsalicyclic acid (ASA) inhibits thromboxane A2 production and thus it leads to accumulation of vasodilator prostacyclins that is important in keeping the spiral placental arteries open (24). In a 
placebo-controlled study, however, no significant difference was found between patients with APS who received either ASA in a dose of $75 \mathrm{mg} /$ day or placebo, regarding live birth as well as maternal and foetal complications which occurred during pregnancy/labour (23). Opinions are also varying on the issue whether ASA alone or ASA plus heparin therapy is more effective $(25,26)$. Namely, Farquharson et al found that ASA (75 mg/day) plus low molecular weight heparin (LMWH) (5000 IU/day) was not more effective than ASA (75 mg/day) monotherapy (25). In contrast, Kutteh after having studied the outcomes of pregnancies in women with APS demonstrated that ASA (81 mg/day) plus unfractionated heparin (UFH) (10000 - $20000 \mathrm{IU} /$ day) therapy was more effective in comparison to ASA ( $81 \mathrm{mg} /$ day) monotherapy (27). Also in relation to in vitro fertilization (IVF) in women carrying aPLs and treated with ASA and/or heparin, a higher number of conceptions occurred than in aPL-seronegative women who received no therapy (24).

The exact mechanism of how heparin reduces pregnancy loss is still not fully understood. Apart from its anti-coagulant effect, which prevents placental infarctions, heparin was also shown to bind to aPLs and render them biologically inactive. Consequently, by inhibiting aPLs heparin interferes the aPLs-induced complement system activation - especially those involving C3 and C5 - is an important mechanism for aPLs-induced fetal loss $(28,29)$ (Figure 3).

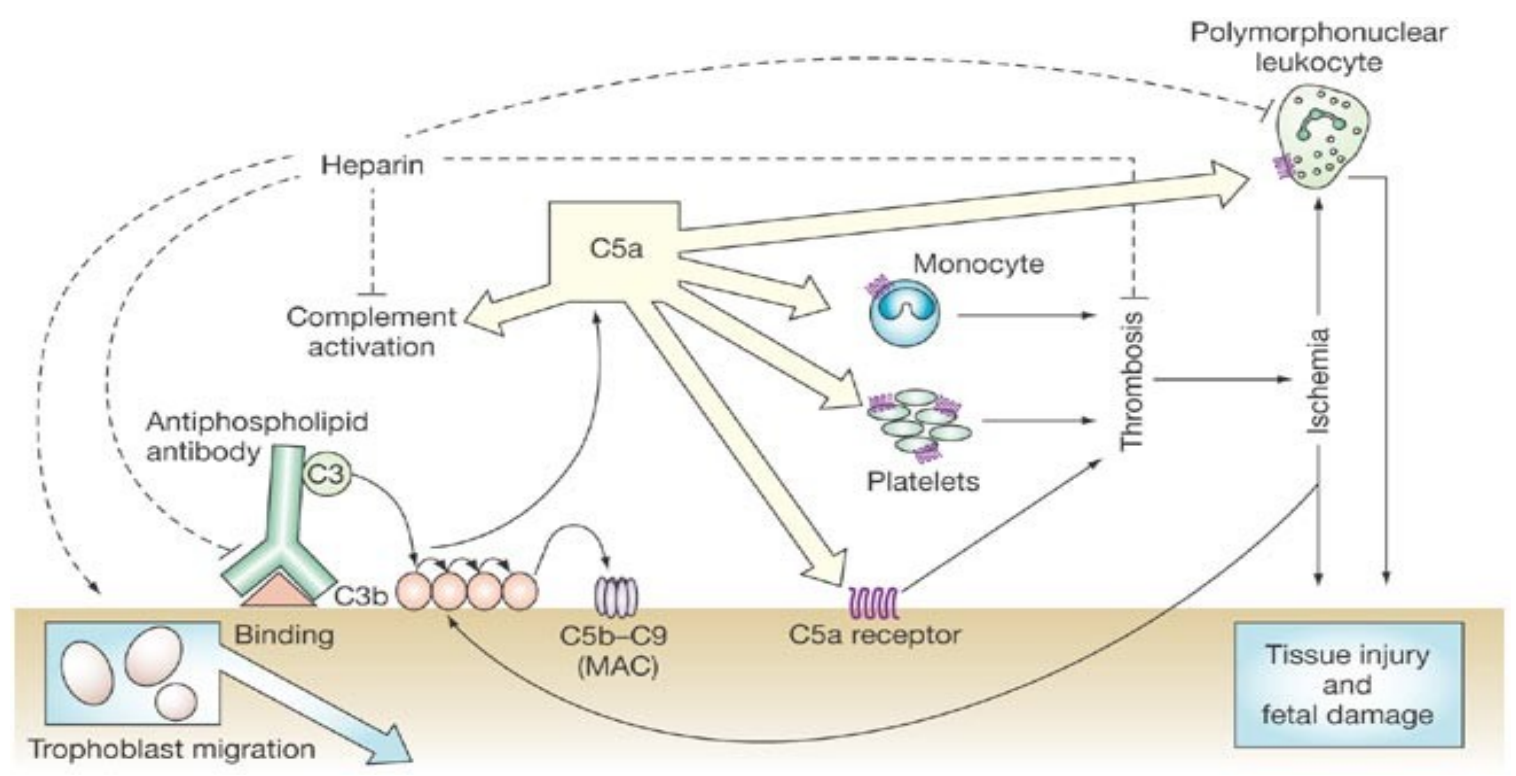

Figure 3: Heparin interferes function of polymorphonuclear leukocyte, aPLs binding, complement system activation and clot formation, furthermore it promotes trophoblast 
migration too. J.E. Salmon, G. Girardi, M D. Lockshin: The antiphospholipid syndrome as a disorder initiated by inflammation: implications for the therapy of pregnant patients. Nat Clin Pract Rheumatol, 3., 140-147., 2007.

Besides protection against pregnancy loss, heparin was also demonstrated to reduce obstetrical complications such as preeclampsia and low birth weight $(28,30)$. The combination of either LMWH or UFH with aspirin doesn't result significant difference in fetal outcomes and maternal complications in either form of heparin. However, LMWH may be a much more advantageous choice in contrast with UFH as it has got lower risks of haemorrhage, thrombocytopenia, bone loss and easier administration (28).

To sum up, the most of all accepted recommendation for the treatment of APS in pregnancy is:

1. APS with recurrent early miscarriage and without previous thrombosis: low-dose ASA alone or together either UFH (5000 - 7500 IU every 12 h) or LMWH (prophylactic doses).

2. APS with fetal death (more than $10^{\text {th }}$ weeks of gestation) or previous early delivery (before $34^{\text {th }}$ weeks of gestation) due to severe preeclampsia or placental insufficiency and without previous thrombosis: low-dose ASA plus UFH (7500 - 10000 IU every 12 $\mathrm{h}$ in the first trimester, $10000 \mathrm{IU}$ every $12 \mathrm{~h}$ in the second and third trimester) or LMWH (prophylactic doses).

3. APS with previous thrombosis: low-dose ASA plus UFH (therapeutic doses) or LMWH (therapeutic doses) (31).

Vitamin $\mathrm{K}$ antagonists are teratogenic, for this reason they should be avoided in the first trimester of gestation. Nevertheless, warfarin after $12^{\text {th }}$ weeks of gestation may be given only exceptional circumstances (31).

Corticosteroids are not suitable for reducing serum levels of aPLs in patients with APS; their use is considered reasonable, adjoining to anticoagulation, mainly in patients with SAPS $(13,14)$. Hasegawa et al found the combination ASA (81 mg/day) plus prednisolone $(10 \mathrm{mg} /$ day) equally effective in relation to IVF both in ANA and aPL copositive and in ANA-positive and aPL-negative women (32). Intravenous immunoglobulin (IVIG) has also proven to be not more effective than ASA plus LMWH therapy in patients with abortions due to aPLs $(33,34)$. Administration of IVIG is recommended as an adjunct to anticoagulation in patients with severe data of history 
(e.g. cerebrovascular thromboembolism, eclampsia) or with repeated abortions occurring during the use of ASA and/or heparin $(13,33,34)$.

\section{Autoimmune thyroiditis and thyroid dysfunction in relation to reproductive} failures

Currently, in the assessment of women with reproductive failure, a search for the diagnosis of both overt and latent hypothyroidism receives more and more emphasis as these pathological states influence not only the course of pregnancy and the fetus, but the development of the newborn as well (35).

Hypothyroidism is characterized by anovulatory cycles and therefore even fertilization occurs more rarely in women with this disease; if it does happen, however, complications related to pregnancy are to be reckoned with more frequently (35.). A Finnish study showed significantly higher incidence of hypothyroidism among women with infertility and ovulation disorders in comparison to the control group $(35,36)$. In addition, women with autoimmune thyroiditis who are carriers of antithyroid peroxidase (anti-TPO) antibodies have a higher risk of becoming infertile even in a euthyroid state $(37,38)$, and it is also true vice versa as anti-TPO is found in infertile women more frequently (39). Also, a small but already significant elevation of serum TSH level has been observed in anti-TPO positive infertile women as compared to a healthy control group $(37,38)$.

A survey of Klein et al showed that overt or latent hypothyroidism could be diagnosed in $0.3 \%$ and $2.5 \%$ of pregnant women respectively; and these may lead to various complications of pregnancy $(35,40)$. Hypertension of pregnancy was found with an incidence of $11.6 \%$ (3.8\% in a healthy population) (41), including $11 \%$ in latent hypothyroidism; while its incidence was $23 \%$ in those with an overt hypothyroidism (42). In patients with subclinical hypothyroidism, placental abruption occurs three times more often, while premature labor (prior to the $32^{\text {nd }}$ week of gestation) and respiratory distress syndrome of the newborn, both occur twice more frequently as compared to healthy pregnant women (43). The incidence of spontaneous abortion may even reach $45 \%$ in pregnant women with untreated hypothyroidism (35). A close connection is supposed to exist between anti-TPO positivity with no thyroid dysfunction and spontaneous abortions, as several studies found a two- to fourfold increase in the occurrence of spontaneous abortion in anti-TPO positive euthyroid pregnant women as 
compared to the anti-TPO negative ones $(44,45)$. Two underlying causes are presumed: on the one hand anti-TPO antibodies occur commonly in association with other autoantibodies (antiphospholipid antibodies, ANA, anti-SS-A) which may also contribute to the cessation of pregnancy; on the other hand in the decisive majority of cases of antiTPO positivity there is a slightly elevated level of TSH (by $0.81 \mathrm{mU} / \mathrm{L}$ on the average) what already shows an impaired thyroid function, so that the thyroid gland fails to meet the increased requirements for its hormones during pregnancy (35). Spontaneous abortions occurred in $13.8 \%$ of women with latent hypothyroidism due to autoimmune thyroiditis, and that could be reduced to $3.5 \%$ by thyroid hormone replacement (control group: $2.4 \%$ ). The occurrence of premature labor was found to be $22.4 \%$, what decreased to $7.0 \%$ as a result of the therapy (control group: $8.2 \%)(35,39)$.

Thyroid hypofunction in pregnant women exerts a deleterious effect on the later development of their children, as two studies found a correlation between the latent or mild hypothyroidism observed during the mother's pregnancy and the lower IQ values of their offspring $(38,40,46,47)$. In addition, the children's IQ and their educational performance were similar to those of the control group if the pregnant women had received thyroid hormone substitution $(38,40)$. Also iodine deficiency should not be left out of consideration as, in addition to autoimmune thyroiditis, it may be an underlying cause of hypothyroidism in pregnant women and it may exert an aggravating effect not only on the intrauterine but also on the postnatal development of their children. In areas poor in iodine an increased incidence of attention-deficit hyperactivity disorder (ADHD) has been demonstrated in children of mothers who had hypothyroidism already during the first trimester of their pregnancy; this was caused by an insufficient transplacental supply of maternal thyroid hormone for the fetal brain during the period of gestation so that its development has become impaired $(35,48)$.

Based on the above, the question emerges, whether a screening for (autoimmune) thyroid diseases in pregnant women is required. In order to clarify this issue, a consensus conference was held in 2002, and in their formulated recommendation a screening of all pregnant women was considered unnecessary, however performance of a TSH test was recommended in those women in child-bearing age or with pregnancy, whose personal or family history included thyroid disease, who had symptoms suggesting hypothyroidism, and who had type 1 diabetes mellitus, organ-specific or systemic autoimmune diseases (49). In 2005 the topic was reconsidered and an alternative recommendation was issued according to which $\mathrm{TSH}$ test should be 
performed in all pregnant women (50). However this has been opposed by several authors who call for a first-of-all clarification of the question, which laboratory tests (TSH is sufficient or FT4 is also needed?) and when should be performed in pregnant women $(51,52)$. Based on the most accepted standpoint, TSH test, with an upper limit of $2.5 \mathrm{U} / \mathrm{L}$, should be performed during the first trimester of pregnancy; if hypothyroidism is detected, follow-up TSH monitoring at every 6 to 8 weeks is recommended during a period of hormone replacement (35).

As there is a known relationship between anti-TPO positivity associated with euthyroidism and the occurrence of spontaneous abortions and premature births, the incidences of which can be reduced significantly by levothyroxine therapy, therefore the timing and requirement of anti-TPO tests should also be determined in the future (35, 39).

\section{Celiac disease in relation to reproductive failures}

Celiac disease (CD) is an autoimmune process developing in genetically susceptible individuals exposed to the effects of certain environmental factors. $95 \%$ of patients are HLA-DQ2 positive, in addition they often carry HLA-DQ8 allele and there may be other underlying genetic factors as well. However, genetic susceptibility alone is not enough for manifesting the pathognomonic signs and symptoms of the disease; exposition to the gluten content of wheat, barley or rye is also essential; this recognition is the source of the condition's other name, gluten-sensitive enteropathy. In the sera of patients there are auto-antibodies of which anti-endomysium, anti-gliadin and antitissue-transglutaminase (anti-tTG) antibodies are of particular importance (53) (Figure 4). Tissue transglutaminase enzyme that plays a part in cellular apoptosis, enters the extracellular space upon the cell's injury due to the gliadin component of gluten, and results in the development of neoantigens and peptides with strong negative charge (53). By activating CD4+ $\mathrm{T}$ cells, these antigens induce a Th1 immune response, the effector phase of which implies the destruction of intestinal mucosa in the small bowels by CD8+ T cells, natural killer cells and matrix metalloproteinases of fibroblast origin (53). In addition to the positive immuno-serological findings, histopathological examination of the affected intestinal mucosa and demonstration of villous atrophy are always required for the diagnosis of $\mathrm{CD}$ (Figure 4). 


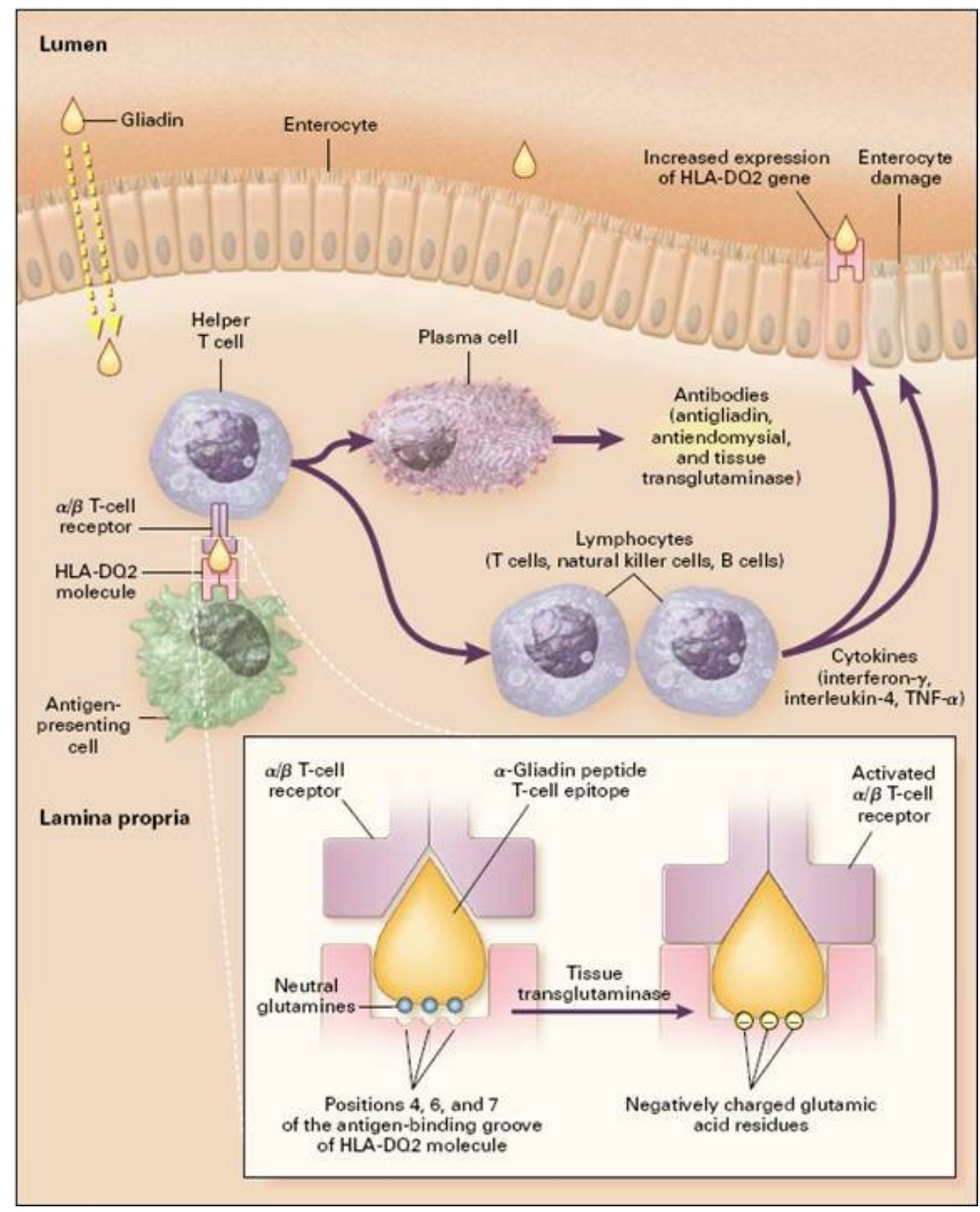

Figure 4: Image depicting the role of MHC molecule, HLA-DQ2 (or 8) contributes to inflammation in the gut via the production of IFN-gamma and TNF-alpha, which when goes unregulated, leads to tissue destruction in the intestines. R.W. DePaolo, V. Abadie, F. Tang, H. Fehlner-Peach, J.A. Hall, W. Wang, E.V. Marietta, D.D. Kasarda, T.A. Waldmann, J.A. Murray, C. Semrad, S.S. Kupfer, Y. Belkaid, S. Guandalini,B. Jabri: Co-adjuvant effects of retinoic acid and IL-15 induce inflammatory immunity to dietary antigens. Nature, 471. (7337), 220-224., 2011.

Gluten sensitivity may produce not only gastrointestinal signs and symptoms, as tissue transglutaminase enzyme is present, among others, in the cells of skin, muscles, nervous system, and liver so that it may be associated with various clinical signs and symptoms (54). Of extraintestinal manifestations, infertility is of special importance because gluten sensitivity may be the underlying cause of delayed menarche, early menopause, secondary amenorrhea, infertility, habitual abortions, fetal retardation, premature birth 
and stillbirth in women, and gonadal dysfunction and abnormalities of sperm in men $(55,56,57,58,59,60)$.

At first in 1888 Gee reported on a reversible atrophy of intestinal mucosa of the small bowels leading to malabsorption in patients showing certain genetic susceptibility (61). The term celiac disease was used first time by the Dutch pediatrician Dicke in the second half of the 1940's; at that time gluten sensitivity was observed exclusively in children (61). Up to now the previous notions about CD underwent significant changes as forms of the disease in adult patients, not associated with gastrointestinal symptoms and affecting other organ systems have come more and more to the forefront. Ferguson compared the total patient population with $\mathrm{CD}$ to an iceberg, the mere small tip of which over the waterline represents the diagnosed cases showing a typical clinical picture, while patients with "silent", "latent" and "potential" celiac disease are located under the waterline (62).

The prevalence of $\mathrm{CD}$ in the general population is about $0.5-1 \%$ with a female predominance (female/male: $2 / 1,3 / 1$ ), however the prevalence may vary in the different geographical areas (61). Gluten sensitivity is often associated with type 1 diabetes mellitus, hypothyroidism, Addison's disease, Turner and Down syndrome (61, 63). In spite of the more and more extended screening programs, study results unequivocally show that in $50-90 \%$ of individuals with $\mathrm{CD}$ the disease will not be diagnosed even nowadays (they form the body of the iceberg), and only the tip of the iceberg continues to come into our field of vision (61). Undiagnosed patients usually have no gastrointestinal symptoms or only very mild complaints; in these cases gluten sensitivity may be indicated by epilepsy developing as a result of calcification in central nervous system; dental abnomalies, endocrinologic conditions (e.g. autoimmune thyroiditis), polyarthritis, depression, or pathologic obstetric-gynecologic states $(54,64)$.

Screening the entire population for CD would be cost-ineffective; however in certain situations, such as in patients with idiopathic infertility, other autoimmune pathologic entities or occurrence of $\mathrm{CD}$ among members of their family, the performance of screening tests has relevance (65).

When screening subfertile and infertile women for $C D$, its prevalence was found to be 2.7-3 \% (54, 66) and 4-8 \% (67) respectively; however Kolho et al $(57,59)$ found no difference between the prevalence in this group of patients and the general population $(2.1 \%$ vs. $2.0 \%)$. Several authors $(56,58,60,63,66)$ reported delayed menarche in women with $\mathrm{CD}$ as compared to healthy controls (Ferguson: $15 \pm 2$ vs. $13.5 \pm 1$ years; 
Sher: $13.6 \pm 1.6$ vs. $12.7 \pm 1.4$ years; Molteni: 13.5 vs. 12.1 years) as well as early menopause (Ferguson: $45 \pm 5.5$ vs. $53 \pm 1.2$ years; Sher: $47.6 \pm 4.4$ vs. $50.1 \pm 3.5$ years; Molteni: 45.5 vs. 49.5 years). The prevalence of secondary amenorrhea was found much more frequent (39\% vs. $9 \%)$ while the number of born children $(1.9 \pm 0.9$ vs. $2.5 \pm$ 1.2) lower than in their healthy contemporaries $(58,60,63)$. The manifestation of pathological gynecologic conditions showed no correlation with the severity of CD or the nutritional status of patients; however cessation of habitual abortions was observed upon normalization of any potential folic acid deficiency $(63,68)$.

Of pathological obstetric conditions, a correlation between habitual abortions and CD was reported at first by Morris et al in the 1970's (59). In women with undiagnosed CD the prevalence of habitual abortions has proven to be considerably higher in several various clinical studies $(58,59,60,66,69)$ as compared to the group of healthy controls (Ogborn: 21 vs. 4 \%; Molteni: 27 vs. 6.9 \%; Sher: 15 vs. 5 \%), however Kolho et al (67) demonstrated no significant difference between the two groups with regard to the prevalence $(1.6 \%)$ of recurring abortions. The importance of the results lies in the fact that in women with already diagnosed CD the number of habitual abortions can be reduced by gluten-free diet (Sher: 15 vs. $7 \%$; Ciacci: 43.3 vs. $7.7 \%$; Ferguson: 17.8 vs. $9 \%)(55,56,60,63)$. The prevalence of stillbirth in women with $\mathrm{CD}$ is about $5.4 \%$ that can be ceased completely by keeping a strict diet (56). As obstetrical complications of undetected or untreated gluten sensitivity, preeclampsia, placental abruption and an increased number of deliveries by cesarean section have also been documented (63). Intrauterine growth retardation (IUGR) and low birth weight $(\leq 2499 \mathrm{~g})$ can be considered as independent risk factors for the future development of certain chronic illnesses such as type 1 and type 2 diabetes mellitus and cardiovascular diseases (61, 71). An extremely close and multifaceted relationship is presumed to exist between the presence of $\mathrm{CD}$ in the parents and the birth weight of their newborns. A Danish study showed that the birth weight of newborns of mothers with untreated $C D$ was significantly lower (-238 g) as compared to those of healthy control mothers. On the other hand, newborns of mothers with CD who kept a gluten-free diet were delivered with birth weight on average higher by $67 \mathrm{~g}$ in comparison to newborns of healthy mothers examined as negative controls $(63,72,73)$. The above is confirmed also by the observation of Ciacci et al who found that IUGR (seen in $29.4 \%$ of untreated mothers) 
can be ceased by gluten-free diet, and the duration of breast feeding can be prolonged by 2.5 months $(55,63,73)$.

In men $\mathrm{CD}$ exerts a known effect on gonadal function, as teratozoospermia and asthenozoospermia may occur in $46 \%$ and $75 \%$ respectively, what has proven to be reversible upon gluten-free diet $(63,66,74,75)$. In addition, the father's disease may also influence the course of pregnancy and the expected outcome of delivery significantly. Namely, the genomes of both parents have a decisive role in relation to normal embryogenesis and satisfactory placental function, and from this aspect paternal genes may conceivably be even more important than maternal ones $(71,75)$. Ludvigsson et al found the birth weight of children whose father had CD (and mother was healthy) significantly lower in comparison to those with a healthy father (3273 g vs. $3596 \mathrm{~g}$ ), while they found no significant difference between mothers with CD and healthy women in relation to birth weight (3447 g vs. $3596 \mathrm{~g}$ ) (19). The risk of developing IUGR is fivefold higher in case of fathers with CD than in the general population (11\% vs. $2.5 \%)(71,76)$.

Summing up, we can state that gluten sensitivity should be taken into consideration in pathological states of pregnancy even in symptom-free patients. Assessment and therapy of anti-tTG positive patients and follow-up of pregnancies in female patients with $\mathrm{CD}$ always require multidisciplinary cooperation; in addition we wish to emphasize that as for the outcome of pregnancy, also male members of the couples should not be left out of consideration.

\section{Anti-sperm antibody in relation to reproductive failures}

Anti-sperm antibodies are produced both in men and in women; these may cause infertility and repeated abortions occurring in early pregnancy, as well as they may result in a failure of inseminations and in vitro fertilizations (IVF) $(77,78,79,80,81$, 82). In men who suffered an injury of the blood-testis barrier (e.g. vasectomy, trauma of the testes, local inflammation due to genital infections) antigens of the spermia become accessible for the immune system in the regional lymph nodes and a production of autoantibodies may start which can lead to an immunological blockade of spermatogenesis/spermiogenesis $(77,83)$. In women the genital mucosa may be injured during coitus or IVF, and through this a sensitization can take place and then anti-sperm alloantibodies may be produced $(77,83)$. 
IgG-type anti-sperm antibodies appear at first in the blood, and only thereafter can be detected in the sperm in men and in the cervical mucus in women; i.e. the reproductive failure is primarily caused not by the locally produced IgA antibodies $(77,85)$. Regarding their effect, they may impair the viability of the spermia, their transport in the uterine tube, their penetration to the cervical mucus, as well as the interaction between ova and spermia, and the development of the embryo.

In a Hungarian study the presence of anti-sperm antibodies detected by ELISA method in the sera of infertile married couples was as follows: 1. women's sera positive to the sperm of their husband: $20.0 \% ; 2$. women's sera positive to the sperm of other men: $33.3 \%$; 3. men's sera positive to their own sperm: $7.3 \%$; 4 . men's sera positive for other men's sperm: $15.9 \%$ (77). When examining the cross-reactions, it occurred that a woman showed no reaction to the sperm of her spouse, but reacted to the sperm of other(s), on the other hand a few spermia produced positive reactions to several women's sera as well. All these may raise the possibility that anti-sperm antibodies are produced basically not against the spermia of the own partner, but to other agents with very similar antigenic properties (e.g. bacteria), and their titers increase to a level causing a reproductive failure only due to the frequent exposure to the spermia (77). In addition, anti-sperm antibodies can be detected in patients with SLE, in women with endometriosis, as well as in association with other, mostly anti-dsDNA, anti-TPO, and antiphospholipid auto-antibodies $(78,82,85,86)$. This can be explained by a polyclonal B-cell activation characteristic to autoimmune diseases during which antibodies showing various frequent cross-reactions are produced $(78,87)$.

If a woman is positive for anti-sperm antibodies, transient use of condom by her partner is to be considered, what protects the patient from further antigenic stimuli for a while. This method has a disadvantage that no treatment duration can be determined previously as the disappearance of the antibody shows an individual variability (it often may require even months) $(77,84)$. In addition, both in men and in women, immunosuppressive (corticosteroid) therapy, plasmapheresis, heterologous insemination, or IVF with homologous, repeatedly washed sperm may be considered $(84,88,89,90,91)$. 
AIMS OF THE INVESTIGATION

The aim of our study was to examine the antibodies and autoimmune diseases in relation to reproductive failures.

1. The first aim was to establish the incidence of aPLs which are included into the APS diagnostic criteria (Sydney, 2004.) such as aCL and aß2GPI among the femal patients with reproductive failures.

2. The second aim was to detect some less frequent aPLs neither included into the diagnostic criteria such as aANX, aPS, and aPT by our femal patients.

3. The third aim of our study was to diagnose APS among patients with aPLs when clinical criteria were also taken into consideration and to apply anti-coagulant treatment among them.

4. The fourth aim was to examine femal patients for the systemic autoimmune diseases apart from APS.

5. The fifth aim of our study was to establish the diagnoses of organ-specific autoimmune diseases such as autoimmune thyroiditis and celiac disease and to use their adequate treatment among patients with reproductive failures.

6. The sixth aim was to detect a-sperm antibody in femal patients and to investigate its role in reproductive failures. 


\section{PATIENTS AND METHODS}

\section{Patients}

On the Department of Internal Medicine of Zala County Hospital during 88 months (between September 2004 and December 2011) 500 female patients (mean age: $31.4 \pm 4$ years) were enrolled to our study, including 167 and 333 patients (33\% and 67\%) with sterility and infertility respectively. Any other causes underlying the sterility/infertility could be excluded or have already been eliminated previously in all of them. In addition to history taking and physical examination, our patients underwent the following tests: assay of antinuclear antibody (ANA) by immunofluorescent (IF) method, as well as enzyme-linked immunosorbent assays (ELISA) of anti-double-stranded DNA antibody (anti-dsDNA) (cut off: 25 - $120 \mathrm{U} / \mathrm{mL}$ ), anticardiolipin antibody (aCL) (cut off: 10 - 100 $\mathrm{MPL} / \mathrm{mL}$ and 10 - $104 \mathrm{GPL} / \mathrm{mL}$ ), antibodies against extractable nuclear antigens (ENAProfile) $(>1.2 \mathrm{U} / \mathrm{mL})$ such as anti-histidyl-tRNA synthetase antibody (anti-Jo-1), antiribonucleoprotein antibody (anti-RNP), antibody to Sm-proteins (anti-Sm), antibody to 3-component non-histone proteins (anti-SS-A), antibody to phosphoprotein of RNApolimerase III cofactor (anti-SS-B), anti-thyroid peroxidase antibody (anti-TPO) (cut off: 0 - $30 \mathrm{U} / \mathrm{mL}$ ), anti-phosphatidyl serine antibody (aPS) (> $15 \mathrm{U} / \mathrm{mL}$ ), antiprothrombin antibody (aPT) $(>10 \mathrm{U} / \mathrm{mL})$, anti-beta-2 glycoprotein 1 antibody (aß2GPI) $(>10 \mathrm{U} / \mathrm{mL})$, anti-Annexin $\mathrm{V}$ antibody $(\mathrm{aANX})(>5 \mathrm{U} / \mathrm{mL})$, anti-tissuetransglutaminase antibody (anti-tTG) (cut-off: 0-7 U/mL), and anti-sperm antibody (asperm). We also examined 500 male patients (they are partners of our female patients) (mean age: $38.5 \pm 3$ years) for $\mathrm{CD}$, who underwent the tests of anti-tTG (cut-off: 0-7 $\mathrm{U} / \mathrm{ml}$ ) by ELISA. Furthermore, our anti-tTG positive female and male patients underwent deep duodenal biopsy for histological examination in order to confirm the diagnosis of $\mathrm{CD}$ and we carried laboratory tests out by them too, such as hemoglobin (Hgb) (123-153 g/L), hematocrit (Htc) (0.36-0.46 L/L), serum iron (Fe) (8.7-27.0 $\mu \mathrm{mol} / \mathrm{L})$, serum ferritin $(15-150 \mathrm{ng} / \mathrm{mL})$, serum vitamin B12 $(197-866 \mathrm{pg} / \mathrm{mL})$, serum folic acid (3.1-17.5 $\mathrm{ng} / \mathrm{mL})$, serum total protein (65-80 g/l), serum albumin (33-50 g/L), serum immunoglobulin $\mathrm{G}(\mathrm{IgG})$ (7-16 g/L), se immunoglobulin A (IgA) (0.7-4.0 g/L), se immunoglobulin M (IgM) (0.4-2.3 g/L). Finally, our anti-TPO positive females have been studied for serum thyroid-stimulating hormone (TSH) (0.4-3.2 mU/L), serum free tri-jodide-thyronine (FT3) (2.23-6.50 pmol/L) and free thyroxin (FT4) (9.14-23.81 $\mathrm{pmol} / \mathrm{L})$. 


\section{Methods}

Enzyme-linked immunosorbent assays (ELISA):

Anti-dsDNA was measured by ELISA technique. The surface of a polystyrene microtitration plate was sensitized for DNA overnight. On the next day, following three washings with PBS $+0.05 \%$ Tween, samples were allotted to the wells of the plate doubled in 40x dilution. After 1-hour-long incubation and triple washings, anti-humane IgG/HRP (DAKO AS, Denmark) was pipetted into the wells in $6.000 \mathrm{x}$ dilution. Following a further 1-hour-long incubation and washing, o-phenylenediamine- $\mathrm{H}_{2} \mathrm{O}_{2}$ substrate was applied, and then the color reaction was set by allotting $4 \mathrm{~N}$ sulfuric acid. Results were measured at $492 \mathrm{~nm}$ with Labsystems MS Multiskan ELISA photometer and given in $\mu \mathrm{g} / \mathrm{mL}$ based on a calibration curve for IgG.

Auto-antibodies against ENA and ENA subtypes (SS-A, SS-B, Sm, RNP, Jo-1) as well as antibodies against TPO, tTG, sperm, and aPLs (aCL, aß2GPI, aPS, aPT, aANX) were detected by a commercially available ELISA test (AUTOSTAT II ENA-Screen, antiSS-A, anti-SS-B, anti-Sm, anti-RNP, anti-Jo-1, anti-TPO, anti-tTG, a-sperm, aCL, aß2GPI, aPS, aPT, aANX; Cogent-Hycor, Peniciuk, UK), in accordance with the instructions of the manufacturer.

\section{Immunofluorescent method (IF):}

ANA was detected on HEp-2 cell substrate (Human Epithelioma Type 2 Cells - CCL 23 - American TypeCulture Collection) with a standard indirect immunofluorescent technique. By using a laboratory-cultured cell line, cell preparations were made and fixed in acetone. Patient sera were applied in 40x dilution, and the bound autoantibodies were detected with anti-humane IgG/FITC (The Binding Site, UK). Preparations were evaluated with a Leica Diaplan fluorescent microscope, at 500x magnification. Patterns of IF were created due to binding of ANA to various components of the cell nucleus.

Routine blood tests, TSH, FT3, FT4 and serum immunoglobulins were measured as a part of routine diagnostics, by using of Sysmex XP-1800I, Vacuette SRS 100/II, Modular MODU P8000 and Modular E170 systhems. 


\section{ANTIPHOSPHOLIPID ANTIBODIES AND ANTIPHOSPHOLIPID SYNDROME IN RELATION TO REPRODUCTIVE FAILURES}

\section{Aims}

The aim was to establish the prevalence of aPLs which are included into the APS diagnostic criteria (Sydney, 2004.) such as aCL, aß2GPI, and detect some less frequent aPLs neither included into the diagnostic criteria such as aANX, aPS, and aPT, as well as to diagnose APS.

\section{Results}

Twofold positive aCL was demonstrated in 27/500 patients (5.0 \%) (st/if: 4/23). When clinical criteria were also taken into consideration, 3/27 PAPS could be diagnosed (Table II, V). In 4/27 cases the APS was associated with the presence of another antibodies, such as ANA, anti-dsDNA, anti-SS-A, anti-TPO, a-sperm, however these women didn't suffered from another autoimmune disease, accordingly SAPS couldn't be confirmed, but they were observed towards SAPS (Table II, V) (Figure 5). In further 20/27 cases the clinical picture did not fulfil the criteria of APS as 15 infertile patients were examined already after the first or second abortion prior to Week (W) 10 of gestation, and further 5 patients were sterile (what is not even included in the system of criteria for APS) (Table II).

\begin{tabular}{|c|c|c|c|c|}
\hline $\begin{array}{l}\text { Number } \\
\text { of } \\
\text { patient }\end{array}$ & $\begin{array}{c}\text { Associated antibodies } \\
\text { (ANA, anti-dsDNA, a-sperm, } \\
\text { anti-SS-A, anti-TPO) }\end{array}$ & $\begin{array}{l}\text { aPL antibodies } \\
\text { (aß2GPI, aPS, } \\
\text { aANX, aPT) }\end{array}$ & $\begin{array}{c}\text { Clinical criteria of } \\
\text { APS }\end{array}$ & $\begin{array}{c}\text { Diagnosis of } \\
\text { APS }\end{array}$ \\
\hline $1 / 27$ & - & - & + & PAPS \\
\hline $3 / 27$ & + & - & + & SAPS \\
\hline $2 / 27$ & - & + & + & PAPS \\
\hline 1/27 & + & + & + & SAPS \\
\hline $8 / 27$ & - & - & - & \\
\hline $4 / 27$ & + & - & - & \\
\hline $4 / 27$ & - & + & - & \\
\hline $4 / 27$ & + & + & - & \\
\hline
\end{tabular}

Table II: Female patients showing twofold anti-cardiolipin positivity 
In addition to the twofold positive aCL, less frequent antiphospholipid antibodies (aPLs) including aß2GP1, aPS or both were present in 2/27, 3/27 and 2/27 patients, as well as aANX in $2 / 27$, aANX with together aPS in $1 / 27$ and aPS along with aPT in $1 / 27$ patients respectively (Figure 5).

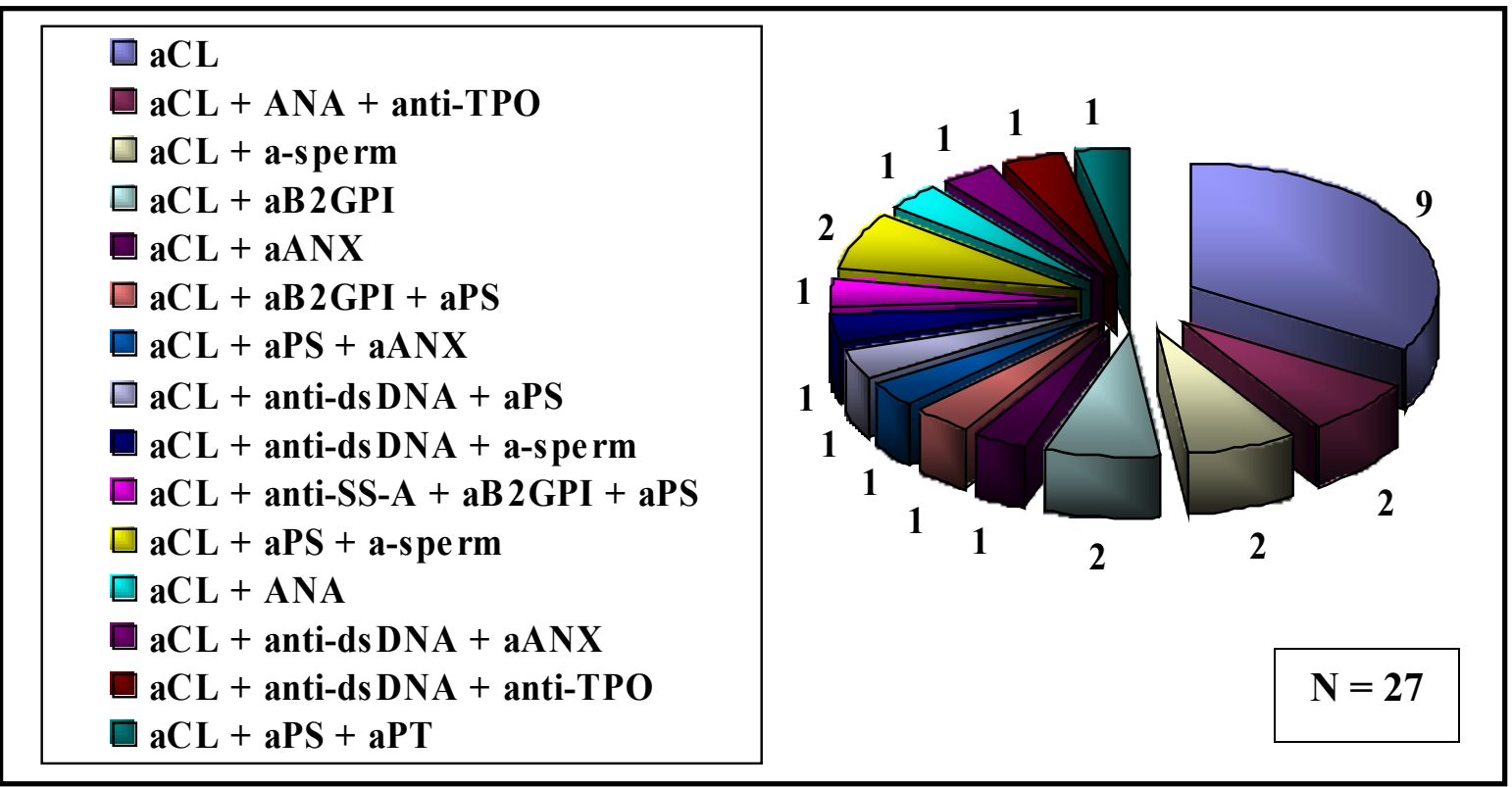

Figure 5: Female patients showing twofold aCL positivity, associated antibodies and aPLs (N: number of patients)

The aCL could be detected on a single occasion in 34/500 women (6.8 \%) (st/if: 17/17), including 2/34 patients where PAPS and 1/34 patients where SAPS was suggested on the base of the clinical picture (Table III, V).

\begin{tabular}{|c|c|c|c|c|}
\hline $\begin{array}{c}\text { Number } \\
\text { of } \\
\text { patient }\end{array}$ & $\begin{array}{c}\text { Associated antibodies } \\
\text { (ANA, anti-dsDNA, a-sperm, } \\
\text { anti-SS-A, anti-TPO, anti-tTG) }\end{array}$ & $\begin{array}{c}\text { aPL antibodies } \\
\text { (aß2GPI, aPS, } \\
\text { aANX, aPT) }\end{array}$ & $\begin{array}{c}\text { Clinical criteria of } \\
\text { APS }\end{array}$ & $\begin{array}{c}\text { Diagnosis of } \\
\text { APS }\end{array}$ \\
\hline $\mathbf{2 / 3 4}$ & - & - & + & PAPS \\
\hline $\mathbf{1 / 3 4}$ & + & + & + & SAPS \\
\hline $\mathbf{9 / 3 4}$ & - & - & - & \\
\hline $\mathbf{5 / 3 4}$ & + & - & - & \\
\hline $\mathbf{6 / 3 4}$ & - & + & - & \\
\hline $\mathbf{1 1 / 3 4}$ & + & + & - & - \\
\hline
\end{tabular}

Table III: Female patients showing one-time anti-cardiolipin positivity

Among one-time aCL-positive patients aß2GPI, aPS, aPT and aANX could be detected in $1 / 34,9 / 34,2 / 34$ and 1/34 patients, as well as aß2GPI with aANX and aß2GPI with aPS and aPS with aANX could be established in 2/34, 1/34 and 1/34 patients (Figure 6). 

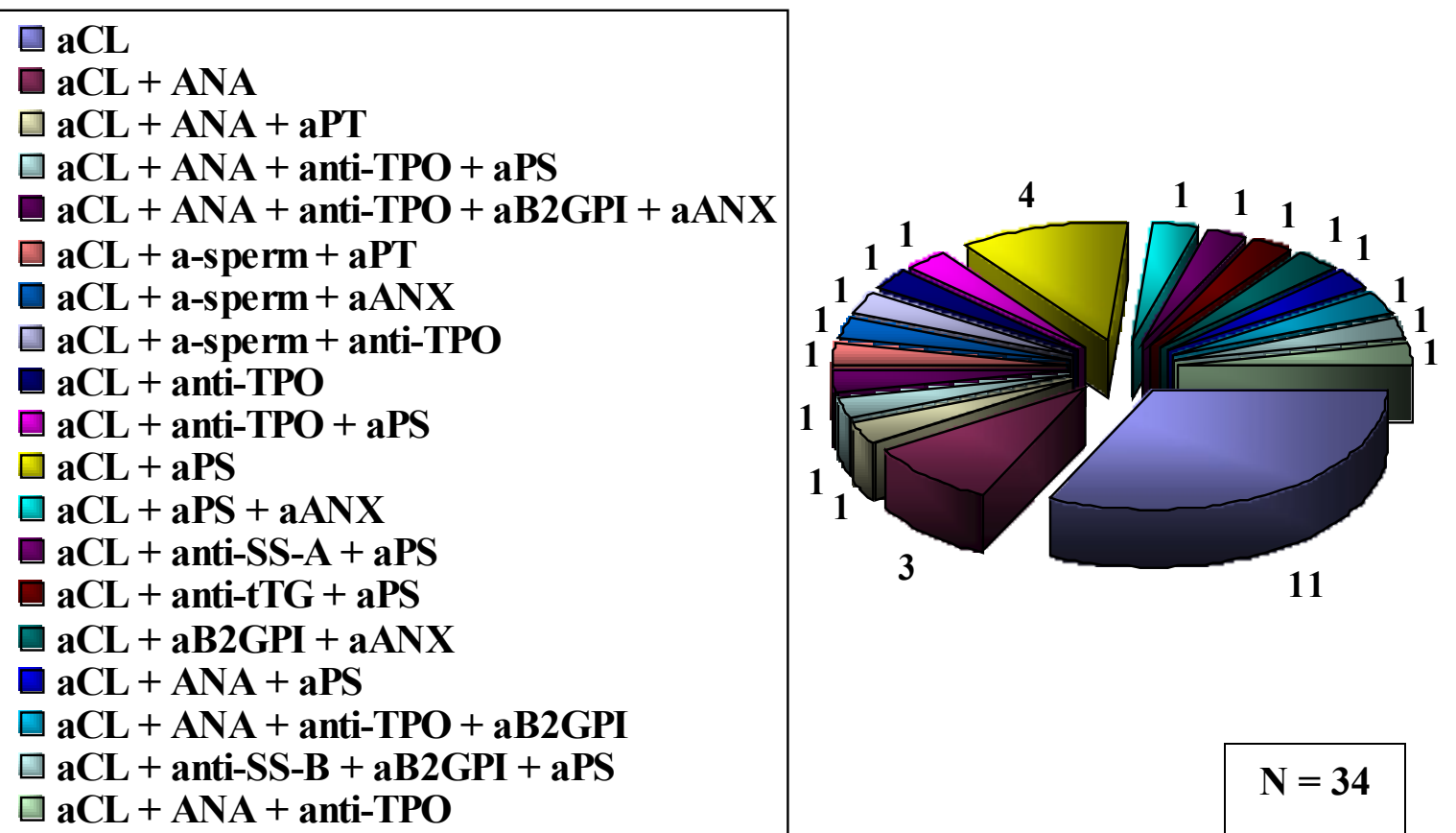

Figure 6: Patients with one-time aCL, associated antibodies and aPLs (N: number of patients)

Considering the laboratory criteria of APS we studied the occurence the aß2GPI antibody. Fifteen of the 500 (3.0\%) (st/if: 4/11) patients was aß2GPI positive. We detected this antibody in 9/15 females with aCL-positive and 6/15 patients was aCLnegative (Table IV).

The aß2GPI was established one-time in 10/15 cases and twice in 5/15 cases in addition to we could find 2/5 aCL-negative femals in twofold aß2GPI-positive group (Table IV). According to the clinical criteria of APS we could confirm 1 PAPS-patient (she was twofold aCL-positive too) and 2 SAPS-patiens, among them 1 was also one-time aCLpositive and 1 patient was only twice aß2GPI-positive (Table V).

Among 439 aCL-negative women, we found in 76/439 (17.3\%) patients not only aß2GPI antibody, but also such less frequent antibodies of APS (for instance aPS, aPT, aANX) too which not included in its laboratory criteria. The aß2GPI antibody was onetime positive in $2 / 76$ cases and twofold positive in 1/76 case. 


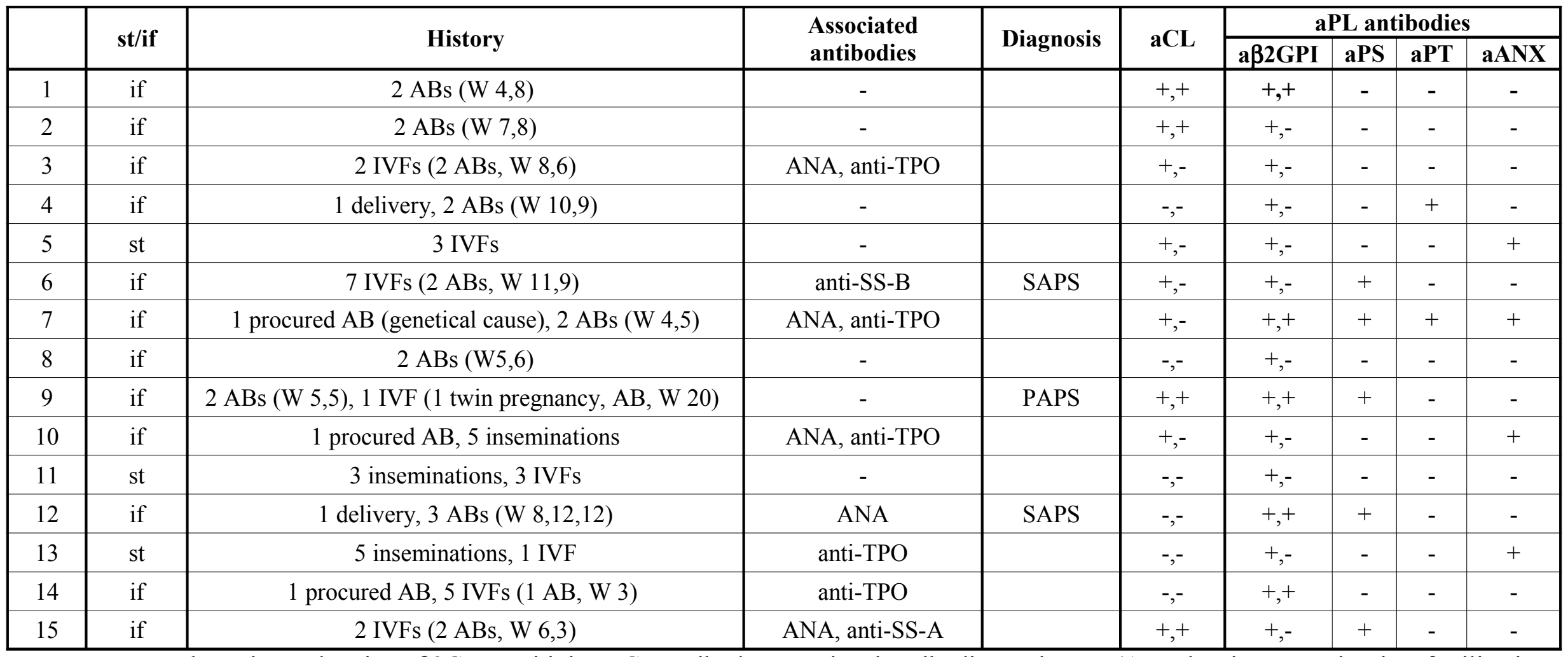

Table IV: Female patients showing aß2GPI positivity, aCL antibody, associated antibodies and aPLs (AB: abortion, IVF: in vitro fertilization, W: week) 
The aPS in itself was detected in 45/76 women, aPS with aß2GPI and aPS with aPT antibodies were verified equally in 1-1/76 patient. In six of 76 women aPS was detectable with together aANX antibody (Figure 7). We found the aPT in 1/76 case respectively and aPT with aß2GPI also in 1/76 woman. The aANX antibody alone was established in 16/439 patients and aANX along with aß2GPI was in 1/76 case. Finally, aPS with together aPT and aANX antibodies was detectable in 1/76 patient (Figure 7).

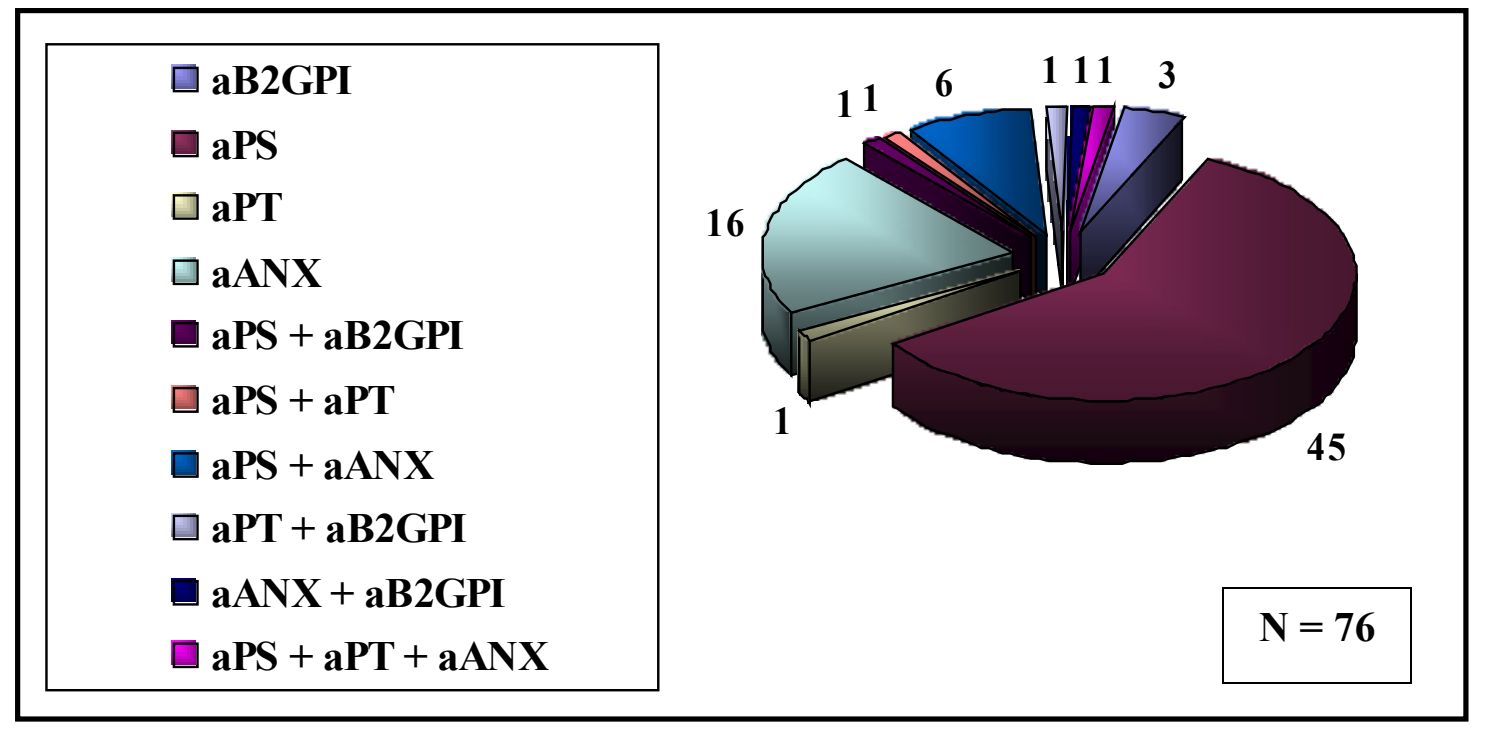

Figure 7: Patients with aCL negativity and less frequent aPLs (N: number of patients)

Summing up the results of our investigations - taking the clinical and laboratory criteria of APS into consideration - we could demonstrate the diagnosis of APS in 11/500 (2.2 $\%$ ) patients, there are 5/11 PAPS-patients and 6/11 SAPS-patients among them (Table $\mathrm{V})$.

Treatment in the follow-up period:

By the aPLs-positive patients we used the anticoagulant treatment, namely:

1. Administration of ASA (100 mg/day orally up to week 28 of gestation) alone, when the patient was aPLs-positive but the clinical picture and/or laboratory criteria did not fulfil the diagnostic criteria of APS or the patient rejected the anticoagulant injection.

2. Administration of maintenance dose LMWH (100 U/kg/day subcutaneous up to the delivery) alone, when the patient was allergic to acetylsalicylic acid or the pregnant suffered from hematoma around fetus or hemorrhage from uterus. 
3. Administration of ASA (100 mg/day orally up to week 28 of gestation) plus maintenance dose LMWH (100 U/kg/day subcutaneous up to the delivery).

In cases of SAPS or the patients with aPLs and antibodies of systemic autoimmune diseases and/or a-sperm antibody we completed the anticoagulant treatment with prednisolone $(20 \mathrm{mg} /$ day orally in the first trimester and then tapered to a maintenance dose of $5 \mathrm{mg} /$ day) too. When patients suffered from autoimmune thyroiditis (and/or latent hypothyroidism) the anticoagulant cure was completed levothyroxine too (Table $\mathrm{VI})$.

Among the twofold aCL-positive patients 22 conceptions were develop, itemized: $2 / 22$ ABs and 19/22 deliveries such as 15/19 spontaneous (sp) developed pregnancies and 4/19 pregnancies apropos of in vitro fertilization (IVF) / insemination. In addition 1/22 pregnancy is currently in progress. Furthermore 3 females were pregnant twice and there were 2 twin-pregnancies (Table VI).

In the group of females with once-time aCL positivity we could detect 15 pregnancies, namely 3/15 ABs, 12/15 child-births (8/12 sp developed pregnancies and 4/12 IVF/insem pregnancies) and 1 twin-pregnancy (Table VI).

When the aCL antibody was negative, but aß2GPI or other less frequent antibody of APS (for instance aPS, aPT, aANX) was positive, in the follow-up period there were 52 conceptions: 13/52 ABs, 32/52 deliveries (27/32 sp developed pregnancies and 5/32 IVF/insem pregnancies), 7/52 pregnancies are currently in progress (6/7 sp developed pregnancies, 1/7 IVF/insem pregnancy). In addition 3 women were pregnant twice and 5 pregnancies resulted twins (Table VII).

Lastly, among patients with together more aPLs 8 conceptions occcured such as $1 / 8 \mathrm{AB}$, 6/8 labours (4/6 sp developed pregnancies and 2/6 IVF/insem pregnancies), 1/8 pregnancy is currently in progress and 1 twin-pregnancy was presented (Table VIII). 


\begin{tabular}{|c|c|c|c|c|c|c|c|c|c|}
\hline & \multirow[b]{2}{*}{ st/if } & \multirow{2}{*}{ History } & \multirow{2}{*}{$\begin{array}{l}\text { Associated } \\
\text { antibodies }\end{array}$} & \multirow[b]{2}{*}{ Diagnosis } & \multirow[b]{2}{*}{$\mathbf{a C L}$} & \multicolumn{4}{|c|}{ aPL antibodies } \\
\hline & & & & & & aß2GPI & aPS & aPT & aANX \\
\hline 1 & if & 2 ABs (W 6,10) & - & PAPS &,++ &,-- & - & - & - \\
\hline 2 & if & 3 ABs (W 12,10,4) & a-sperm & SAPS &,++ &,-- & - & - & - \\
\hline 3 & if & $2 \mathrm{ABs}(\mathrm{W} 6,10)$ & - & PAPS &,++ &,-- & - & - & + \\
\hline 4 & if & 2 deliveries, 3 ABs (W 13,6,7) & anti-dsDNA, a-sperm & SAPS &,++ &,-- & - & - & - \\
\hline 5 & if & 2 ABs (W 6,10) & a-sperm & SAPS &,++ &,+- & - & - & + \\
\hline 6 & if & 2 ABs (W 5,5), 1 IVF (1 twin pregnancy, AB, W 20) & - & PAPS &,++ &,++ & + & - & - \\
\hline 7 & if & I. 2 delivery, II. 3 ABs (W 4,7,7) & anti-dsDNA & SAPS &,++ &,-- & + & - & - \\
\hline 8 & if & 2 IVFs, 1 still-birth (W 29) & - & PAPS &,+- &,-- & - & - & - \\
\hline 9 & if & $1 \mathrm{AB}$ (W 24), 6 IVFs & - & PAPS &,+- &,-- & - & - & - \\
\hline 10 & if & 7 IVFs (2 ABs, W 11,9) & anti-SS-B & SAPS &,+- &,+- & + & - & - \\
\hline 11 & if & 1 delivery, 3 ABs (W 8,12,12) & ANA & SAPS &,-- &,++ & + & - & - \\
\hline
\end{tabular}

Table V: Considering the clinical and laboratory criteria of APS these patients suffer from PAPS or SAPS (AB: abortion, IVF: in vitro fertilization, W: week) 


\begin{tabular}{|c|c|c|c|c|c|c|c|c|c|}
\hline \multirow[b]{2}{*}{ Patients (N) } & \multirow[b]{2}{*}{ Therapy } & \multirow[b]{2}{*}{$\begin{array}{c}\text { Conception } \\
\text { (all) }\end{array}$} & \multirow[b]{2}{*}{ Abortion } & \multicolumn{2}{|c|}{ Delivery } & \multicolumn{2}{|c|}{ Pregnancy } & \multicolumn{2}{|c|}{ Pregnancy/Delivery } \\
\hline & & & & sp & $\begin{array}{c}\text { IVF, } \\
\text { insem }\end{array}$ & $\mathbf{s p}$ & $\begin{array}{c}\text { IVF, } \\
\text { insem }\end{array}$ & Twice & Twin \\
\hline \multirow{5}{*}{$\mathrm{aCL}(+/+)(27 / 500)$} & ASA & 6 & - & $3 / 6$ & $3 / 6$ & - & - & 2 & 1 \\
\hline & $\mathrm{ASA}+\mathrm{LMWH}$ & 9 & $1 / 9$ & $7 / 9$ & $1 / 9$ & - & - & - & 1 \\
\hline & ASA + levothyroxine & 2 & - & $2 / 2$ & - & - & - & - & - \\
\hline & ASA + LMWH + levothyroxine & 1 & - & - & - & $1 / 1$ & - & - & - \\
\hline & prednisolone & 4 & $1 / 4$ & $3 / 4$ & - & - & - & 1 & - \\
\hline Summary & - & 22 & $2 / 22$ & $15 / 22$ & $4 / 22$ & $1 / 22$ & $\mathbf{0} / \mathbf{2 2}$ & 3 & 2 \\
\hline \multirow{6}{*}{$\mathrm{aCL}(+/-)(34 / 500)$} & ASA & 5 & - & $1 / 5$ & $4 / 5$ & - & - & & $1 / 1$ \\
\hline & ASA + LMWH & 7 & $1 / 7$ & $6 / 7$ & - & - & - & - & - \\
\hline & ASA + levothyroxine & 1 & - & - & - & - & - & - & - \\
\hline & LMWH & 1 & $1 / 1$ & - & - & - & - & - & - \\
\hline & ASA + prednisolone & 1 & $1 / 1$ & - & - & - & - & - & - \\
\hline & ASA + gluten-free diet & 1 & - & $1 / 1$ & - & - & - & - & - \\
\hline Summary & - & 15 & $3 / 15$ & $8 / 15$ & $4 / 15$ & $0 / 15$ & $0 / 15$ & $\mathbf{0}$ & 1 \\
\hline
\end{tabular}

Table VI: Pregnancies, deliveries and abortions among patients with twofold and once-time aCL positivity (N: number of patients)

\begin{tabular}{|c|c|c|c|c|c|c|c|c|c|}
\hline \multirow[b]{2}{*}{ Patients (N) } & \multirow[b]{2}{*}{ Therapy } & \multirow[b]{2}{*}{$\begin{array}{c}\text { Conception } \\
\text { (all) }\end{array}$} & \multirow[b]{2}{*}{ Abortion } & \multicolumn{2}{|c|}{ Delivery } & \multicolumn{2}{|c|}{ Pregnancy } & \multicolumn{2}{|c|}{ Pregnancy/Delivery } \\
\hline & & & & sp & $\begin{array}{c}\text { IVF, } \\
\text { insem }\end{array}$ & sp & $\begin{array}{l}\text { IVF, } \\
\text { insem }\end{array}$ & Twice & Twin \\
\hline$\beta 2 \mathrm{GPI}(3 / 76)$ & ASA & 3 & - & $3 / 3$ & - & - & - & 1 & - \\
\hline \multirow[t]{2}{*}{ aPS (45/76) } & ASA & 6 & - & $4 / 6$ & $1 / 6-$ & $1 / 6$ & - & 1 & 1 \\
\hline & ASA + LMWH & 16 & $3 / 16$ & $9 / 16$ & & $3 / 16$ & $1 / 16$ & - & 1 \\
\hline
\end{tabular}




\begin{tabular}{|c|c|c|c|c|c|c|c|c|c|}
\hline & ASA + levothyroxine & 5 & $5 / 5$ & - & - & - & - & - & - \\
\hline & LMWH & 1 & - & $1 / 1$ & - & - & - & - & - \\
\hline & ASA + LMWH + levothyroxine & 2 & - & $1 / 2$ & - & $1 / 2$ & - & - & - \\
\hline & ASA + LMWH + prednisolone & 1 & - & $1 / 1$ & - & - & - & - & - \\
\hline & LMWH + prednisolone & 1 & - & - & - & $1 / 1$ & - & - & - \\
\hline & prednisolone & 1 & $1 / 1$ & - & - & - & - & - & - \\
\hline \multirow{5}{*}{ aANX (16/76) } & $\mathrm{ASA}$ & 2 & - & $1 / 2$ & $1 / 2$ & - & - & - & 1 \\
\hline & $\mathrm{ASA}+\mathrm{LMWH}$ & 7 & - & $6 / 7$ & $1 / 7$ & - & - & 1 & 1 \\
\hline & ASA + levothyroxine & 2 & $1 / 2$ & - & $1 / 2$ & - & - & - & 1 \\
\hline & ASA + LMWH + levothyroxine & 2 & - & $1 / 2$ & $1 / 2$ & - & - & - & - \\
\hline & ASA + gluten-free diet & 2 & $2 / 2$ & - & - & - & - & - & - \\
\hline aPT $(1 / 76)$ & $\mathrm{ASA}$ & 1 & $1 / 1$ & - & - & - & - & - & - \\
\hline Summary & - & 52 & $13 / 52$ & $27 / 52$ & $5 / 52$ & $6 / 52$ & $1 / 52$ & 3 & 5 \\
\hline
\end{tabular}

Table VII: Pregnancies, deliveries and abortions among aCL-negative patients with an aPL antibody (N: number of patients)

\begin{tabular}{|c|c|c|c|c|c|c|c|c|c|}
\hline \multirow[b]{2}{*}{ Patients (N) } & \multirow[b]{2}{*}{ Therapy } & \multirow[b]{2}{*}{$\begin{array}{c}\text { Conception } \\
\text { (all) }\end{array}$} & \multirow[b]{2}{*}{ Abortion } & \multicolumn{2}{|c|}{ Delivery } & \multicolumn{2}{|c|}{ Pregnancy } & \multicolumn{2}{|c|}{ Pregnancy/Delivery } \\
\hline & & & & $\mathbf{s p}$ & $\begin{array}{c}\text { IVF, } \\
\text { insem }\end{array}$ & sp & $\begin{array}{c}\text { IVF, } \\
\text { insem }\end{array}$ & Twice & Twin \\
\hline $\mathrm{aPS}+\mathrm{a} \beta 2 \mathrm{GPI}(1 / 76)$ & ASA + LMWH & 1 & - & $1 / 1$ & - & - & - & - & - \\
\hline $\mathrm{aPS}+\mathrm{aPT}+\mathrm{aANX}(1 / 76)$ & ASA + LMWH + levothyroxine & 1 & - & $1 / 1$ & - & - & - & - & - \\
\hline \multirow{2}{*}{$\mathrm{aPS}+\mathrm{aANX}(6 / 75)$} & ASA & 1 & $1 / 1$ & - & - & - & - & - & - \\
\hline & ASA + LMWH & 5 & - & $2 / 5$ & $2 / 5$ & $1 / 5$ & - & - & 2 \\
\hline Summary & - & 8 & $1 / 8$ & $4 / 8$ & $2 / 8$ & $1 / 8$ & $\mathbf{0} / \mathbf{8}$ & - & 2 \\
\hline
\end{tabular}

Table VIII: Pregnancies, deliveries and abortions among aCL-negative patients with aPLs (N: number of patients) 


\section{ANTIBODIES OF THE SYSTEMIC AUTOIMMUNE DISEASES IN RELATION TO REPRODUCTIVE FAILURES}

\section{Aims}

The aim was to examine female patients for the systemic autoimmune diseases apart from APS and determine prevalence of autoantibodies such as ANA, anti-dsDNA, antiJo-1, anti-Sm, anti-RNP, anti-SS-A and anti-SS-B.

\section{Results}

The auto-antibodies for the systemic autoimmune diseases could be establish in 151/500 $(30.2 \%)$ patients (Figure 8, 9, 10).

In 66/500 (13.2\%) females these antibodies were detected without other autoantibodies for instance aPLs, anti-tTG, and anti-TPO (Figure 8). Among them we found ANA in itself in 52/66 women, furthermore ANA with anti-Sm, ANA with anti-SS-A and ANA with anti-Jo-1 antibodies were detectable equally in 1-1-1/66 patient. We verified ANA with together anti-SS-A and anti-Sm antibodies and ANA with together anti-SS-A and anti-SS-B antibodies in 1-1/66 case (Figure 8).

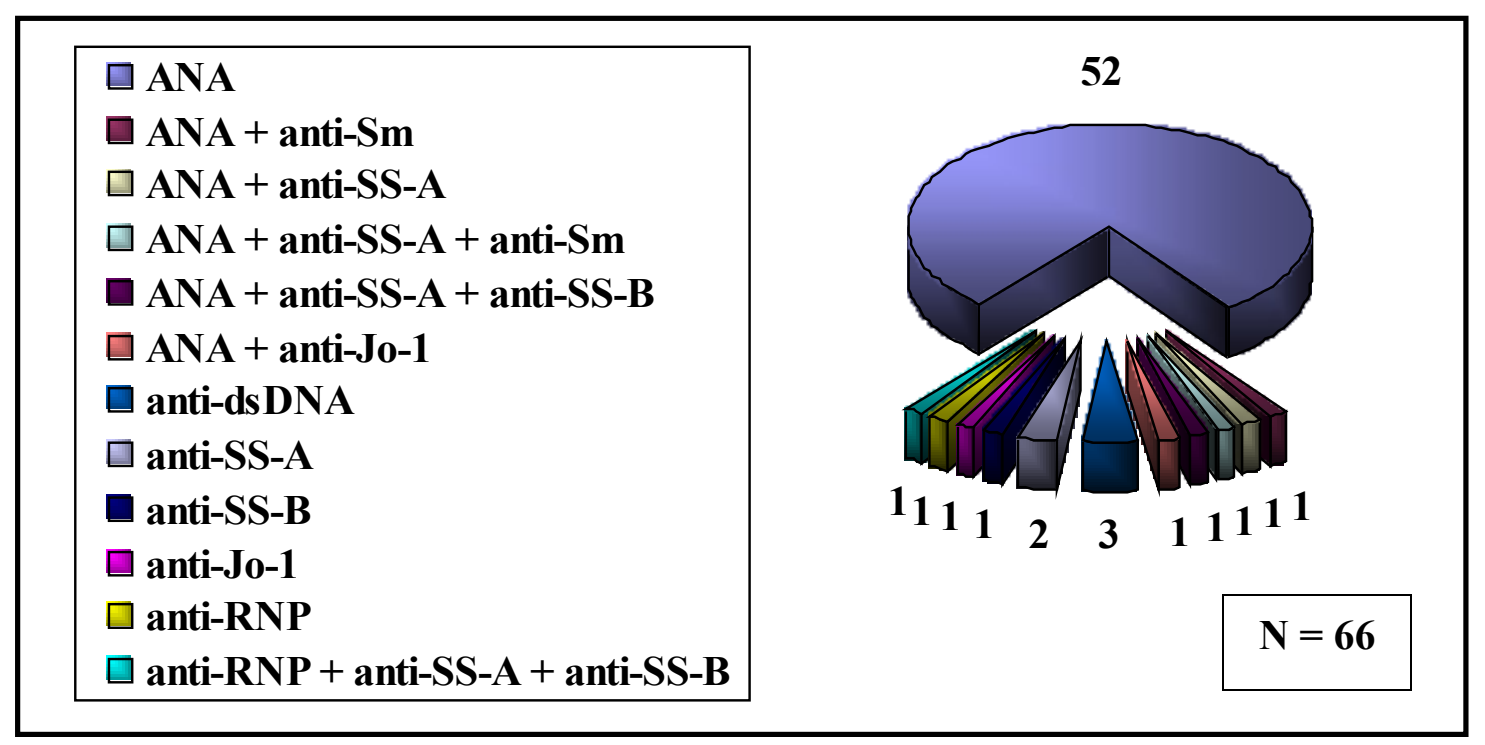

Figure 8: Patients with auto-antibodies of the systemic autoimmune diseases only (N: number of patients)

The anti-SS-A antibody could be establish in 2/66 patients, in addition to anti-SS-B, anti-Jo-1 and anti-RNP antibodies were found in 1-1-1/66 female respectively. In 3/66 
patients the anti-dsDNA antibody in itself was presented. Finally, anti-RNP along with anti-SS-A and anti-SS-B antibodies were detectable in 1/66 patient (Figure 8).

In $85 / 500(17.0 \%)$ women the auto-antibodies of the systemic autoimmun diseases could be verify with together aPLs or auto-antibodies for organ-specific autoimmune diseases or a-sperm antibody (Figure 9, 10).

We could find mostly ANA (64/85), anti-dsDNA (9/85), and anti-SS-A (7/85) autoantibodies with each other and/or aPLs and/or antibodies of the organ-specific autoimmune diseases and/or a-sperm antibody such as (Figure 9, 10):

- ANA + aCL (+/-): 10/85 patients

- ANA + anti-dsDNA + aCL (+/-): 1/85 patient

- ANA + anti-TPO + aCL (+/+): 2/85 patients

- ANA + a-sperm + anti-TPO: 1/85 patient

- ANA + aCL (+/+): 1/85 patient

- ANA + a-sperm + aCL (+/-): 1/85 patient

- ANA + anti-TPO + aCL (+/-) + aß2GPI (+/-): 1/85 patient

- ANA + aß2GPI (+/-) + aANX: 1/85 patient

- ANA + anti-dsDNA + a-sperm + anti-TPO: 1/85 patient

- ANA + anti-TPO: 8/85 patients

- ANA + aPS: 6/85 patients

- ANA + anti-TPO + aCL (+/-) + aß2GPI (+/+): 1/85 patient

- ANA + anti-SS-A + anti-TPO: 1/85 patient

- ANA + anti-SS-A + anti-Sm + anti- TPO: 1/85 patient

- ANA + anti-TPO + aPS + aPT + aANX: 1/85 patient

- ANA + aPS + aANX: 2/85 patients

- ANA + anti-TPO + aCL (+/-) + aPS: 1/85 patient

- ANA + aANX: $2 / 85$ patients

- ANA + anti-TPO + aANX: 1/85 patient

- ANA + anti-Sm + anti-TPO: 1/85 patient

- ANA + aCL (+/-) + aPS: 1/85 patient

- ANA + a-sperm: 3/85 patients

- ANA + anti-SS-B + anti-TPO + a-sperm: 1/85 patient

- ANA + anti-TPO + aCL (+/-) + aß2GPI (+/-) + aANX: 1/85 patient

- ANA + anti-Sm + anti-TPO + aANX: 2/85 patients 
- ANA + anti-tTG: $2 / 85$ patients

- ANA + aß2GPI (+/-) + aPS: 1/85 patient

- ANA + anti-Sm + aPS: 1/85 patient

- ANA + anti-dsDNA + aPS: 1/85 patient

- ANA + anti-TPO + aPS: 2/85 patients

- ANA + anti-SS-A + aPS: 2/85 patients

- ANA + anti-SS-A + aCL (+/+) + aß2GPI (+/-) + aPS: 1/85 patient

- ANA + anti-RNP + anti-TPO: 1/85 patient

- ANA + anti-RNP + anti-TPO + aPS: 1/85 patient

- anti-dsDNA + aCL (+/+): 1/85 patient

- anti-dsDNA + a-sperm + aCL (+/+): 1/85 patient

- anti-dsDNA + anti-TPO + aCL (+/+): 1/85 patient

- anti-dsDNA + anti-tTG + a-sperm: 1/85 patient

- anti-dsDNA + anti-TPO: 3/85 patients

- anti-dsDNA + a-sperm + aCL (+/-): 1/85 patient

- anti-dsDNA + aCL (+/+) + aPS: 1/85 patient

- anti-SS-A + anti-TPO: 1/85 patient

- anti-SS-A + aCL (+/-) + aPS: 1/85 patient

- anti-SS-A + a-sperm: 2/85 patients

- anti-SS-A + anti-TPO + aPS: 2/85 patients

- anti-SS-A + anti-SS-B + anti-tTG: 1/85 patient

Finally, in three of the 85 cases anti-Sm and in 2/85 females anti-SS-B antibody could be establish along with further antibodies such as (Figure 10):

- anti-Sm + a-sperm: 1/85 patient

- anti-Sm + anti-TPO + aPS: 1/85 patient

- anti-Sm + anti-SS-A + anti-SS-B + aCL (+/-): 1/85 patient

- anti-SS-B + aCL (+/-) + aß2GPI (+/-) + aPS: 1/85 patient

- anti-SS-B + anti-RNP + anti-TPO: 1/85 patient 


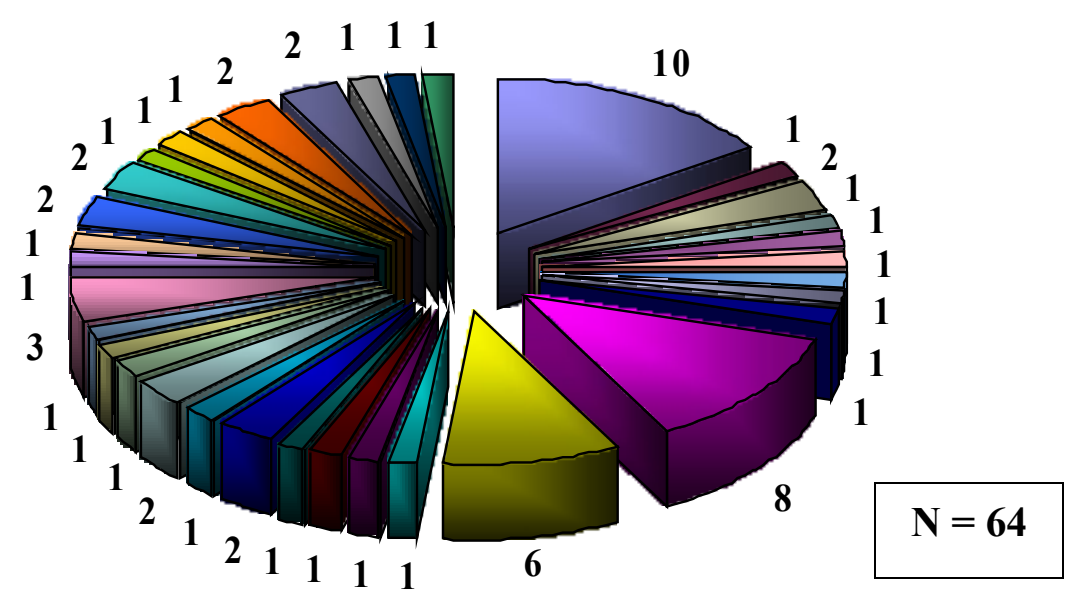

ANA + aCL (+/-)

ANA + anti-dsDNA + aCL (+/-)

$\square$ ANA + anti-TPO + aCL (+/+)

$\square$ ANA + a-sperm + anti-TPO

$\square$ ANA + aCL (+/+)

$\square$ ANA + a-sperm + aCL (+/-)

$\square$ ANA + anti-TPO + aCL (+/-) + aB2GPI (+/-)

$\square$ ANA + aB2GPI (+/-) + aANX

ANA + anti-dsDNA + a-sperm + anti-TPO

$\square$ ANA + anti-TPO

$\square \mathrm{ANA}+$ aPS

$\square$ ANA + anti-TPO + aCL (+/-) + aB2 GPI (+/+)

口ANA + anti-SS-A + anti-TPO

a ANA + anti-SS-A + anti-Sm + anti-TPO

$\square \mathrm{ANA}+$ anti-TPO + aPS + aPT + aANX

D ANA + aPS + aANX

$\square$ ANA + anti-TPO + aCL (+/-) + aPS

$\square$ ANA + aANX

$\square$ ANA + anti-TPO + aANX

$\square$ ANA + anti-Sm + anti-TPO

$\square$ ANA + aCL (+/-) + aPS

$\square$ ANA + a-sperm

$\square$ ANA + anti-SS-B + anti-TPO + a-sperm

$\square$ ANA + anti-TPO + aCL (+/-) + aB2 GPI (+/-) + aANX

$\square$ ANA + anti-Sm + anti-TPO + aANX

$\square$ ANA + anti-tTG

$\square$ ANA + aB2GPI (+/-) + aPS

$\square$ ANA + anti-Sm + aPS

$\square$ ANA + anti-dsDNA + aPS

$\square$ ANA + anti-TPO + aPS

$\square$ ANA + anti-SS-A + aPS

$\square$ ANA + anti-SS-A + aCL (+/+) + aB2 GPI (+/-) + aPS

口 ANA + anti-RNP + anti-TPO

$\square$ ANA + anti-RNP + anti-TPO + aPS

Figure 9: Patients with ANA antibody and other antibodies (N: number of patients) 


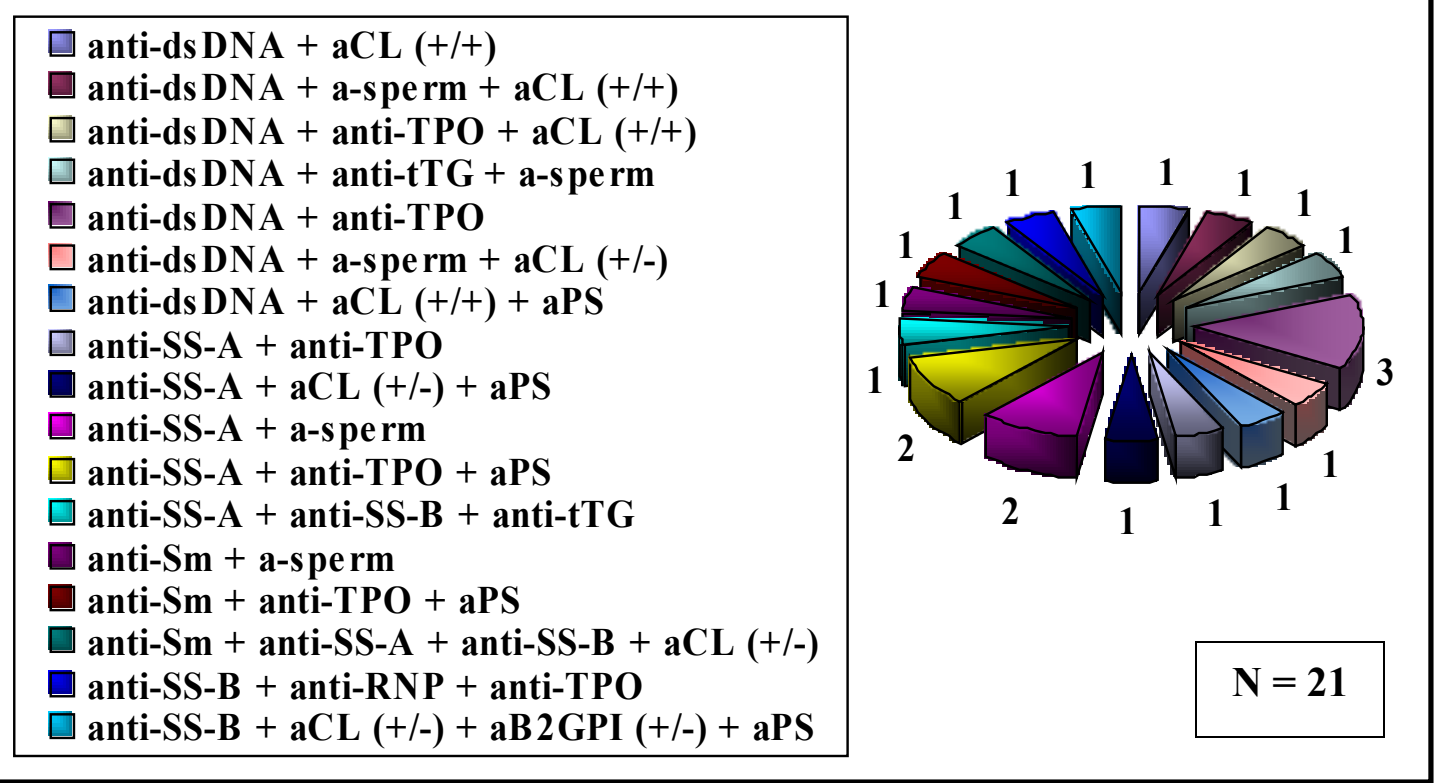

Figure 10: Patients with auto-antibodies of the systemic autoimmune diseases (apart from ANA) and other antibodies (N: number of patients)

Treatment in the follow-up period:

In cases of patients with antibodies of systemic autoimmune diseases we applied not only prednisolone $(20 \mathrm{mg} /$ day orally in the first trimester and then tapered to a maintenance dose of $5 \mathrm{mg} /$ day) but also anticoagulant treatment (the same as in the aPLs-positive patients) too. Thanks to application of these medications we could detected 29 conception among these patients, itemized: 5/29 ABs, 22/29 child-births (18/22 sp developed pregnancies and 4/22 IVF/insem pregnancies), 2/29 pregnancies are currently in progress (1/2 sp developed pregnancy, 1/2 IVF/insem pregnancy). Moreover 3 women were pregnant twice and 1 pregnancy resulted twins (Table IX).

Among such women, who had got not only antibodies of systemic autoimmune diseases but also aPLs, antibodies of organ-specific autoimmune diseases and/or a-sperm antibody, the types of treatment and obstetrical results are represented in other chapters of dissertation. 


\begin{tabular}{|c|c|c|c|c|c|c|c|c|c|}
\hline \multirow[b]{2}{*}{ Patients (N) } & \multirow[b]{2}{*}{ Therapy } & \multirow[b]{2}{*}{$\begin{array}{c}\text { Conception } \\
\text { (all) }\end{array}$} & \multirow[b]{2}{*}{ Abortion } & \multicolumn{2}{|c|}{ Delivery } & \multicolumn{2}{|c|}{ Pregnancy } & \multicolumn{2}{|c|}{ Pregnancy/Delivery } \\
\hline & & & & sp & $\begin{array}{c}\text { IVF, } \\
\text { insem }\end{array}$ & sp & $\begin{array}{l}\text { IVF, } \\
\text { insem }\end{array}$ & Twice & Twin \\
\hline \multirow{5}{*}{ ANA $(52 / 66)$} & $\overline{\mathrm{ASA}}$ & 5 & - & $4 / 5$ & - & $1 / 5$ & - & - & - \\
\hline & ASA + LMWH & 3 & - & $2 / 3$ & - & - & $1 / 3$ & - & - \\
\hline & ASA + prednisolone & 2 & - & $1 / 2$ & $1 / 2$ & - & - & - & - \\
\hline & LMWH & 2 & $2 / 2$ & - & - & - & - & - & - \\
\hline & prednisolone & 8 & $1 / 8$ & $7 / 8$ & - & - & - & 1 & 1 \\
\hline ANA + anti-Sm (1/66) & prednisolone & 1 & - & $1 / 1$ & - & - & - & - & - \\
\hline ANA + anti-SS-A $(1 / 66)$ & prednisolone & 2 & - & - & $2 / 2$ & - & - & 2 & - \\
\hline ANA + anti-Jo-1 (1/66) & prednisolone & 1 & - & $1 / 1$ & - & - & - & - & - \\
\hline ANA + anti-SS-A + anti-Sm (1/66) & prednisolone & 1 & - & - & $1 / 1$ & - & - & - & - \\
\hline \multirow{2}{*}{ anti-dsDNA $(3 / 66)$} & ASA + prednisolone & 1 & $1 / 1$ & - & - & - & - & - & - \\
\hline & ASA & 1 & $1 / 1$ & - & - & - & - & - & - \\
\hline anti-SS-A (1/66) & prednisolone & 1 & - & $1 / 1$ & - & - & - & - & - \\
\hline anti-RNP (1/66) & $\overline{\mathrm{ASA}}$ & 1 & - & $1 / 1$ & - & - & - & - & - \\
\hline Summary & - & 29 & $5 / 29$ & $18 / 29$ & $4 / 29$ & $1 / 29$ & $1 / 29$ & 3 & 1 \\
\hline
\end{tabular}

Table IX: Pregnancies, deliveries and abortions among patients with antibodies of systemic autoimmune diseases (N: number of patients) 


\section{AUTOIMMUNE THYROIDITIS AND THYROID DISFUNCTION IN RELATION TO REPRODUCTIVE FAILURES}

\section{Aims}

The aim was to verify the presence of autoimmune thyroiditis and thyroid disfunction among female patients with reproductive failures.

\section{Results}

The anti-TPO as the organ-specific auto-antibody of the autoimmune thyroiditis was detectable in $71 / 500(14.2 \%)$ women, among them 52/71 patients were euthyroid and the further 19/71 patients suffered from latent hypothyroidism (Figure 11, 12).

Among the 19/71 patients suffered from latent hypothyroidism the anti-TPO in itself was detected in 9/19 women and we verified another sort of antibodies along with antiTPO such as (Figure 11):

- anti-TPO + ANA: 2/19 patients

- anti-TPO + ANA + anti-SS-A + anti-Sm: 1/19 patient

- anti-TPO + ANA + anti-RNP: 1/19 patient

- anti-TPO + ANA + aCL (+/+): 1/19 patient

- anti-TPO + ANA + anti-SS-B + a-sperm: 1/19 patient

- anti-TPO + anti-dsDNA + aCL (+/+): 1/19 patient

- anti-TPO + anti-SS-A: 1/19 patient

- anti-TPO + anti-RNP + anti-SS-B: 1/19 patient

- anti-TPO + aPS + anti-tTG: 1/19 patient

\footnotetext{
$\square$ anti-TPO

$\square$ anti-TPO + ANA

$\square$ anti-TPO + ANA + anti-SS-A + anti-Sm

$\square$ anti-TPO + ANA + anti-RNP

$\square$ anti-TPO + ANA + aCL (+/+)

$\square$ anti-TPO + ANA + anti-SS-B + a-sperm

$\square$ anti-TPO + anti-ds DNA + aCL (+/+)

$\square$ anti-TPO + anti-SS-A

anti-TPO + anti-RNP + anti-SS-B

$\square$ anti-TPO + aPS + anti-tTG
}

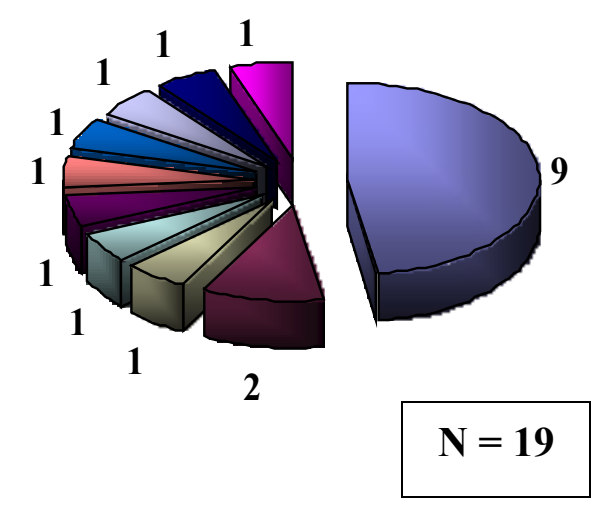

Figure 11: Patients with anti-TPO and latent hypothyroidism (N: number of patients) 
In 18/52 euthyroid cases the anti-TPO antibody could be established in itself, moreover in this group we studied other auto-antibodies of the systemic autoimmune and organspecific autoimmune diseases, aPLs and a-sperm antibody too. In our study, we could detect anti-TPO with together ANA in 5/52 patients, in 11/52 cases not only anti-TPO and ANA antibodies were detectable but also other antibodies, namely (Figure 12):

- anti-TPO + ANA + aCL (+/+): 1/52 patient

- anti-TPO + ANA + a-sperm: 1/52 patient

- anti-TPO + ANA + anti-SS-A: 1/52 patient

- anti- TPO + ANA + anti-Sm: 1/52 patient

- anti-TPO + ANA + anti-RNP: 1/52 patient

- anti-TPO + ANA + aPS: 1/52 patient

- anti-TPO + ANA + aCL (+/-) + aß2GPI (+/-): 1/52 patient

- anti-TPO + ANA + aCL (+/-) + aPS: 1/52 patient

- anti-TPO + ANA + aCL (+/-) + aß2GPI (+/+) + aPS + aPT + aANX: 1/52 patient

- anti-TPO + ANA + anti-Sm + anti-tTG + aANX: 1/52 patient

- anti-TPO + ANA + anti-dsDNA + a-sperm: 1/52 patient

Investigating of antibodies of the systemic autoimmune diseases except the ANA in 3/52 women we could confirm anti-TPO antibody along with anti-dsDNA, anti-Sm and anti-SS-A such as (Figure 12):

- anti-TPO + anti-dsDNA: 3/52 patients

- anti-TPO + anti-Sm + aPS: 1/52 patient

- anti-TPO + anti-SS-A + aPS: 1/52 patient

As far as aPLs are concerned, including aCL and aANX antibodies were present equally in 2-2/52 patients, as well as a $32 \mathrm{GPI}$ and aPS antibodies were verified in 1-1/52 case with together anti-TPO and we observed coexistence of two aPLs too (Figure 12):

- anti-TPO + aCL (+/-) + aPS: 1/52 patient

- anti-TPO + aß2GPI (+/-) + aANX: 1/52 patient

- anti-TPO + aPS + aANX: 1/52 patient

In respect to the organ-specific auto-antibodies, the anti-tTG with anti-TPO was verified in 1/52 case. Last but not least, anti-TPO with a-sperm antibody could be detect in 2/52 patients furthermore anti-TPO with together a-sperm and aCL antibodies was detected in $1 / 52$ case (Figure 12). 


$$
\mathbf{N}=\mathbf{5 2}
$$



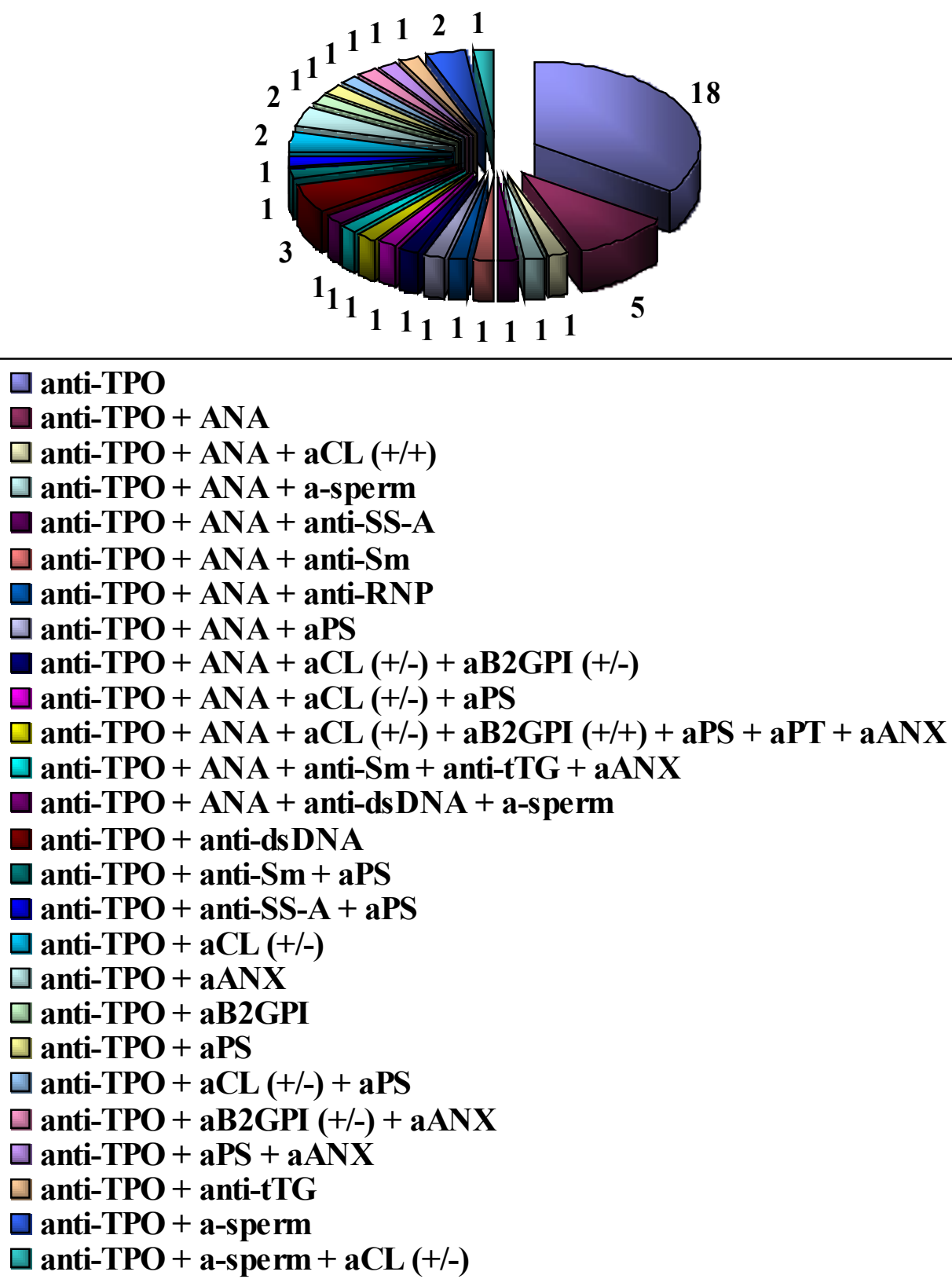

Figure 12: Patients with anti-TPO and euthyroidism (N: number of patients)

In our results we noticed 18/500 (3.6\%) women suffering from latent hypothyroidism without anti-TPO antibody and what is more among them there are 9/18 patients without any antibodies. However in further 9/18 females with latent hypothyreosis we could find other antibodies (Figure 13):

- latent hypothyroidism + aCL $(+/+): 2 / 18$ patients

- latent hypothyroidism + aCL (+/-): $1 / 18$ patient

- latent hypothyroidism $+\mathrm{aCl}(+/-)+$ aPS: $1 / 18$ patient

- latent hypothyroidism + ANA: 2/18 patients 
- latent hypothyroidism + ANA + aPS: $1 / 18$ patient

- latent hypothyroidism + ANA + anti-tTG: 1/18 patient

- latent hypothyroidism + anti-dsDNA + aCL $(+/-)+$ a-sperm: 1/18 patient

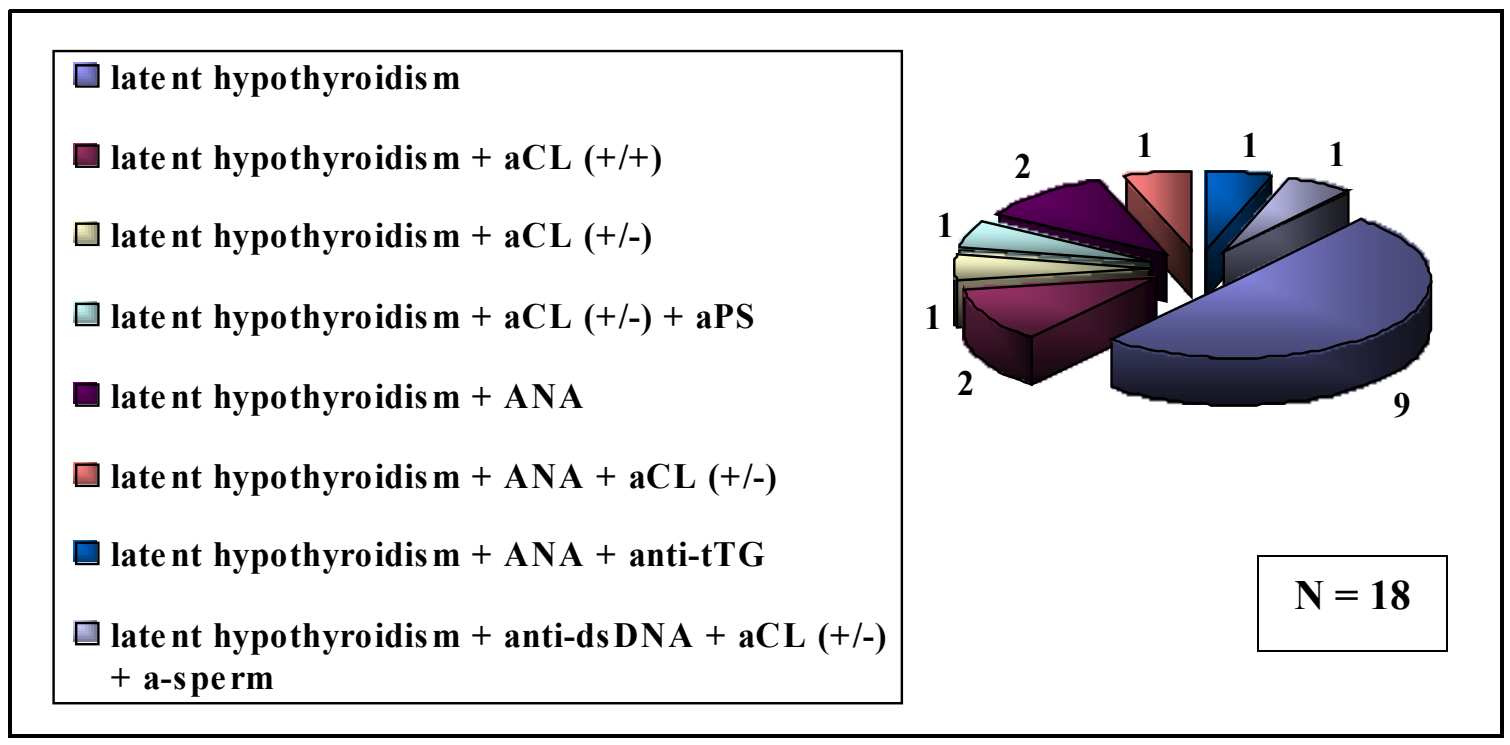

Figure 13: Patients with latent hypothyroidism without anti-TPO antibody (N: number of patients)

\section{Treatment in the follow-up period:}

Among patients suffered from latent hypothyroidism with or without anti-TPO antibody we could cure with levothyroxine (starting with a dose of $25 \mu \mathrm{g} /$ day orally, and adjusted according to the TSH-hormone findings when required).

Among 9/18 patients with latent hypothyroidism without anti-TPO and other antibodies 1 patient with levothyroxine plus ASA had got 2 child-births (sp developed pregnancies) and in this group levothyroxine alone resulted further 3 deliveries (sp developed pregnancies).

In cases of patients with autoimmune thyroiditis and latent hypothyroidism along with antibodies of systemic autoimmune diseases and a-sperm we could 14 conceptions were presented, from them there were 4/14 ABs, 8/14 labour (5/8 sp developed pregnancies and 3/8 IVF/insem pregnancies), 2/14 pregnancies are currently in progress. Moreover 1 female was pregnant twice and 1 pregnancy resulted twins (Table X). 


\begin{tabular}{|c|c|c|c|c|c|c|c|c|c|}
\hline \multirow[b]{2}{*}{ Patients (N) } & \multirow[b]{2}{*}{ Therapy } & \multirow{2}{*}{$\begin{array}{l}\text { Conception } \\
\text { (all) }\end{array}$} & \multirow[b]{2}{*}{ Abortion } & \multicolumn{2}{|c|}{ Delivery } & \multicolumn{2}{|c|}{ Pregnancy } & \multicolumn{2}{|c|}{ Pregnancy/Delivery } \\
\hline & & & & sp & $\begin{array}{l}\text { IVF, } \\
\text { insem }\end{array}$ & sp & $\begin{array}{l}\text { IVF, } \\
\text { insem }\end{array}$ & Twice & Twin \\
\hline \multirow{2}{*}{ anti-TPO $(9 / 19)$} & levothyroxine & 6 & $1 / 6$ & $4 / 6$ & $1 / 6$ & - & - & - & 1 \\
\hline & levothyroxine + ASA & 2 & $1 / 2$ & - & - & $1 / 2$ & - & - & - \\
\hline anti-TPO + ANA (2/19) & levothyroxine + ASA + LMWH & 1 & - & - & - & $1 / 1$ & - & - & - \\
\hline $\begin{array}{c}\text { anti-TPO + ANA } \\
+ \text { anti-SS-A + anti-Sm } \\
(1 / 19)\end{array}$ & levothyroxine + ASA & 1 & - & - & $1 / 1$ & - & - & - & - \\
\hline $\begin{array}{l}\text { anti-TPO + ANA } \\
+ \text { anti-RNP }(1 / 19)\end{array}$ & levothyroxine + ASA + LMWH & 1 & - & - & $1 / 1$ & - & - & - & - \\
\hline $\begin{array}{c}\text { anti-TPO + ANA } \\
+ \text { anti-SS-B + a-sperm } \\
(1 / 19) \\
\end{array}$ & levothyroxine + ASA & 1 & $1 / 1$ & - & - & - & - & - & - \\
\hline \multirow{2}{*}{$\begin{array}{c}\text { anti-TPO + anti-SS-A } \\
(1 / 19)\end{array}$} & levothyroxine & 1 & $1 / 1$ & - & - & - & - & \multirow{2}{*}{1} & - \\
\hline & levothyroxine + prednisolone & 1 & - & $1 / 1$ & - & - & - & & - \\
\hline Summary & - & 14 & $4 / 14$ & $5 / 14$ & $3 / 14$ & $2 / 14$ & - & 1 & 1 \\
\hline
\end{tabular}

Table X: Pregnancies, deliveries and abortions among patients with autoimmune thyroiditis and latent hypothyroidism along with antibodies of systemic autoimmune diseases and a-sperm (N: number of patients)

\begin{tabular}{|c|c|c|c|c|c|c|c|c|c|}
\hline \multirow[b]{2}{*}{ Patients (N) } & \multirow[b]{2}{*}{ Therapy } & \multirow{2}{*}{$\begin{array}{c}\text { Conception } \\
\text { (all) }\end{array}$} & \multirow[b]{2}{*}{ Abortion } & \multicolumn{2}{|c|}{ Delivery } & \multicolumn{2}{|c|}{ Pregnancy } & \multicolumn{2}{|c|}{ Pregnancy/Delivery } \\
\hline & & & & sp & $\begin{array}{c}\text { IVF, } \\
\text { insem }\end{array}$ & sp & $\begin{array}{c}\text { IVF, } \\
\text { insem }\end{array}$ & Twice & Twin \\
\hline anti-TPO (52/71) & levothyroxine & 1 & & $1 / 1$ & - & - & - & - & - \\
\hline
\end{tabular}




\begin{tabular}{|c|c|c|c|c|c|c|c|c|c|}
\hline & levothyroxine + ASA & 1 & - & $1 / 1$ & - & - & - & - & - \\
\hline & ASA & 3 & $1 / 3$ & $1 / 3$ & $1 / 3$ & - & - & - & - \\
\hline & LMWH & 1 & - & $1 / 1$ & - & - & - & - & - \\
\hline & - & 3 & - & $3 / 3$ & - & - & - & - & 1 \\
\hline \multirow{2}{*}{ anti-TPO + ANA $(5 / 71)$} & prednisolone & 1 & - & $1 / 1$ & - & - & - & - & - \\
\hline & ASA + LMWH & 1 & - & $1 / 1$ & - & - & - & - & - \\
\hline $\begin{array}{c}\text { anti-TPO + ANA + anti-SS-A } \\
(1 / 71) \\
\end{array}$ & prednisolone & 2 & - & $1 / 1$ & $1 / 1$ & - & - & 1 & 1 \\
\hline anti-TPO + ANA + anti-Sm $(1 / 71)$ & prednisolone & 2 & $1 / 2$ & $1 / 1$ & - & - & - & 1 & - \\
\hline \multirow{2}{*}{ anti-TPO + anti-dsDNA $(3 / 71)$} & prednisolone & 1 & - & - & $1 / 1$ & - & - & - & - \\
\hline & ASA + prednisolone & 1 & - & $1 / 1$ & - & - & - & - & - \\
\hline \multirow{2}{*}{ anti-TPO + a-sperm $(2 / 71)$} & prednisolone & 1 & $1 / 1$ & - & - & - & - & - & - \\
\hline & ASA + LMWH & 1 & - & $1 / 1$ & - & - & - & - & - \\
\hline Summary & - & 19 & $3 / 19$ & $13 / 19$ & $3 / 19$ & - & - & 2 & 2 \\
\hline
\end{tabular}

Table XI: Pregnancies, deliveries and abortions among patients with autoimmune thyroiditis and euthyroidism along with antibodies of systemic autoimmune diseases and a-sperm (N: number of patients) 
When anti-TPO antibody was positive and the patients with euthyroidism, in the followup period 19 concepcions were verified: 3/19 ABs, 16/19 child-briths (13/16 sp developed pregnancies and 3/16 IVF/insem pregnancies). In addition 2 women were pregnant twice and 2 pregnancies resulted twins (Table XI).

Among such women, who with autoimmune thyroiditis (with latent hypothyroidism or euthyroidism) and aPLs and/or anti-tTG and/or a-sperm antibody, the types of treatment and obstetrical results are represented in other chapters of dissertation.

\title{
IV. CELIAC DISEASE IN RELATION TO REPRODUCTIVE FAILURES
}

\begin{abstract}
Aims
The anti-tTG antibody for CD was examined in female and male patients (they are partners of our female patients), then anti-tTG positive patients underwent deep duodenal biopsy for histological examination in order to confirm the diagnosis of CD and we carried laboratory tests out by them too.
\end{abstract}

\section{Results}

Among male patients 4/500 (0.8 \%) anti-tTG positivity has been demonstrated; histology was pathognomic for $\mathrm{CD}$ in all of them and the examination of sperm showed normal parameters in all cases (Table XII).

\begin{tabular}{|c|c|c|c|c|c|}
\hline & Partner's history & $\begin{array}{c}\text { anti-tTG } \\
\text { (U/ml) }\end{array}$ & $\begin{array}{c}\text { Associated } \\
\text { antibodies }\end{array}$ & $\begin{array}{c}\text { Deep duodenal } \\
\text { biopsy }\end{array}$ & $\begin{array}{c}\text { Sperm } \\
\text { findings }\end{array}$ \\
\hline 1 & 5 inseminations & 76.1 & aPS & total villous atrophy & physiological \\
\hline 2 & $\begin{array}{c}2 \text { ABs (W 8,8), } \\
\text { 1 IVF }\end{array}$ & 104.0 & aPS & total villous atrophy & physiological \\
\hline 3 & 2 IVFs & 467.0 & - & subtotal villous atrophy & physiological \\
\hline 4 & $\begin{array}{c}\text { 2 children } \\
\text { previous partner), } \\
\text { 2 IVFs }\end{array}$ & 114.0 & - & total villous atrophy & physiological \\
\hline
\end{tabular}

Table XII: Anti-tTG antibody positivity among male patients

(IVF: in vitro fertilization) 
Among the women we could detect anti-tTG in 11/500 (2.2\%) cases of whom the diagnosis of celiac disease was histologically confirmed in 8/500 (1.6\%) patients (Table XIII).

Treatment in the follow-up period:

In the follow-up period success of gluten-free diet we could verify $3 / 8$ miscarriages, $3 / 8$ child-births (2/3 sp developed pregnancies and $1 / 3 \mathrm{IVF} /$ insem pregnancies) and 2/8 pregnancies are currently in progress (Table XIII).

\section{Case reports}

\section{Case 1}

In May 2009 we examined the 30-year-old female patient after 5 unsuccessful inseminations. Her medical history included treatment for bronchial asthma in childhood and permanent constipation. Her laboratory findings (Hgb: $134 \mathrm{~g} / \mathrm{l} ; \mathrm{Htc}: 0.41$ 1/1; serum Fe: $7.4 \mu \mathrm{mol} / \mathrm{l}$; serum ferritin: $28.7 \mathrm{ng} / \mathrm{ml}$; serum vitamin B12: $344 \mathrm{pg} / \mathrm{ml}$; serum folic acid: $20 \mathrm{ng} / \mathrm{ml}$; serum total protein: $69 \mathrm{~g} / \mathrm{l}$; serum albumin: $45 \mathrm{~g} / \mathrm{l}$ ) showed slight iron deficiency and selective IgA deficiency (serum IgA: $0.67 \mathrm{~g} / \mathrm{l}$; serum IgG: $10.89 \mathrm{~g} / \mathrm{l}$; serum IgM: $0.84 \mathrm{~g} / \mathrm{l})$. The immuno-serological tests demonstrated the positivity of anti-tTG $(23 \mathrm{U} / \mathrm{ml})$ and aCL (it could be detected only on one occasion, it turned to negative already after 6 weeks). Based on the subtotal villous atrophy confirmed by histological examination, we diagnosed $\mathrm{CD}$ at which we recommended further observation for selective IgA deficiency and APS. The patient kept a strict gluten-free diet and received also ASA (100 mg/day orally) therapy (Table XII).

\section{Case 2}

The 34-year-old male patient, examined in May 2009, had no complaints. However, his laboratory findings (Hgb: $143 \mathrm{~g} / \mathrm{l}$; Htc: 0.44 1/1; serum Fe: 4.9 mmol/1; serum ferritin: 3.4 $\mathrm{ng} / \mathrm{ml}$; serum vitamin B12: $389 \mathrm{pg} / \mathrm{ml}$; serum folic acid: $2.86 \mathrm{ng} / \mathrm{ml}$; serum total protein: $63 \mathrm{~g} / \mathrm{l}$; serum albumin: $41 \mathrm{~g} / \mathrm{l}$ ) indicated iron and folic acid deficiency and slight hypoproteinemia. Of his immuno-serological results, anti-tTG $(76.1 \mathrm{U} / \mathrm{ml})$ has proven to be positive and the aPS showed positivity on one occasion. 


\begin{tabular}{|c|c|c|c|c|c|c|c|c|}
\hline & st/if & History & $\begin{array}{c}\text { anti-tTG } \\
(\mathrm{U} / \mathrm{ml})\end{array}$ & $\begin{array}{l}\text { Associated } \\
\text { antibodies }\end{array}$ & $\begin{array}{c}\text { Deep duodenal } \\
\text { biopsy }\end{array}$ & Diagnosis & Therapy & $\begin{array}{c}\text { Pregnancy, } \\
\text { delivery, abortion }\end{array}$ \\
\hline 1 & st & 4 IVFs & 46.6 & a-sperm & $\begin{array}{l}\text { delayed due to the } \\
\text { patient's spontaneously } \\
\text { developed pregnancy }\end{array}$ & $\mathrm{CD}$ & ASA + gluten-free diet & $\begin{array}{c}1 \text { delivery } \\
\text { (spontaneous pregnancy) }\end{array}$ \\
\hline 2 & if & 1 delivery, 2 ABs (W 8,8) & 14.2 & anti-TPO, aPS & total villous atrophy & $\begin{array}{c}\text { CD, APS, } \\
\text { autoimmune thyroiditis }\end{array}$ & $\begin{array}{l}\text { ASA + gluten-free diet } \\
+ \text { levothyroxine }\end{array}$ & \\
\hline 3 & st & 5 inseminations & 23.0 & aCL, aPS & subtotal villous atrophy & $\begin{array}{c}\mathrm{CD}, \mathrm{APS} \\
\text { selective IgA deficiency }\end{array}$ & $\mathrm{ASA}+$ gluten-free diet & $\begin{array}{c}1 \text { IVF } \\
1 \text { delivery } \\
\text { (spontaneous pregnancy) }\end{array}$ \\
\hline 4 & if & 1 delivery, 1 AB (W 18) & 53.6 & - & negative & - & - & \\
\hline 5 & if & $\begin{array}{c}6 \text { inseminations, } \\
3 \mathrm{IVF}(2 \mathrm{ABs}, \mathrm{W} 8,18)\end{array}$ & 57.9 & - & negative & - & - & \\
\hline 6 & if & $\begin{array}{c}1 \text { procured } A B, \\
1 \mathrm{AB}(\mathrm{W} 6)\end{array}$ & 33.8 & aPS, aANX & negative & APS & ASA & \\
\hline 7 & st & 1 insemination & 28.6 & ANA & subtotal villous atrophy & $\begin{array}{c}\mathrm{CD}, \text { latent } \\
\text { hypothyroidism }\end{array}$ & $\begin{array}{l}\text { ASA + gluten-free diet } \\
+ \text { levothyroxine }\end{array}$ & $\begin{array}{l}1 \text { delivery (insemination), } \\
1 \text { spontaneous pregnancy }\end{array}$ \\
\hline 8 & if & $3 \mathrm{ABs}(\mathrm{W} 8,6,6)$ & 165.0 & $\begin{array}{l}\text { ANA, anti-Sm, } \\
\text { anti-TPO, } \\
\text { aANX }\end{array}$ & subtotal villous atrophy & $\begin{array}{c}\mathrm{CD}, \mathrm{APS}, \\
\text { autoimmune thyroiditis }\end{array}$ & $\begin{array}{l}\text { ASA + LMWH } \\
+ \text { gluten-free diet }\end{array}$ & 2 ABs $(W 9,5)$ \\
\hline 9 & if & $\begin{array}{c}1 \text { premature birth (W 29), } \\
4 \mathrm{ABs}(\mathrm{W} 23,21,10,5)\end{array}$ & 427.0 & - & total villous atrophy & $\begin{array}{l}\mathrm{CD}, \text { Leiden mutation } \\
\text { (heterozygous) }\end{array}$ & $\begin{array}{c}\text { ASA + LMWH } \\
+ \text { gluten-free diet }\end{array}$ & \\
\hline 10 & st & 3 IVFs & 11.3 & anti-TPO & subtotal villous atrophy & $\begin{array}{c}\mathrm{CD}, \\
\text { autoimmune thyroiditis }\end{array}$ & gluten-free diet & 1 spontaneous pregnancy \\
\hline 11 & if & 2 ABs (W 5,5) & 19.4 & $\begin{array}{l}\text { anti-SS-A, } \\
\text { anti-SS-B }\end{array}$ & subtotal villous atrophy & $\mathrm{CD}$ & $\mathrm{ASA}+$ gluten-free diet & $1 \mathrm{AB}(\mathrm{W} 8)$ \\
\hline
\end{tabular}

Table XIV: Anti-tTG antibody positivity among female patients (AB: abortion, IVF: in vitro fertilization, W: week) 
Histological examination demonstrated total villous atrophy. The findings related to the sperm of this male patient with CD showed normal values concerning all examined parameters including the number, shape and motion of his sperm cells. The patient started gluten-free diet (Table XIII).

Curiously, the partner of the above male patient with CD was a female patient with $\mathrm{CD}$, APS, and selective IgA deficiency, also diagnosed by us (Table XII, XIII)). Their genetic testing detected HLA-DQ2 homozygous state in both of them. The couple with gluten sensitivity commonly continued keeping a strict gluten-free diet. In November 2009 - as no spontaneous conception occurred up to that time - she underwent IVF which ended with no success.

In March 2010 another IVF was planned, however the menstruation of the female patient delayed and her pregnancy test indicated spontaneously conceived gravidity. The pregnant woman with CD underwent regular medical and gynecologic follow-ups and no overt state of deficiency (iron, vitamin B12, folic acid) could be detected during her pregnancy. In October 2010, in the $26^{\text {th }}$ week of her pregnancy her anti-tTG has already proven to be negative $(0.52 \mathrm{U} / \mathrm{ml})$. In January 2011 she delivered a healthy newborn (birth weight: $2980 \mathrm{~g}$ ) in the $38^{\text {th }}$ week of her gestation.

\section{ANTI-SPEM ANTIBODY IN RELATION TO REPRODUCTIVE FAILURES}

\section{Aims}

The aim was to establish the prevalence of a-sperm antibody in female patient with reproductive failures.

\section{Results}

The a-sperm antibody could be presentable in 49/500 (9.8\%) cases and it could be detect alone in 21/49 women. In further 28/49 patients a-sperm was concomitant with other antibodies such as (Figure 14):

- a-sperm + ANA: $3 / 28$ patients

- a-sperm + ANA + aCL (+/-): 2/28 patients

- a-sperm + ANA + anti-TPO: 1/28 patient

- a-sperm + ANA + anti-dsDNA + anti-TPO: 1/28 patient 
- a-sperm + ANA + anti-SS-B + anti-TPO: 1/28 patient

- a-sperm + aCL (+/+): 2/28 patients

- a-sperm + aCL (+/-): 2/28 patients

- a-sperm + aCL (+/-) + aPT: 1/28 patient

- a-sperm + aCL (+/+) + aPS: 2/28 patients

- a-sperm + aCL (+/-) + aANX: 1/28 patient

- a-sperm + aPS: $2 / 28$ patients

- a-sperm + aANX: 1/28 patient

- a-sperm + aPS + aANX: 1/28 patient

- a-sperm + anti-dsDNA + aCL (+/+): 1/28 patient

- a-sperm + anti-dsDNA + aCL (+/-): 1/28 patient

- a-sperm + anti-dsDNA + anti-tTG: $1 / 28$ patient

- a-sperm + anti-SS-A: 2/28 patients

- a-sperm + anti-Sm: 1/28 patient

- a-sperm + anti-TPO: $2 / 28$ patients
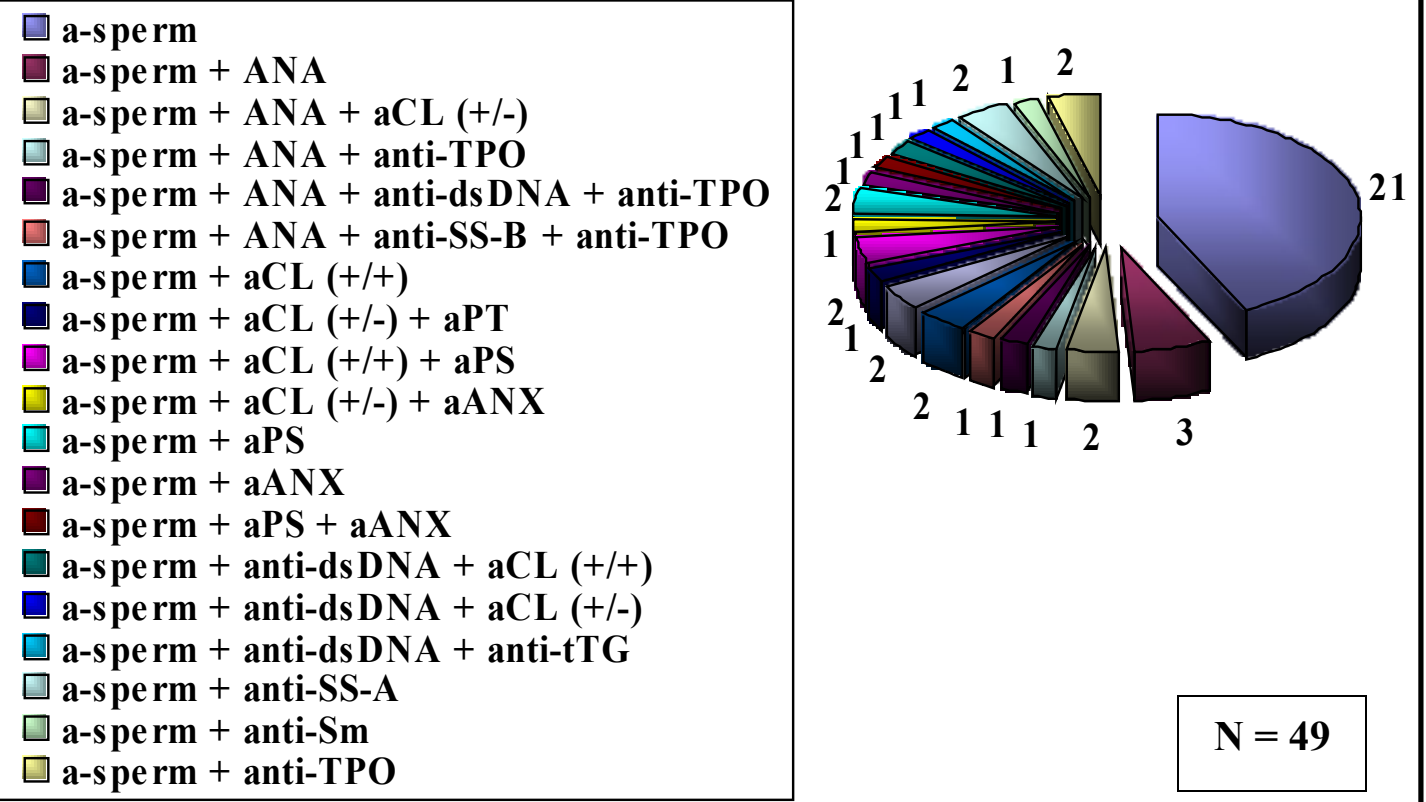

Figure 14: Patients with a-sperm antibody (N: number of patients) 
Treatment in the follow-up period:

When the patient was a-sperm positive alone or with ANA or anti-SS-A antibody, there were 19 conceptions such as: 2/19 ABs, 16/19 deliveries (13/16 sp developed pregnancies, 3/16 IVF/insem pregnancies) and 1/19 pregnancy is currently in progress furthermore we verified 1 twice-pregnant woman and 3 pregnancies resulted twins (Table XIV).

Among such women, who had got not only a-sperm and antibodies of autoimmune diseases but also aPLs, anti-TPO and/or anti-tTG, the types of treatment and obstetrical results are represented in other chapters of dissertation. 


\begin{tabular}{|c|c|c|c|c|c|c|c|c|c|}
\hline \multirow[b]{2}{*}{ Patients (N) } & \multirow[b]{2}{*}{ Therapy } & \multirow[b]{2}{*}{$\begin{array}{c}\text { Conception } \\
\text { (all) }\end{array}$} & \multirow[b]{2}{*}{ Abortion } & \multicolumn{2}{|c|}{ Delivery } & \multicolumn{2}{|c|}{ Pregnancy } & \multicolumn{2}{|c|}{ Pregnancy/Delivery } \\
\hline & & & & sp & $\begin{array}{c}\text { IVF, } \\
\text { insem }\end{array}$ & sp & $\begin{array}{c}\text { IVF, } \\
\text { insem }\end{array}$ & Twice & Twin \\
\hline \multirow{4}{*}{ a-sperm $(21 / 49)$} & prednisolone & 12 & - & $9 / 12$ & $2 / 12$ & $1 / 12$ & - & 1 & 2 \\
\hline & prednisolone + ASA & 1 & - & $1 / 1$ & - & - & - & - & - \\
\hline & ASA & 1 & $1 / 1$ & - & - & - & - & - & - \\
\hline & ASA + LMWH & 1 & - & $1 / 1$ & - & - & - & - & - \\
\hline a-sperm + ANA (3/49) & prednisolone & 3 & - & $2 / 3$ & $1 / 3$ & - & - & - & 1 \\
\hline a-sperm + anti-SS-A (2/49) & prednisolone & 1 & $1 / 1$ & - & - & - & - & - & - \\
\hline Summary & - & 19 & $2 / 19$ & $13 / 19$ & $3 / 19$ & $1 / 19$ & - & 1 & 3 \\
\hline
\end{tabular}

Table XIV: Pregnancies, deliveries and abortions among patients with a-sperm antibody alone and a-sperm with antibodies of systemic autoimmune diseases (N: number of patients) 


\section{DISCUSSION OF THE DISSERTATION}

Of couples in reproductive age, 8 to $10 \%$ are sterile and 15 to $20 \%$ are infertile. A couple is sterile when no pregnancy occurs within 2 years. In case of infertility, conception takes place; however due to any case, no live neonate is born from the pregnancy/pregnancies. 1 to $2 \%$ of women in childbearing age have habitual abortions, or at least 3 consecutive spontaneous miscarriages. Underlying both sterility and infertility, there may be various genetic, hormonal, gynecologic, andrologic or immunologic factors; however no detectable cause is found in a significant part of cases. (Auto)antibodies may be present in both members of the couples, causing failure of attempts to have children. Often these are not recognized, as the affected individuals have no signs or symptoms suggesting any autoimmune disease. Nevertheless, sterility/infertility in women of childbearing age who have autoantibodies is considered as a potential sign of an autoimmune disease.

Due to the importance of the issue, we believed that studying of the immunologic processes underlying sterility and infertility is worth to be the topic of a $\mathrm{PhD}$ thesis.

\section{Antiphospholipid antibodies and antiphospholipid syndrome in relation to reproductive failures}

In our work with sterile/infertile women, we studied not only the presence of aCL and aß2GPI antibodies which are included in the diagnostic criteria of APS, but also the presence of further aPLs (aANX, aPS, and aPT) which are not among the criteria, but can often be found in the background of pathologic pregnancies.

Antibodies included in the laboratory criteria of APS (aCL, aß2GPI):

The aCL antibody could be detected on two occasions in 27/500 (5.0 \%) (st./if.: 4/23) patients; in addition to aCL further aPLs were also present in 11/27 of them. The aCL antibody could be observed on one occasion in 34/500 (6.8 \%) (st./if.: 17/17) female patients; in this group other aPLs were found in addition to aCL in 17/34 patients. The presence of aß2GPI antibodies could be demonstrated in 15/500 (3.0\%) (st./if.: 4/11) patients (in 9/15 aCL-positive and in 6/15 aCL-negative women): aß2GPI proved to be positive once or twice in $10 / 15$ and $5 / 15$ patients respectively. 
The following aPLs were observed among the aCL-negative patients:

Less frequent aPLs detected in 76/439 (17.3\%) of the 439/500 aCL-negative female patients: 3 aß2GPI; 45 aPS; 1 aPS + aß2GPI; 1 aPS + aPT; 6 aPS + aANX; 1 aPT; 1 aPT + aß2GPI; 16 aANX; 1 aANX + aß2GPI; 1 aPS + aPT + aANX.

We found aPL in a total of 137/500 women during the study; while taking both clinical and laboratory criteria of APS into consideration, the diagnosis of APS could be established in 11/500 (2.2\%) patients, including 5/11 and 6/11 patients with PAPS and SAPS respectively.

However, we used anticoagulant therapy during the follow-up period not only in patients with confirmed APS, but also in those who did not fulfill the diagnostic criteria of the disease completely. Consequently, 22 pregnancies (2/22 ABs, 19/22 deliveries; $1 / 22$ pregnancy is currently in progress) occurred in patients with aCL positivity on two occasions, and there were 15 pregnancies (3/15 ABs, 12/15 childbirths) in women who were aCL-positive on one occasion. In the group of aCL antibody-negative women who were at the same time carriers of one of the less frequent aPLs, a total of 52 conceptions occurred (13/52 ABs, 32/52 deliveries; 7/52 pregnancies are currently in progress). Finally, among aCL-negative women who were at the same time carriers of multiple less frequent sPLs, 8 pregnancies were observed (1/8 AB, $6 / 8$ childbirths, $1 / 8$ pregnancy is currently in progress). Having taken the successfully delivered pregnancies into consideration, we also demonstrated that ASA + LMWH therapy has proven to be the most effective treatment in patients with aPLs.

Summing up, it can be stated that the previously undetected APS may be an important etiologic factor underlying sterility/infertility; furthermore an appropriate therapy can terminate the adverse effects of aPLs that cause morbidities of pregnancy $(92,93,94)$.

\section{Antibodies of the systemic autoimmune diseases in relation to reproductive failures}

In addition to APS, we also looked in our female patients for other autoantibodies (ANA, anti-dsDNA, anti-Jo-1, anti-Sm, anti-RNP, anti-SS-A, anti-SS-B) suggesting the presence of other systemic autoimmune diseases. 
The presence of autoantibodies was observed in a total of 151/500 (30.2\%) patients; these antibodies occurred as single in 66/151 patients, and in the remaining 85/151 cases they were detected in association with aPLs and/or with antibodies of organspecific autoimmune diseases (anti-tTG, anti-TPO).

In this group of patients we used not only immunosuppressive prednisolone therapy, but also anticoagulant therapy in several cases, due to which 29 conceptions occurred (5/29 ABs, 22/29 childbirths; 2/29 pregnancies are currently in progress).

The results of our study showing that ANA, anti-dsDNA and anti-SS-A antibodies, particularly together with aPLs, occur very frequently in patients with reproductive problems are in accordance with the international literature. Although we could not diagnose any systemic autoimmune disease among our patients, as the specific clinical signs and symptoms characteristic to those were not present, nevertheless anticoagulant therapy seems to be justified in the presence of autoantibodies, as this may make a successful childbirth possible $(92,93,94)$

\section{Autoimmune thyroiditis and thyroid dysfunction in relation to reproductive failures}

We screened the women with reproductive failure also for thyroiditis and thyroid dysfunction.

Autoimmune thyroiditis:

Anti-TPO antibodies were found in a total of 71/500 (14.2\%) patients, including 52/71 euthyroid women and 19/71 patients with latent hypothyroidism. Among the 9/19 women with latent hypothyroidism, 9/19 had only anti-TPO, while in 10/19 other antibodies were also present in addition to the anti-TPO. In the group of euthyroid patients anti-TPO positivity alone occurred in 18/52, while aPLs, antibodies of systemic autoimmune diseases, anti-tTG and a-sperm antibodies could also be detected in 34/52 patients.

Thyroid dysfunction without autoimmune thyroiditis:

Among our patients, 18/500 (3.6\%) women had latent hypothyroidism without being a carrier of anti-TPO antibodies. Furthermore, no autoantibody at all could be found in 9/18 patients; in the other 9/18 patients ANA, anti-dsDNA, aPLs (aCL, aPS), anti-tTG and a-sperm antibodies could be observed in addition to the latent hypothyroidism. 
Patients with latent hypothyroidism received levothyroxine substitution during the follow-up period; checks of TSH levels were performed in the euthyroid anti-TPOpositive women. Among the women with autoimmune thyroiditis, 14 pregnancies were observed (4/14 $\mathrm{ABs}, 8 / 14$ childbirths; $2 / 14$ pregnancies are currently in progress). In the anti-TPO-positive euthyroid women a total of 19 conceptions (3/19 ABs, 16/19 childbirths) occurred. A total of 5 childbirths occurred among patients who had no detectable anti-TPO or any other antibodies in association with their thyroid dysfunction.

Our results demonstrate that levothyroxine substitution should start already prior to conception in patients with latent or overt hypothyroidism and it should be continued, with close monitoring of TSH levels during pregnancy. As sterility/infertility may also be caused by autoimmune thyroiditis in a euthyroid patient, regular checking of TSH in TPO-positive women of reproductive age should be underlined; in these cases the upper limit of TSH is $2.5 \mathrm{U} / \mathrm{L}(93,94)$.

\section{Celiac disease in relation to reproductive failures}

Determination of anti-tTG, required for the detection of CD was performed not only in our female patients but in their male partners as well, and then deep duodenal biopsy and laboratory tests seeking malabsorption were also done in the anti-tTG positive patients.

Among men, anti-tTG positivity was observed in 4/500 (0.8\%) patients, and the histological examination confirmed $\mathrm{CD}$ in all of them. Among women, anti-tTG positivity was detected in 11/500 (2.2\%), and the diagnosis of CD could be confirmed by histological examination in 8/500 (1.6\%) of them. As a result of a strict gluten-free diet, 8 pregnancies (3/8 ABs, $3 / 8$ childbirths, $2 / 8$ pregnancies are currently in progress) developed during the follow-up. No premature birth and no IUGR of the newborn babies occurred among the mothers with $\mathrm{CD}$.

A curiosity of our study: we could demonstrate previously unrecognized CD in both members of a couple, and then at a gluten-free diet they had, via spontaneous 
conception a healthy offspring in $2011(95,96)$. At a gluten-free diet, no positivity was shown in the child by periodic anti-tTG tests. With the examination of blood and tissue (umbilical cord and placenta) samples obtained from parents and child, we could make a contribution to an international genetic study of non-HLA genes underlying CD.

\section{Anti-sperm antibody in relation to reproductive failures}

In our female patients, we also performed the examination of a-sperm antibodies which may be an emerging underlying etiologic factor of reproductive failure.

A-sperm could be detected in 49/500 (9.8\%) patients, of them no other antibody was present in 21/49, while in the further $28 / 49$ women also autoantibodies could be observed in addition to a-sperm.

In a-sperm positive patients, with the use of prednisolone, and added anticoagulant therapy in some cases, 19 conceptions (2/19 ABs, 16/19 deliveries, 1/19 pregnancy is currently in progress) occurred.

Although a-sperm is a hetero-antibody in women, nevertheless the results of our study confirmed that it is frequently associated with autoantibodies (it has been observed mostly with ANA, anti-dsDNA, anti-TPO, and aPLs); therefore immunosuppressive therapy may be justified in patients with sterility/infertility (94).

In summary, it can be stated: the results of our series of examinations shed light on the fact that it is worthwhile to examine sterile/infertile couples for autoimmune diseases, autoantibodies, as the confirmation and appropriate treatment of these may lead to a successful childbirth. The results of our $\mathrm{PhD}$ work have been published in both Hungarian and international literature $(92,93,94,95,96)$, and successful conception of 155 children occurred during our treatments. As far as we know, we published on this topic as first in Hungary. 


\section{NEW OBSERVATION}

1. As first in Hungary, we introduced an organized assessment of infertile couples for autoimmune diseases in an outpatient basis within the frame of specialist clinics of immunology.

2. Our outpatient clinics of this purpose attained not only a regional but also a trans-border role in a short time. The number of patients with reproductive failure examined and treated by us has reached, and currently exceeded 500. In addition to infertile couples from Zala County, a significant part of our patients arrived from Budapest, from all Trans-Danubian counties, on several occasions from even farther areas of the country (Csongrád, Bács-Kiskun, Hajdú-Bihar counties), moreover from abroad (Austria, Slovakia, Romania) as well.

3. During our activity we could establish a very good and successful professional relationship with the representatives of the partner specialties (Clinical Genetics, Obstetrics-Gynecology, Endocrinology, Gastroenterology, Laboratory Diagnostics), and we formed an interdisciplinary working group.

4. Our results obtained in relation to APS illuminate the necessity of an assessment of infertile women not only in pathological states which fulfill the diagnostic criteria of APS, but it is justified on the one hand already earlier (after one or two abortions in the first trimester, or also related to infertility), on the other hand in the presence of other pathological states which are not included to the criteria (e.g. history of preeclampsia, premature delivery, low-weight newborn).

5. Our findings demonstrate that antibodies not included to the laboratory criteria of APS (aPS, aANX) have a significant relevance in the development of pregnancy-related morbidities, so that in the presence of these an appropriate anticoagulant therapy may result in childbirth.

6. Although the infertile women had no clinical symptoms suggesting autoimmune diseases (no systemic autoimmune disease, except APS, could be diagnosed); nevertheless their chances for childbirth were improved by low-dose corticosteroid therapy, administered - often in association with anticoagulation due to their auto-antibody positivity.

7. Thyroid diseases occurred frequently among our patients; therefore we strongly recommend screening for autoimmune thyroiditis and thyroid dysfunction in women with reproductive failure. 
8. By presenting the case of a couple with celiac disease, which is considered a rarity in Hungary, we wish to call attention to the fact that celiac disease in both women and men may be the underlying cause of pathological states of pregnancy, so that a screening of both members of the infertile couples is justified. Engaged in an international scientific research, with samples obtained from the parents and their offspring (sera and tissues taken from the placenta and the umbilical cord in relation to the delivery), we could made a contribution to a more exact elucidation of the genetic background of celiac disease.

9. Our study exemplifies well that anti-sperm antibodies appear often in association with other auto-antibodies, so that an administered anticoagulation and/or corticosteroid therapy may prove to be effective in this group of patients.

10. Our results support the fact that immunological assessment should be a part of the assessment of infertile couples, in addition the treatment and care of couples with demonstrated antibody positivity requires a multidisciplinary cooperation of the representatives of partner specialties in order to attain a successful childbirth.

The attachment bellow includes the tableau portraits of a part of the children successfully delivered as a result of our research and therapy. 


\section{ACKNOWLEDGMENTS}

These studies were carried out at the University of Szeged, Faculty of Medicine and Zala County Hospital, Department of Internal Medicine, Zalaegerszeg.

I am grateful for the help of my project leader, Prof. Bártfai György MD, PhD and my supervisor Med. Habil. Beáta Gasztonyi $M D, P h D$, who managed my studies and provided support and useful advice throughout my work.

I express my thanks to my first teacher János Hafner MD too.

I am also thankful to my collegues Marianna Hartwig MD, Marianna Tihanyi MD (Genetics Laboratory, Zala County Hospital), Magdolna Aleksza PhD (University of Western Hungary, Szombathely), Tatjana Nagy MD (Central Laboratory, Zala County Hospital) and all specialists of Obstetrics and Gynaecology of Zala County Hospital and other hospitals, moreover my assistants Erzsébet Kereszturi Horváthné, Piroska Kiss Horváthné, Judit Bicsák Halászné for assisting in the clinical aspects of the studies and thanks to all staff members of the Department of Internal Medicine of Zala County Hospital for their assistance during procedures and data collection.

I express my gratitude and thanks to my Mother and Brother for their encouraging support during all my studies and research work. 


\section{ÖSSZEFOGLALÁS}

A fogamzóképes párok 8-10\%-a steril, 15-20\%-a pedig infertilis. Steril a pár, ha két éven belül nem következik be graviditás. Infertilitás esetén a fogantatás megtörténik, azonban a terhesség(ek)böl valamilyen ok miatt mégsem születik élő újszülött. A reproduktív korú nők 1-2 \%-a habituális vetélő, vagyis legalább 3 spontán vetélés követi egymást. Mind a sterilitás, mind pedig az infertilitás hátterében különböző genetikai, hormonális, nőgyógyászati, andrológiai, immunológiai tényezők állhatnak, azonban az esetek jelentős részében nincs kimutatható ok. Sikertelen gyermekvállalást okozva a párok mindkét tagjánál (auto)antitestek lehetnek jelen. Ezek gyakran nem kerülnek felismerésre, hiszen az érintetteknek autoimmun betegségre utaló tünete nincsenek. Ugyanakkor a reproduktív korban lévő nőknél a sterilitást/infertilitást - autoantitestek jelenlétében - autoimmun kórképek lehetséges tüneteként értékeljük.

A téma fontossága miatt éreztük úgy, hogy a sterilitás, infertilitás hátterében álló immunológiai folyamatok vizsgálata $\mathrm{PhD}$ dolgozat témájaként szolgálhat.

(A magyar nyelvü összefoglalóban használatos rövidítések az angol nyelvű $\mathrm{PhD}$ dolgozat rövidítések jegyzékében találhatókkal egyezőek.)

\section{Antifoszfolipid antitestek és antifoszfolipid szindróma a reproduktív elégtelenségek hátterében}

Munkánk során steril/infertilis nők körében vizsgáltuk nemcsak az APS diagnosztikus kritériumában foglalt aCL és aß2GPI antitestek, hanem a kritériumok között nem szereplő, a terhességi kórállapotok hátterében viszont gyakran fellelhető további aPL-ek (aANX, aPS, and aPT) jelenlétét.

Az APS laboratóriumi kritériumai között szereplö antitestek (aCL, aß2GPI):

Az aCL-antitest két alkalommal 27/500 (5,0 \%) (st/if: 4/23) betegnél volt kimutatható, közöttük 11/27 esetben az aCL mellett további aPL-ek is jelen voltak. Az aCL-antitest egyszer volt észlelhető 34/500 (6,8 \%) (st/if: 17/17) nőbetegnél, ebben a csoportban 17/34 esetben találtunk az aCL mellett más aPL-eket is. Az aß2GPI antitestet 15/500 (3,0 \%) (st/if: 4/11) nőnél tudtuk igazolni (9/15 aCL-pozitív és 6/15 aCL-negatív nőnél): 10/15 betegnél egyszer, 5/15 betegnél pedig kétszer bizonyult az aß2GPI pozitívnak. Az aCL-negatív betegeknél észlelt aPL-ek: 
A 439/500 aCL-negatív nöbeteg között 76/439 (17,3 \%) esetben tudtunk kimutatni ritkább aPL-t: 3 aß2GPI, 45 aPS, 1 aPS + aß2GPI, 1 aPS + aPT, 6 aPS + aANX, 1 aPT, $1 \mathrm{aPT}+\mathrm{a} 2 \mathrm{GPI}, 16 \mathrm{aANX}, 1 \mathrm{aANX}+\mathrm{a} 2 \mathrm{GPI}, 1 \mathrm{aPS}+\mathrm{aPT}+\mathrm{aANX}$.

Vizsgálatunk során összesen 137/500 nőnél találtunk aPL-t, közöttük - az APS klinikai és laboratóriumi kritériumait is figyelembe véve - 11/500 (2,2\%) betegnél tudtuk kimondani az APS diagnózisát: 5/11 PAPS és 6/11 SAPS került leírásra.

A követési időszakban azonban nemcsak az igazolt APS-ás betegeknél, hanem a kórkép diagnosztikus kritériumait maradéktalanul nem teljesítők körében is alkalmaztuk az antikoaguláns kezelést. Így a két alkalommal aCL-pozitív betegeknél 22 terhesség (2/22 AB, 19/22 szülés, 1/22 jelenleg is zajló terhesség), az egy alkalommal aCL-pozitív nőknél pedig 15 terhesség (3/15 AB, 12/15 szülés) jött létre. Az aCL-antitest negatív, azonban egy-egy ritkább aPL-t hordozó nők csoportjában összesen 52 fogantatás történt (13/52 AB, 32/52 szülés, 7/52 jelenleg is zajló terhesség). Végezetül az aCL-negatív, de egyidejüleg több ritka aPL-t hordozóknál 8 terhességet észleltünk ( $1 / 8 \mathrm{AB}, 6 / 8$ szülés, $1 / 8$ jelenleg is zajló terhesség). A sikeresen kihordott terhességeket figyelembe véve mi is igazoltuk, hogy aPL-ek jelenlétekor az ASA + LMWH kezelés bizonyul a legeffektívebbnek.

Összegzésként elmondhatjuk, hogy sterilitás/infertilitás hátterében fontos kóroki tényező lehet az addig fel nem fedezett APS, továbbá megfelelő kezeléssel a terhességi morbiditásokat előidéző aPL-ek káros hatásai megszüntethetőek.

\section{Szisztémás autoimmun kórképekre jellemző auto-antitestek a reproduktív elégtelenségek hátterében}

Nőbetegeinknél az APS-en kívül, más szisztémás autoimmun betegségekre utaló autoantitesteket (ANA, anti-dsDNA, anti-Jo-1, anti-Sm, anti-RNP, anti-SS-A, anti-SS-B) is kerestünk.

Összesen 151/500 (30,2 \%) betegnél észleltük auto-antitestek jelenlétét: 66/151 esetben ezek az antitestek önmagukban, a fennmaradó 85/151 esetben aPL-ekkel és/vagy szervspecifikus autoimmun betegségek auto-antitestjeivel (anti-tTG, anti-TPO) együtt tudtuk kimutatni. 
Ebben a betegcsoportban nemcsak immunszupresszív prednisolon kezelést folytattunk, hanem több esetben antikoaguláns kezelést is, melyeknek köszönhetöen 29 fogantatás (5/29 AB, 22/29 szülés, 2/29 jelenleg is zajló terhesség) következett be.

Vizsgálatunk eredményei - melyek szerint reprodukciós problémával küzdők körében az ANA, az anti-dsDNA és az anti-SS-A antitestek elöfordulása különösen aPL-ek mellett nagyon gyakori - a szakirodalommal egybehangzóak. Betegeinknél szisztémás autoimmun betegséget diagnosztizálni nem tudtunk, hiszen az ezekre specifikus klinikai tünetek valamennyiüknél hiányoztak, azonban auto-antitestek jelenlétében az immunszupresszív kezelésnek létjogosultsága van, hiszen ezzel a sikeres gyermekvállalás lehetővé válik.

\section{Autoimmun thyreoiditis és pajzsmirigy diszfunkció a reproduktív elégtelenségek hátterében}

A reproduktív elégtelenségben szenvedő nőket autoimmun thyreoiditis és pajzsmirigy diszfunkció irányában is vizsgáltuk.

Autoimmun thyreoiditis:

Munkánk során anti-TPO antitestet összesen 71/500 (14,2 \%) betegnél találtunk, közülük 52/71 nő euthyreoid volt, 19/71 betegnél latens hypothyreosis volt igazolható. A latens hypothyreosisban szenvedök között 9/19 nönél csak anti-TPO volt jelen, további 10/19 esetben anti-TPO mellett más antitestek is észlelhetőek voltak. Az euthyreoid betegek csoportjában 18/52 anti-TPO-pozitivitás fordult elő önmagában, 34/52 betegnél az anti-TPO mellett aPL-ek, szisztémás autoimmun betegségek antitestjei, anti-tTG és a-sperm is kimutatható volt.

Pajzsmirigy diszfunkció autoimmun thyreoiditis nélkül:

Beteganyagunkban 18/500 (3,6 \%) nő szenvedett latens hypothyreosisban anélkül, hogy anti-TPO antitestet hordozott volna. Söt 9/18 betegnél egyáltalán nem találtunk semmilyen auto-antitestet, további 9/18 esetben a latens hypothyreosis mellett ANA, anti-dsDNA, aPL-ek (aCL, aPS), anti-tTG és a-sperm antitest észlelhető volt.

A követési időszakban latens hypothyreosisban szenvedő betegeinknél levothyroxin szubsztitúciót végeztünk, euthyreoid anti-TPO-pozitív nőknél TSH-ellenőrzést 
folytattunk. Autoimmun thyreoiditisben szenvedő nők között 14 terhességet (4/14 AB, 8/14 szülés, 2/14 jelenleg is zajló terhesség) észleltünk. Az anti-TPO-pozitív euthyreoid nőknél összesen 19 fogantatás (3/19 AB, 16/19 szülés) történt. Azoknál a betegeinknél, akiknél a pajzsmirigy diszfunkció mellett sem anti-TPO, sem más antitest nem volt kimutatható, összesen 5 szülés következett be.

Eredményeink bizonyítják, hogy latens vagy manifeszt hypothyreosis esetén a levothyroxin pótlást már a fogantatást megelözően el kell kezdeni és a terhesség alatt szoros TSH ellenőrzés mellett folytatni kell. Euthyreosissal járó autoimmun thyreoiditis is lehet oka sterilitásnak/infertilitásnak, így a reproduktív életkorban levő anti-TPOpozitív nők rendszeres TSH-kontrollja fontos, ezekben az esetekben a TSH felső határa $2,5 \mathrm{U} / \mathrm{L}$.

\section{Lisztérzékenység a reproduktív elégtelenségek hátterében}

A CD igazolásához szükséges anti-tTG meghatározást nemcsak nőbetegeinknél, hanem férfi partnereiknél is elvégeztük, majd az anti-tTG-pozitív betegeknél mély duodenum biopszia és felszívódási zavar irányában laboratóriumi vizsgálatok is történtek.

A férfiaknál 4/500 (0,8 \%) esetben észleltük az anti-tTG pozitivitását, a szövettani lelet mindegyiküknél kórjelző volt CD-re. A nőknél 11/500 (2,2 \%) anti-tTG-pozitivitás volt kimutatható, közülük 8/500 (1,6 \%) betegnél tudtuk a CD diagnózisát szövettani lelettel is alátámasztani. A követési időszakban szigorú gluténmentes diéta eredményeként 8 terhesség alakul ki (3/8 AB, 3/8 szülés, 2/8 jelenleg is zajló terhesség); a CD-s anyáknál koraszülés, újszülöttjeiknél IUGR nem fordult elö.

Vizsgálatunk kuriózumát adja, hogy egy pár mindkét tagjánál tudtuk igazolni az addig fel nem ismert CD-t, majd gluténmentes diéta mellett spontán fogantatásból 2011-ben egészséges gyermekük született. A gyermeknél gluténtartalmú diéta mellett az időszakosan elvégzett anti-tTG vizsgálat pozitivitást eddig nem jelzett. A szülőktől és a gyermektől nyert vér- és szövetminta (köldökzsinór és placenta) vizsgálatával a CD hátterében álló non-HLA-gének nemzetközi genetikai kutatásához tudtunk hozzájárulni. 


\section{Spermium elleni antitest a reproduktív elégtelenségek hátterében}

Nőbetegeinknél a sikertelen gyermekvállalás hátterében kórokként felmerülő a-sperm antitest vizsgálatát is elvégeztük.

Az a-sperm 49/500 (9,8 \%) esetben volt kimutatható. Közöttük 21/49 nőnél más antitest nem volt jelen, a további 28/49 betegnél viszont az a-sperm mellett auto-antitestek is észlelhetőek voltak.

Az a-sperm-pozitív betegeinknél alkalmazott prednisolonnal és néhány esetben ennek antikoaguláns kezeléssel történő kiegészítésével 19 fogantatás (2/19 AB, 16/19 szülés, $1 / 19$ jelenleg is zajló terhesség) következett be.

Az a-sperm nőkben hetero-antitest, azonban vizsgálatunk eredményei igazolták, hogy gyakran társul auto-antitestekkel (föként ANA, anti-dsDNA, anti-TPO, aPL-ek mellett észlelhetö), ezért sterilitás/infertilitás esetén az immunszupresszív kezelésnek létjogosultsága van.

Eredményeink rávilágítanak arra, hogy steril/infertilis párokat érdemes autoimmun betegségek, auto-antitestek irányába vizsgálni, hiszen ezek bizonyítása és megfelelő kezelése sikeres gyermekvállaláshoz vezethet. $\mathrm{PhD}$ munkánk eredményét mind magyar, mind nemzetközi szakfolyóiratban közöltük $(92,93,94,95,96)$, kezeléseink során 155 gyermek fogantatása történt meg sikerrel. Tudomásunk szerint a fenti témában elsőként közöltünk hazánkban. 


\section{REFERENCES}

1. P.J. Rowe, F.H. Comhaire, T.B. Hargreave, H.J. Mellows: WHO manual for the standard investigation and diagnosis of the infertile couple. Cambridge: Cambridge University Press; 1993.

2. L. Lampe, Z. Papp: Sterility and infertility. In: Lampé L, Papp Z, editors. Obstetrics and Gynecology 5th ed. Budapest: Semmelweis Publishing House; 65-67., 1992.

3. W. Zammiti, N. Mtiraoui, S. Hidar, M. Fekih, WY. Almawi, T. Mahjoub: Antibodies to $\beta 2$-glycoprotein I and annexin $\mathrm{V}$ in women with aerly and late idiopathic recurrent spontaneous abortions. Arch Gynecol Obstet, 274: 261-265., 2006.

4. P. Gergely: Antiphospholipid syndrome. In: Czirják L, editor. Clinical Immunology 1st ed. Budapest: Medicina Publishing House; 156-161., 2006.

5. D. Cohen, S.P. Berger, G.M. Steup-Beekman, K.W.M. Bloemenkamp, I.M. Bajerna: Diagnosis and management of the antiphospholipid syndrome. Br Med J, 340: 11251131., 2010.

6. S. Miyakis, M.D. Lockshin, T. Atsumi, D.W. Branch, R.L. Brey, R. Cervera, R.H.W.M. Derksen, P.G. De Groot, T. Koike, P.L. Meroni, G. Reber, Y. Shoenfeld, A. Tincani, P.G. Vlachoyiannopoulos, S.A. Krilis: International consensus statement on an update of the classification criteria for definite antiphospholipid syndrome (APS). J Thromb Haemost, 4: 295-306., 2006.

7. C. Solano, M. Lamuno, A. Vargas, L.M. Amezcua-Guerra: Comparison of the 1999 Sapporo and 2006 revised criteria for the classification of the antiphospholipid syndrome. Clin Exp Rheumatol, 27: 914-919., 2009.

8. M.D. Lockshin: Update on Antiphospholipid syndrome. Bull NYU Hosp Jt Dis, 66: 195-197., 2008.

9. Y. Sherer, Y. Shoenfeld: Anti-phospholipid antibodies - do they have a pathogenetic role in infertility? Scand J Rheumatol, 27 Suppl 107: 40-43., 1998.

10. E. Kiss: Antiphospholipid syndrome. In: Poor Gy, editor. Textbook of Rheumatology 1st ed. Budapest: Medicina Publishing House; 164-167., 2008.

11. N.S. Pattison, L.W. Chamley, M. Birdsall, A.M. Zanderigo, H.S. Liddell, J. McDougall: Does aspirin have a role in improving pregnancy outcome for women with the antiphospholipid syndrome? A randomized controlles trial. Am J Obstet Gynecol, 4: 1008-1012., 2000. 
12. M.D. Lockshin: Pregnancy loss and antiphospholipid antibodies. Lupus, 7 Suppl. 2: 86-89., 1998.

13. P. Szodoray, Gy. Bacsko, G. Lakos, M. Zeher: Combined treatment of a pregnant woman with antiphospholipid syndrome. Orv Hetil, 144: 2411-2413, 2003.

14. A. Pajor: Gravidity and obstetric immunology. In: Czirják L, editor: Clinical Immunology 1st ed. Budapest: Medicina Publishing House; 398-403., 2006.

15. R. Cervera, J. Balasch: Bidirectional effects on autoimmunity and reproduction. Hum Reprod Update, 14: 359-366., 2008.

16. N.S. Pattison, L.W. Chamley, M. Birdsall, A.M. Zanderigo, H.S. Liddell, J. McDougall: Does aspirin have a role in improving pregnancy outcome for women with the antiphospholipid syndrome? A randomized controlles trial. Am J Obstet Gynecol, 4: 1008-1012., 2000.

17. W. Zammiti, N. Mtiraoui, Ch. Kallel, E. Mercier, W.Y. Almawi, T. Mahjoub: A case-control study on the association of idiopathic recurrent pregnancy loss with autoantibodies against $\beta 2$-glycoprotein I and annexin V. Human Reprod, 131: 817822., 2006.

18. W. Zammiti, N. Mtiraoui, S. Hidar, M. Fekih, W.Y. Almawi, T. Mahjoub: Antibodies to $\beta 2$-glycoprotein I and annexin $\mathrm{V}$ in women with aerly and late idiopathic recurrent spontaneous abortions. Arch Gynecol Obstet, 274: 261-265., 2006.

19. P.L. Meroni, F. Tedesco, M. Locati, A. Vecchi, N. Di Simone, B. Acaia, S.S. Pierangeli, M.O. Borghi: Anti-phospholipid antibody mediated fetal loss: still an open question from a pathogenic point of view. Lupus, 19: 453-456., 2010.

20. M. Zeher: Systemic autoimmune diseases and gravidity. Magy Reumatol, 46: 7985., 2005.

21. K. Bramham, B.J. Hunt, S. Germain, I. Calatayud, M.K. Khamashta, S. Bewley, C. Nelson-Piercy: Pregnancy outcome in different clinical phenotypes of antiphospholipid syndrome. Lupus, 19: 58-64., 2010.

22. I. Marai, H. Carp, S. Shai, R. Shabo, G. Fishman, Y. Shoenfeld: Autoantibody panel screening in recurrent miscarriages. Am J Reprod Immunol, 51: 235-240., 2004.

23. V. Pengo: APS - controversies in diagnosis and management, critical overview of current guidelines. Thrombosis Research, 127: 51-52., 2011.

24. M. Rubinstein, A. Marazzi, E. Polak de Fried: Low-dose aspirin treatment improves ovarian responsiveness, uterine and ovarian blood flow velocity, implantation, and 
pregnancy rates in patients undergoing in vitro fertilization: a prospective, randomized, double-blind placebo-controlled assay. Fertil Steril, 5: 825-829., 1999.

25. R.G. Farquharson, S. Quenby, M. Greaves: Antiphospholipid Syndrome in Pregnancy: A Randomized, Controlled Trial of Treatment. Obstet Gynecol, 100: 408413., 2002.

26. R. Rai, H. Cohen, M. Dave, I. Regan: Randomised controlled trial of aspirin and aspirin plus heparin in pregnant women with ercurrent miscarriage associated with phospholipid antibodies (or antiphospholipid antibodies). Br Med J, 314: 253-257., 1997.

27. W.H. Kutteh: Antiphospholipid antibody-associated recurrent pregnancy loss: Treatment with heparin and low-dose aspirin is superior to low-dose aspirin alone. Am $\mathrm{J}$ Obstet Gynecol, 174: 1584-1589., 1996.

28. A. Mak, M.W. Cheung, A.A. Cheak, R.C. Ho: Combination of heparin and aspirin is superior to aspirin alone in enhancing live births in patients with recurrent pregnancy loss and positive anti-phospholipid antibodies: a meta-analysis of randomized controlled trials and meta-regression. Rheumatology (Oxford), 49: 281-288., 2010.

29. G. Girardi, P. Redecha, J.E. Salmon: Heparin prevents antiphospholipid antibodyinduced fetal loss by inhibiting complement activation. Nat Med, 10: 1222-1226., 2004. 30. M.D. Stephenson, P.J. Ballem, P. Tsang: Treatment of antiphospholipid antibody syndrome (APS) in pregnancy: a randomized pilot trial comparing low molecular weight heparin to unfractionated heparin. J Obstet Cynaecol Can, 26: 729-734., 2004.

31. G. Ruiz-Irastorza, M. Crowther, W. Branch, M.A. Khamashta: Antiphospholipid syndrome. Lancet, 376: 1498-1509., 2010.

32. I. Hasegawa, Y. Yamanoto, M. Suzuki, H. Murakawa, T. Kurabayashi, K. Takakuwa, K. Tanaka: Prednisolone plus low-dose aspirin improves the implantation rate in women with autoimmune conditions who are undergoing in vitro fertilization. Fertil Steril, 6: 1044-1048., 1998.

33. A. Sullivan, D.W. Branch: How to treat the antiphospholipid syndrome in pregnancy? Nőgyógyászati és Szülészeti Továbbképző Szemle, 3:159-167., 2002.

34. G. Triolo, A. Ferrante, F. Ciccia, A. Accardo-Palumbo, A. Perino, A. Castelli, A. Giarratano, G. Licata: Randomized study of subcutaneous low molecular weight heparin plus aspirin versus intravenous immunglobulin in the treatment of recurrent fetal loss associated with antiphospholipid antibodies. Arth Rheum, 3: 728-731., 2003. 
35. J. Foldesi, G. Winkler: Hypothyreosis and gravidity. Magy Belorv Arch, 61: 441451., 2008.

36. M. Arajoki, V. Jokimaa, A. Juuti, R. Koskinen, K. Irjala, L. Antila: Hypothyroidism among infertile women in Finland. Gynecol Endocrinol, 10: 127-131., 2000.

37. D. Glinoer: The regulation of thyroid function in pregnancy: Pathways of endocrine adaptation from physiology to pathology. Endocr Rev, 18: 404-433., 1997.

38. K. Poppe, D. Glinoer, A. Van Streirteghen, H. Tournaye, P. Devroey, J. Schiettercatte, B. Valkeniers: Thyroid dysfunction and autoimmunity in infertile women. Thyroid, 12: 997-1001., 2002.

39. R. Negro, G. Formoso, T. Mangieri, A. Pezzarossa, D. Dazzi, H. Hassan: Levothyroxine treatment in euthyroid pregnant women with autoimmune thyroid disease. Effects on obstetrical complications. J Clin Endocrinol Metab, 91: 2587-2591., 2006.

40. R.Z. Klein, J.E. Haddow, J.D. Faix, R.S. Brown, R.J. Hermos, A. Paulkinen: Prevalence of thyroid deficiency in pregnant women. Clin Endocrinol, 35: 41-46., 1991. 41. S.H. La Franchi, J.E. Haddow, J.G. Hollowell: Is thyroid inadequacy during gestation a risk factor for adverse pregnancy and developmental outcomes? Thyroid, 15: 60-71., 2005.

42. A. Stagnaro-Green, X. Chen, J.D. Boyden, T.F. Davies, Th. Scholl: The thyroid and pregnancy: A novel risk factor for very preterm delivery. Thyroid, 15: 351-357. 2005.

43. B.M. Casey, J.S. Dashe, C.E. Wells, J.J. Leveno, F.G. Cunningham: Subclinical hypothyroidism and pregnancy. Obstet Gynecol, 105: 239-245., 2005.

44. A. Stagnaro-Green, S.H. Roman, R.H. Cobin, E. Herazy, M. Alvarez-Marfany, T.F. Davies: Detection of at-risk pregnancy by means of highly sensitive assay for thyroid antibodies. JAMA, 264: 1422-1425., 1990.

45. D. Glinoer, M.F. Soto, P. Bordoux, B. Lejeune, F. Delange, M. Lemone, C. Robijn, J.P. Grun, P. de Nayer: Pregnancy in patients with mild thyroid abnormalities. J Clin Endocrinol Metab, 73: 421-427., 1991.

46. J.E. Haddow, G.E. Palomaki, W.C. Allan, J.R. Williams, G.J. Knight, J. Gagnow, C.E. O’Heir, M.I. Mitchell, R.J. Hermos, J.D. Faix, R.Z. Klein: Maternal thyroid deficiency during pregnancy and subsequent neuropsychological development. N Eng J Med, 341: 549-555., 1999.

47. R.C. Smallridge, P.W. Ladenson: Hypothyroidism and pregnancy (consequences to neonatal health). J Clin Endocrinol Metab, 86: 2349-2353., 2001. 
48. F. Vermiglio, V.P. Presti, M. Moleti, M. Sidoti, G. Tortorella, G. Scattido: Attention deficit and hyperactivity disorders in the offspring of mothers exposed to mild-moderate iodine deficiency disorder in developed countries. J Clin Endocrinol Metab, 89: 60546060., 2004.

49. M.I. Surks, E Ortiz, G.H. Daniels, C.T. Sawin, N.F. Col, R.N. Cobin, J.A. Franklyn, J.M. Hershman, K.D. Burman, M. Denke, C. Gorman, R.S. Cooper, N.J. Weisman: Subclinical thyroid disease. Scientific review and guidelines for diagnosis and management. JAMA, 291: 228-238., 2004.

50. H. Gharib, R.M. Tuttle, H.J. Baskin, L.H. Fisch, P.A. Singer, M.T. McDermot: Consensus statement: Subclinical thyroid dysfunction: A joint statement on management from the American Association of Clinical Endocrinologists, the American Thyroid Association and the Endocrine Society. J Clin Endocrinol Metab, 90: 581-585., 2005 .

51. J.G. Hollowell, S.H. La Franchi, R.C. Smallridge, C.Y. Spong, J.E. Haddow, C.A. Boyle: Summary of working group discussions on thyroid function and gestational outcomes. Thyroid, 15: 72-76., 2005.

52. M.J. Surks: Commentary: Subclinical thyroid dysfunction: A joint statement on management from the American Association of Clinical Endocrinologists, the American Thyroid Association and the Endocrine Society. J Clin Endocrinol Metab 90: 586-587., 2005 .

53. G. Suto: Celiac disease. In: Czirják L. Clinical Immunology 1st ed. Budapest: Medicina Publishing House; 325-326., 2006.

54. P. Collin, S. Vilska, P.K. Heinonen, O. Hallström, P. Pikkarainen: Infertility and coeliac disease. Gut, 39: 382-384., 1996.

55. C.Ciacci, M. Cirillo, G. Auriemma, G. Di Dato, F. Sabbatini, G. Mazzacca: Celiac Disease and Pregnancy Outcome. Am J Gastroenterol, 91: 718-722., 1996.

56. R. Ferguson, G.K.T. Holmes, W.T. Cooke: Coeliac disease, fertility and pregnancy. Scand J Gastroenterol, 17: 65-68., 1982.

57. K.L. Kolho, A. Tiitinem, M. Tulppala, L. Unkila-Kallio, E. Savilahti: Screening for coeliac disease in women with a history of recurrent miscarriage or infertility. $\mathrm{Br} \mathrm{J}$ Obstet Gynaecol, 106: 171-173., 1999.

58. N. Molteni, M.T. Bargella, P.A. Binchi: Obstetric and gynecological problems with untreated sprue. J Clin Gastroenterol, 12: 37-39., 1990. 
59. A.D.R. Ogborn: Pregnancy in patients with coeliac disease. Br J Obstet Gynecol, 82: 293-296., 1975.

60. K.S. Sher, J.F. Mayberry: Female fertility, obstetric and gynaecological history in coeliac disease. Digestion, 55: 243-246., 1994.

61. C.J.R. Goddard, H.R. Gillett: Complications of coeliac disease: are all patients at risk? Post Grad Med J, 82: 705-712., 2006.

62. A. Ferguson, E. Arranz, S. O’Mahony: Clinical and pathological spectrum of celiac disease - active, silent, latent, potential. Gut, 34: 150-151., 1993.

63. R. Eliakim, D.M. Sherer: Celiac Disease: Fertility and Pregnancy. Gynecol Obstet Invest, 51: 3-7., 2001.

64. P. Martinelli, R. Troncone, F. Paparo, P. Torre, E. Trapanese, C. Fasano, A. Lamberti, G. Budillon, G. Nardone, L. Greco: Coeliac disease and unfavourable outcome of pregnancy. Gut, 46: 332-335., 2000.

65. R. Pope, E. Sheiner: Celiac disease during pregnancy: to screen or not to screen? Arch Gynecol Obstet, 279: 1-3., 2009.

66. G.F. Meloni, S. Dessole, N. Vargiu, P.A. Tomasi, S. Musumeci: The prevalence of coeliac disease in infertility. Hum Reprod, 14: 2759-2761., 1999.

67. J.E. Jackson, M. Rosen, T. McLean, J. Moro, M. Croughan, M.I. Cedars: Prevalence of celiac disease in a cohort of women with unexplained infertility. Fertil Steril, 89: 1002-1004., 2008.

68. C. Hirson: Coeliac infertility - Folic acid therapy. Lancet, 295: 412., 1970.

69. L. Greco, A. Veneziano, L. Di Donato, C. Zampella, M. Pecoraro, D. Paladini: Undiagnosed celiac disease does not appear to be associated with unfavourable outcome of pregnancy. Gut, 53: 149-151., 2004.

70. W. Dickey, F. Stewart, J. Nelson: Screening for coeliac disease as a possible maternal risk factor for neural tube defect. Clin Genet, 49: 106-108., 1996.

71. J.F. Ludvigsson, J. Ludvigsson: Coeliac disease in the father affects the newborn. Gut, 49: 169-175., 2001.

72. S. Norgard, K. Fonager, H.T. Sorensen, J. Olsen: Birth outcomes of women with celiac disease: A nationwide historical cohort study. Am J Gastroenterol, 94: 24352440., 1999.

73. E. Sheiner, R. Peleg, A. Levy: Pregnancy outcome of patients known celiac disease. Eur J Obstet Gynecol Reprod Biol, 129: 41-45., 2006. 
74. P.G. Baker, A.E. Read: Reversible infertility in male coeliac disease. Br Med J, 2: 316-317., 1975.

75. M.J.G. Farthing, C.R.W. Edwards, L.H. Rees, A.M. Dawson: Male gonadal function in coeliac disease: 1. Sexual dysfunction, infertility, and semen quality. Gut, 23: 608614., 1982.

76. L. Greco: The father figure in coeliac disease. Gut, 46: 163., 2001.

77. P. Revesz: Detection of sperm antibodies in infertile couples by the ELISA method. Magy Nőorv L, 56: 337-345., 1993.

78. A. El-Roeiy, G. Valesini, J. Friberg, Y.S. Shoenfeld, R.C. Kennedy, A. Tincani, G. Balestrieri, N. Gleicher: Autoantibodies and common idiotypes in men and women with sperm antibodies. Am J Obstet Gynecol, 158: 596-603., 1988.

79. R. Bronson, G. Cooper, D. Rosenfeld: Sperm antibodies: their role in infertility. Fertil Steril, 42: 171-181., 1984.

80. G.G. Haas, K. Kubota, J.F. Queebman, A. Jijon, A.C. Menge, A.E. Beer: Circulating anti-sperm antibodies in recurrently aborting women. Fertil Steril, 45: 209215., 1986.

81. J.L. Yovich, J.D. Stanger, D. Kay, B. Boettcher: In vitro fertilisation of oocytes from women with serum anti-sperm antibodies. Lancet, 1: 369., 1984.

82. A. El-Roeiy, N. Gleicher, E. Confino, J. Friberg, A. Dudkiewicz: Presence of autoantibodies in follicular fluid and effect on in vitro fertilization. Obstet Gynecol, 70: 163-170., 1987.

83. B. Nagy, R. Gimes, J. Inovay, Gy. Szendei, T. Pulay, A. Czuppon: Detection of sperm antibodies in donor inseminated women. Magy Nőorv L 53: 52-54., 1990.

84. Gy. Perkedi, I. Rakoczi, J. demeter, Gy. Juhasz, I. Gati: Treatment of infertility caused by sperm antibodies. Magy Nőorv L 53: 55-57., 1990.

85. N. Gleicher, A. El-Roeiy, E. Confino, J. Friberg: Is endometriosis an autoimmune disease? Obstet Gynecol, 70: 115-122., 1987.

86. Z. Marcus, E.V. Hess: Antisperm antibodies in patients with systemic lupus erythematosus. Arth Rheum, 24: 569-570., 1981.

87. Y.S. Shoenfeld, D.A. Isenberg, J. Rauch, M.P. Madio, B.D. Stollar, R.S. Schwartz: Idiotypic cross-reactions of monoclonal human lupus autoantibodies. J Exp Med, 158: 718-730., 1983.

88. N.J. Alexander, J.H. Sampson, D.C. Fulgham: Pregnancy rates in patients treated for anti-sperm antibodies with prednisolone. Int J Fertil, 28: 63., 1983. 
89. M. Katz, R. Newill: Steroid treatment for infertility associated with anti-sperm antibodies. Lancet, 3: 1306., 1980.

90. S.C. Smarr, R. Wing, M.G. Hammond: Effect of steroid therapy on infertile couples with anti-sperm antibodies. Am J Obstet Gynecol, 158: 969., 1988.

91. K.L. Harrison, J.F. Henessy: Treatment of male sperm autoimmunity by in vitro fertilisation with washed spermatozoa. Med J Aust, 141: 598., 1984.

92. M. Kovacs, M. Hartwig, M. Aleksza, M. Tihanyi, T. Nagy, Gy. Vajda., J. Daru, B. Gasztonyi: Antiphospholipid antibodies in relation to sterility/infertility. Human Immunology, 73: 726-731., 2012.

93. M. Kovacs, A. Farkas, A. Gyorkos, M. Hartwig, M. Aleksza, M. Tihanyi, T. Nag, B. Gasztonyi: Antibodies and autoimmune diseases present in sterile and infertile females. Magyar Belorv. Arch., 61. (5): 395-399., 2008.

94. M. Kovacs, M. Hartwig, M. Aleksza, M. Tihanyi, T. Nagy, B. Gasztonyi: Searching for autoimmune diseases in sterile/infertile couples. Magyar Reumatol., 50. (4): 196202., 2009.

95. M. Kovacs, M. Szenes, T. Horvath, Gy. Vajda, B. Gasztonyi: Celiac disease in the background of reproductive disorders. Magyar Belorv. Arch., 64. (4): 225-230., 2011. 96. M. Kovacs, M. Szenes, T. Horvath, Gy. Vajda, B. Gasztonyi, Gy. Bartfai: Celiac disease as potential obstacle to childbearing. OJOG, 4., 2014., accepted 